\title{
Total Synthesis of Leucascandrolide A: A New
}

\section{Application of the Mukaiyama Aldol-Prins Reaction}

Lori J. Van Orden, Brian D. Patterson, and Scott D. Rychnovsky*

Department of Chemistry, 1102 Natural Sciences II, University of California-Irvine, Irvine, California 92697.

\section{Supporting Information}

1. General Experimental Details $\quad$ S2

2. Experimental Procedures $\quad$ S4

(3S, 4R)-3-Methyl-6-triisopropylsilyloxy-1-hexen-4-ol (15) S4

$\begin{array}{ll}\text { Acrylate } 17 & \text { S5 }\end{array}$

$\begin{array}{ll}\text { Lactone } \mathbf{1 8} & \text { S6 }\end{array}$

$\begin{array}{ll}\text { Acetoxy ether } \mathbf{1 3} & \text { S7 }\end{array}$

$\begin{array}{ll}\text { Silyl enol ether } \mathbf{1 4} & \text { S9 }\end{array}$

$\begin{array}{ll}\text { Tetrahydropyran } 19 & \text { S10 }\end{array}$

$\begin{array}{ll}\text { Allylic alcohols } \mathbf{2 0} \text { and } \mathbf{2 1} & \text { S11 }\end{array}$

Mosher's ester derivative of $\mathbf{2 0}$ (representative procedure) S12

Mosher ester of alcohol 20 (analysis) $\quad$ S13

$\begin{array}{ll}\text { TIPS-bis-protected diol } \mathbf{2 3} & \text { S14 }\end{array}$

$\begin{array}{ll}\text { Alcohol from } 23 & \text { S15 }\end{array}$

3-Vinyloxyhex-5-enoic acid ethyl ester (12a) $\quad$ S16 
9:1 Titanium tetrabromide/titanium tetraisopropoxide mixed Lewis acid (a representative procedure)

MAP products $\mathbf{1 0 a}$ and $\mathbf{2 4 a}$

Acetal 27

Ester 28a

Methyl ether $\mathbf{2 8 b}$

Methyl ether $\mathbf{5 5}$

Alcohol 29 S25

Aldehyde from 29 S26

Carboxylic acid from 29 S27

Seco acid $\mathbf{3 0}$ S29

Side chain aldehyde $\mathbf{3 3}$ S30

Side chain carboxylic acid $\mathbf{3 4}$ S30

Cesium 2-(phenylselenyl)acetate (41)

Cesium 2-((bis(2,2,2-trifluoroethoxy)phosphoryl) acetate (42)

Cesium but-2-ynoate (43)

Macrocyclic $\alpha$-selenyl ester $\left(\mathbf{3 8}, \mathbf{R}=\mathbf{C H}_{2} \mathbf{S e P h}\right)$

References and Notes

Proton and Carbon NMR Spectra

1. General Experimental Details. All reactions were carried out under an inert atmosphere of argon using flame or oven dried glassware and standard syringe and septa techniques. Concentrations were performed under reduced pressure with a rotary evaporator. Diethyl ether, toluene, tetrahydrofuran (THF), hexane, dimethylformamide 
(DMF), and dichloromethane were degassed and dried over activated alumina according to the procedure described by Grubbs. ${ }^{1}$ Column chromatography was performed using a forced flow of the indicated solvent system with 230-400 mesh silica gel. ${ }^{2}$ Thin layer chromatography (TLC) was performed on $250 \mu \mathrm{m}$ layer silica gel plates and developed plates were visualized by UV light, cerric ammonium molybdate, potassium permanganate or with $p$-anisaldehyde. When noted, solvents were degassed by passing a steady stream of argon through the dry solvent for $30 \mathrm{~min}$ prior to using or by freezing the solvent and evacuating the head space $(\sim 0.2$ Torr $)$ and allowing the solvent to melt under static vacuum (three cycles). All water used was deionized. Acryloyl chloride and titanium tetraisopropoxide $\left(\mathrm{Ti}(\mathrm{O} i \mathrm{Pr})_{4}\right)$ were distilled neat under argon at atmospheric pressure. Triethylamine, diisopropylamine, 2,6-lutidine, acetonitrile, benzene, 1,2dichloroethane, diisopropylethylamine, and pyridine were distilled from calcium hydride under nitrogen or argon at atmospheric pressure. Acetic anhydride was distilled from phosphorous pentoxide under argon at atmospheric pressure. Dess-Martin periodinane and 2,6-di-tert-butyl-4-methylpyridine (2,6-DBMP) were prepared in house., ${ }^{3,4}$ Titanium tetrabromide was purchased as a solid in an ampule only from Strem and tin tetrabromide was purchased from Aldrich. Both solutions of these Lewis acids were prepared in a recirculating glovebox with degassed, anhydrous dichloromethane. The solution of titanium tetrachloride was prepared under an argon atmosphere from a fresh bottle of the neat Lewis acid and anhydrous dichloromethane. ${ }^{1} \mathrm{H}$ NMR spectra were reported in ppm relative to residual solvent signals. Data are presented as follows: chemical shift, multiplicity $(\mathrm{s}=$ singlet, $\mathrm{d}=$ doublet, $\mathrm{t}=$ triplet, $\mathrm{q}=$ quartet, $\mathrm{br}=$ broad $)$, coupling constant(s) in Hertz $(\mathrm{Hz})$, and integration. Multiplets $(\mathrm{m})$ are reported over the range 
(ppm) at which they appear. ${ }^{13} \mathrm{C}$ NMR spectra were reported in ppm relative to residual solvent signals. For the cases where $\mathrm{D}_{2} \mathrm{O}$ was used, referencing was performed in the ${ }^{1} \mathrm{H}$ NMR acquisition of the sample, which immediately preceded the ${ }^{13} \mathrm{C}$ acquisition. Concentration for optical rotations (c) is reported as $\mathrm{g} / 100 \mathrm{~mL}$.

\section{Experimental Procedures}

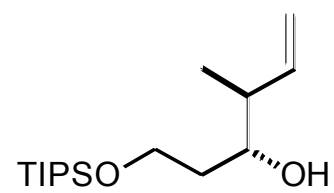

15

(3S, 4R)-3-Methyl-6-triisopropylsilyloxy-1-hexen-4-ol (15). ${ }^{5}$ A solution of potassium tert-butoxide (7.33 g, $65.4 \mathrm{mmol}, 0.91$ equiv) in anhydrous THF (60 mL) was cooled to $-78{ }^{\circ} \mathrm{C}$. Condensed trans-2-butene $(13 \mathrm{~mL})$ was then added dropwise by cannula, followed by the dropwise addition of $n$-butyllithium as a solution in hexane $(26.4 \mathrm{~mL}, 2.5$ M, $66.1 \mathrm{mmol}, 0.92$ equiv). The resultant orange, viscous solution was allowed to warm to $-45{ }^{\circ} \mathrm{C}$ and was stirred for ten minutes. The mixture was then cooled to $-78{ }^{\circ} \mathrm{C}$ and (-)-diisopinocampheylborane $(25.0 \mathrm{~g}, 79.0 \mathrm{mmol}, 1.1$ equiv) as a solution in degassed, anhydrous diethyl ether $(86 \mathrm{~mL})$ was then added dropwise, upon which, the solution became colorless. After stirring for $30 \mathrm{~min}$ at $-78{ }^{\circ} \mathrm{C}$, boron trifluoride etherate $(10.9$ $\mathrm{mL}, 86.2 \mathrm{mmol}, 1.2$ equiv) was added dropwise, followed by the addition of 3triisopropylsiloxypropanal (16.6 $\mathrm{g}, 71.8 \mathrm{mmol}, 1.0$ equiv) as a solution in anhydrous diethyl ether $(260 \mathrm{~mL})$. The pale yellow solution was stirred at $-78^{\circ} \mathrm{C}$ for $39 \mathrm{~h}$ and was 
then allowed to warm slowly to $-35^{\circ} \mathrm{C}$. A solution of sodium hydroxide $(5.8 \mathrm{~g}$ in $50 \mathrm{~mL}$ water) was added, followed by the addition of hydrogen peroxide (30 mL, $30 \%$ in water). The resulting solution was allowed to warm to $23{ }^{\circ} \mathrm{C}$ and stir for $24 \mathrm{~h}$. Concentration in vacuo provided a crude oil which was dissolved in methanol $(800 \mathrm{~mL})$. Sodium borohydride $(0.80 \mathrm{~g})$ was added and the mixture was stirred for one hour. A dilution with diethyl ether $(50 \mathrm{~mL})$ and water $(50 \mathrm{~mL})$ provided a biphasic mixture which was separated. The aqueous layer was extracted with diethyl ether $(3 \times 300 \mathrm{~mL})$ and the combined organic layers were dried over anhydrous sodium sulfate and concentrated in vacuo. The crude oil was purified by flash chromatography (0-15\% diethyl ether/hexanes) to yield $10.6 \mathrm{~g}(56 \%, 92 \%$ ee $)$ of $\mathbf{1 5}$ as a clear, colorless oil: $[\alpha]^{21}{ }_{D}-6.3(c$ $=1.0$, dichloromethane); IR (neat) 3509, 2943, 2867, $1090 \mathrm{~cm}^{-1} ;{ }^{1} \mathrm{H}$ NMR $(500 \mathrm{MHz}$, $\left.\mathrm{CDCl}_{3}\right) \delta 5.86(\mathrm{ddd}, J=17.7,9.8,7.8,1 \mathrm{H}), 5.10-5.06(\mathrm{~m}, 2 \mathrm{H}), 4.00(\mathrm{dt}, J=9.8,4.6$, $1 \mathrm{H}), 3.90(\mathrm{td}, J=9.5,3.9,1 \mathrm{H}), 3.75(\mathrm{ddd}, J=8.3,5.4,2.4,1 \mathrm{H}), 3.44$ (br s, $1 \mathrm{H}), 2.27$ (dq, $J=13.4,6.8,1 \mathrm{H}), 1.74-1.58(\mathrm{~m}, 2 \mathrm{H}), 1.10-1.04(\mathrm{~m}, 24 \mathrm{H}) ;{ }^{13} \mathrm{C} \mathrm{NMR}\left(125 \mathrm{MHz}, \mathrm{CDCl}_{3}\right)$

$\delta$ 141.0, 115.2, 75.6, 63.6, 44.1, 35.7, 18.2, 15.9, 12.0; HRMS (ESI), calcd for $\mathrm{C}_{16} \mathrm{H}_{34} \mathrm{O}_{2} \mathrm{SiNa}[\mathrm{M}+\mathrm{Na}]^{+}$309.2226, found 309.2232.

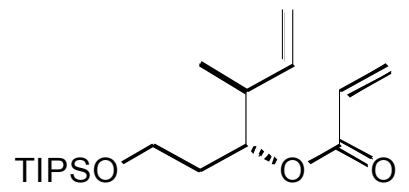

17

Acrylate 17. To a solution of alcohol $15(25.0 \mathrm{mg}, 0.087 \mathrm{mmol}, 1.0$ equiv) in anhydrous dichloromethane $(1.0 \mathrm{~mL})$ were added triethylamine $(24.0 \mu \mathrm{L}, 0.175 \mathrm{mmol}$, 2.0 equiv) and 4-dimethylaminopyridine ( $1.0 \mathrm{mg}, 0.002 \mathrm{mmol}, 0.02$ equiv). The solution 
was cooled to $0{ }^{\circ} \mathrm{C}$ and acryloyl chloride $(8.5 \mu \mathrm{L}, 9.75 \mathrm{mmol}, 1.2$ equiv) was added dropwise. The resultant solution was stirred for 25 min then saturated aqueous sodium bicarbonate $(2 \mathrm{~mL})$ was added and the mixture was allowed to warm to $23{ }^{\circ} \mathrm{C}$. After stirring for $15 \mathrm{~min}$, the layers were separated and the aqueous layer was extracted with dichloromethane $(3 \times 5 \mathrm{~mL})$. The combined organic layers were washed with water $(2 \times$ $5 \mathrm{~mL})$ and brine $(1 \times 5 \mathrm{~mL})$, then dried over anhydrous magnesium sulfate and concentrated in vacuo. The crude oil was purified by flash chromatography (0-5\% diethyl ether/hexanes) to yield $30.0 \mathrm{mg}(87 \%)$ of $\mathbf{1 7}$ as a clear, colorless oil: $[\alpha]^{24}{ }_{\mathrm{D}}+22.2$ $\left(c=1.00\right.$, chloroform); IR (neat) 2944, 2868, 1728, 1193, $883 \mathrm{~cm}^{-1} ;{ }^{1} \mathrm{H}$ NMR $(500 \mathrm{MHz}$, $\left.\mathrm{C}_{6} \mathrm{D}_{6}\right) \delta 6.29(\mathrm{dd}, J=17.2,1.4,1 \mathrm{H}), 6.01(\mathrm{dd}, J=17.4,10.6,1 \mathrm{H}), 5.71(\mathrm{dd}, J=10.4,1.6$, $1 \mathrm{H}), 5.67(\mathrm{ddd}, J=18.6,10.8,7.8,1 \mathrm{H}), 5.00-4.96(\mathrm{~m}, 2 \mathrm{H}), 4.94(\mathrm{~d}, J=1.0,1 \mathrm{H}), 3.61(\mathrm{t}$, $J=6.8,2 \mathrm{H}), 2.47-2.37(\mathrm{~m}, 1 \mathrm{H}), 1.75-1.68(\mathrm{~m}, 2 \mathrm{H}), 0.97-0.91(\mathrm{~m}, 24 \mathrm{H}) ;{ }^{13} \mathrm{C}$ NMR $(125$ $\left.\mathrm{MHz}, \mathrm{C}_{6} \mathrm{D}_{6}\right) \delta 165.4,139.8,130.0,129.2,115.6,74.4,60.4,41.1,35.1,18.3,15.9,12.3$; HRMS (EI), calcd for $\mathrm{C}_{15} \mathrm{H}_{29} \mathrm{O}_{3} \mathrm{Si}$ [M - isobutylene] $]^{+} 285.1886$, found 285.1888 .

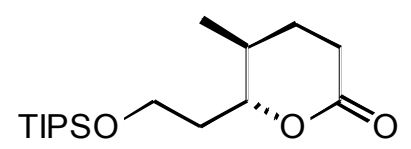

18

Lactone 18. To a solution of acrylate $17(0.76 \mathrm{~g}, 2.2 \mathrm{mmol}, 1.0$ equiv) in anhydrous, degassed 1,2-dichloroethane (45 mL) was added Grubbs' 2nd generation ruthenium catalyst $^{6}$ (47.0 mg, $0.056 \mathrm{mmol}, 0.03$ equiv). The solution was heated at reflux for two hours then another equal portion of the catalyst $(47.0 \mathrm{mg}, 0.056 \mathrm{mmol}, 0.03$ equiv) was 
added. After heating at reflux for an additional 90 min, the dark brown solution was allowed to cool to $23{ }^{\circ} \mathrm{C}$. The open reaction vessel was quickly transferred to a Parr bomb, which was then pressurized with hydrogen gas (100 psi), and stirred vigorously for $16 \mathrm{~h}$. The reaction mixture was then concentrated in vacuo and purified by flash chromatography (10-40\% diethyl ether/hexanes) to afford $0.64 \mathrm{~g}(91 \%)$ of $\mathbf{1 8}$ as a clear, colorless oil: $[\alpha]^{22}{ }_{D}+63.7$ ( $c=1.00$, chloroform); IR (neat) 2943, 2868, 1742, $1094 \mathrm{~cm}^{-1}$; ${ }^{1} \mathrm{H}$ NMR $\left(500 \mathrm{MHz}, \mathrm{CDCl}_{3}\right) \delta 4.16(\mathrm{td}, J=10.4,2.4,1 \mathrm{H}), 3.94-3.84(\mathrm{~m}, 2 \mathrm{H}), 2.61$ (ddd, $J=17.7,6.8,4.8,1 \mathrm{H}), 2.47(\mathrm{ddd}, J=17.7,9.6,6.0,1 \mathrm{H}), 1.95(\mathrm{dddd}, J=14.5,8.6,6.3$, 2.4, 1H), $1.92(\mathrm{ddt}, J=13.4,6.9,4.8,1 \mathrm{H}), 1.82-1.70(\mathrm{~m}, 2 \mathrm{H}), 1.61-1.52(\mathrm{~m}, 1 \mathrm{H})$, 1.07-1.03 (m, 24H); ${ }^{13} \mathrm{C}$ NMR (125 MHz, $\left.\mathrm{CDCl}_{3}\right) \delta$ 171.9, 82.9, 59.1, 37.1, 32.7, 29.7, 28.0, 18.2, 17.7, 12.1; HRMS (EI), calcd for $\mathrm{C}_{14} \mathrm{H}_{27} \mathrm{O}_{3} \mathrm{Si}[\mathrm{M}-i \operatorname{Pr}]^{+} 271.1729$, found 271.1733 .

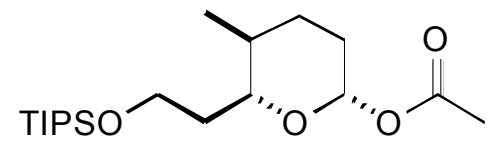

Acetoxy ether 13. To a solution of lactone 18 (0.63 g, $2.00 \mathrm{mmol}, 1.0$ equiv) in anhydrous dichloromethane $(22 \mathrm{~mL})$ at $-78 \quad{ }^{\circ} \mathrm{C}$ was added a solution of diisobutylaluminum hydride in hexanes $(4.0 \mathrm{~mL}, 1.0 \mathrm{M}, 4.0 \mathrm{mmol}, 2.0$ equiv) dropwise down the side of the flask. The solution was stirred for 50 min then pyridine $(0.49 \mathrm{~mL}$, $6.0 \mathrm{mmol}, 3.0$ equiv) was added dropwise, followed by the addition of DMAP (0.73 $\mathrm{g}$, $6.0 \mathrm{mmol}, 3.0$ equiv) and acetic anhydride (1.13 mL, $12.0 \mathrm{mmol}, 6.0$ equiv). The solution was stirred for $14 \mathrm{~h}$ at $-78{ }^{\circ} \mathrm{C}$ then was slowly warmed to $-10{ }^{\circ} \mathrm{C}$. Saturated 
aqueous sodium potassium tartrate $(30 \mathrm{~mL})$ and saturated aqueous ammonium chloride $\left(30 \mathrm{~mL}\right.$ ) were added and the mixture was stirred vigorously at $23{ }^{\circ} \mathrm{C}$ for one hour. The layers were separated and the aqueous layer was extracted with dichloromethane (4 x 40 $\mathrm{mL}$ ). The combined organic layers were washed with a cold, aqueous $1 \mathrm{M}$ solution of sodium bisulfate $(1 \times 30 \mathrm{~mL})$ followed immediately by washes with saturated aqueous sodium bicarbonate $(3 \times 30 \mathrm{~mL})$ and brine $(1 \times 30 \mathrm{~mL})$. The organic layer was dried over anhydrous magnesium sulfate and concentrated in vacuo. The crude oil was purified by flash chromatography (0-8\% diethyl ether/hexanes) to afford $0.66 \mathrm{~g}(91 \%)$ of $\mathbf{1 3}$ as a clear, colorless oil with an 2,6-cis/trans diastereomeric ratio of $>95: 5$ (as determined by crude proton NMR spectroscopy): $[\alpha]_{\mathrm{D}}^{23}+27.1(c=1.00$, chloroform); IR (neat) 2943, $1759,1463,1047 \mathrm{~cm}^{-1} ;{ }^{1} \mathrm{H}$ NMR $\left(500 \mathrm{MHz}, \mathrm{C}_{6} \mathrm{D}_{6}\right) \delta 5.69(\mathrm{dd}, J=9.6,2.6,1 \mathrm{H}), 3.96$ (ddd, $J=9.7,8.3,5.9,1 \mathrm{H}), 3.87(\mathrm{ddd}, J=9.7,6.9,4.4,1 \mathrm{H}), 3.25$ (dd, $J=9.5,2.2,1 \mathrm{H}$ ), $1.93(\mathrm{dddd}, J=16.1,9.1,6.1,2.3,1 \mathrm{H}), 1.66(\mathrm{~s}, 3 \mathrm{H}), 1.66-1.61(\mathrm{~m}, 1 \mathrm{H}), 1.60-1.46(\mathrm{~m}$, $2 \mathrm{H}), 1.42(\mathrm{dq}, J=13.5,3.4,1 \mathrm{H}), 1.15-1.10(\mathrm{~m}, 21 \mathrm{H}), 0.96-0.83(\mathrm{~m}, 2 \mathrm{H}), 0.61(\mathrm{~d}, J=$ 6.6, 3H); ${ }^{13} \mathrm{C}$ NMR $\left(125 \mathrm{MHz}, \mathrm{C}_{6} \mathrm{D}_{6}\right) \delta 168.6,94.8,79.3,60.1,36.9,34.4,31.4,30.9$, 20.8, 18.3, 17.2, 12.4; HRMS (EI), calcd for $\mathrm{C}_{17} \mathrm{H}_{35} \mathrm{O}_{2} \mathrm{Si}[\mathrm{M}-\mathrm{OAc}]^{+}$299.2406, found 299.2412. 


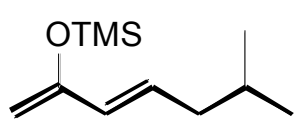

14

Silyl enol ether 14. ${ }^{7}$ A solution of diisopropylamine (2.22 mL, $15.6 \mathrm{mmol}, 2.0$ equiv) in anhydrous THF (40 mL) was cooled to $-78{ }^{\circ} \mathrm{C}$ and $n$-butyllithium, as a solution in hexanes (3.0 mL, 2.5 M, $23.8 \mathrm{mmol}, 3.0$ equiv), was added dropwise. After stirring for ten minutes, $(E)$-6-methylhept-3-en-2-one ${ }^{8}(1.0 \mathrm{~g}, 7.92 \mathrm{mmol}, 1.0$ equiv) was added dropwise as a solution in anhydrous THF $(15 \mathrm{~mL})$. The resultant solution was stirred for an additional $20 \mathrm{~min}$ then chlorotrimethylsilane $(3.0 \mathrm{~mL}, 23.8 \mathrm{mmol}, 3.0$ equiv) was added dropwise. The solution was then warmed to $0{ }^{\circ} \mathrm{C}$, and stirred for $40 \mathrm{~min}$. The reaction mixture was then poured into an aliquot of hexanes $(30 \mathrm{~mL})$ and washed with saturated aqueous sodium bicarbonate $(3 \times 30 \mathrm{~mL})$ and brine $(1 \times 30 \mathrm{~mL})$. The organic layer was dried over anhydrous sodium sulfate, and concentrated in vacuo. Bulb-to-bulb distillation of the crude organic material $\left(0.7\right.$ torr, $\left.35^{\circ} \mathrm{C}\right)$ afforded $1.47 \mathrm{~g}(93 \%)$ of $\mathbf{1 4}$ as a clear, colorless oil: ${ }^{1} \mathrm{H}$ NMR $\left(400 \mathrm{MHz}, \mathrm{C}_{6} \mathrm{D}_{6}\right) \delta 6.18(\mathrm{dt}, J=15.1,7.4,1 \mathrm{H}), 5.93(\mathrm{dt}, J$ $=15.1,1.3,1 \mathrm{H}), 4.35(\mathrm{~s}, 1 \mathrm{H}), 4.30(\mathrm{~s}, 1 \mathrm{H}), 1.92(\mathrm{td}, J=6.7,1.3,2 \mathrm{H}), 1.56$ (app. quintet, $J=6.8,1 \mathrm{H}), 0.85(\mathrm{~d}, J=6.6,6 \mathrm{H}), 0.17(\mathrm{~s}, 9 \mathrm{H})$. 


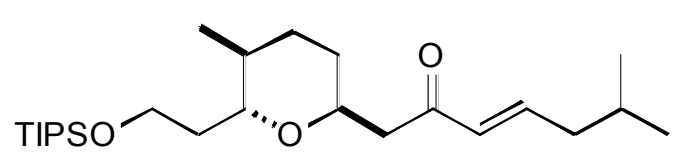

19

Tetrahydropyran 19. To a solution of acetoxy ether 13 ( $0.62 \mathrm{~g}, 1.79 \mathrm{mmol}, 1.0$ equiv) and silyl enol ether 14 (0.71 g, $3.58 \mathrm{mmol}, 2.0$ equiv) in anhydrous dichloromethane (18 $\mathrm{mL}$ ) was added zinc bromide ( $40.0 \mathrm{mg}, 0.179 \mathrm{mmol}, 0.1$ equiv). The slurry was stirred for four hours, then was concentrated in vacuo and immediately purified by flash chromatography (0-7\% diethyl ether/hexanes) to give $0.70 \mathrm{~g}(92 \%)$ of $\mathbf{1 9}$ as a clear, colorless oil with a 2,6-trans/cis diastereomeric ratio of $>95: 5$ (as determined by crude proton NMR spectroscopy): $[\alpha]_{D}^{23}+35.5(c=1.00$, chloroform); IR (neat) 2956,1673 , $1629,1463,1092,883 \mathrm{~cm}^{-1} ;{ }^{1} \mathrm{H}$ NMR $\left(500 \mathrm{MHz}, \mathrm{C}_{6} \mathrm{D}_{6}\right) \delta 6.72(\mathrm{dt}, J=15.8,7.4,1 \mathrm{H})$, $6.04(\mathrm{td}, J=15.8,1.4,1 \mathrm{H}), 4.39$ (app. quartet, $J=6.1,1 \mathrm{H}), 3.90(\mathrm{ddd}, J=7.7,6.4,2.6$, 2H), 3.54 (ddd, $J=9.6,6.4,3.3,1 \mathrm{H}), 2.83(\mathrm{dd}, J=15.0,7.1,1 \mathrm{H}), 2.43(\mathrm{dd}, J=15.0,6.4$, $1 \mathrm{H}), 1.95-1.87(\mathrm{~m}, 1 \mathrm{H}), 1.80(\mathrm{td}, J=7.5,3.3,1 \mathrm{H}), 1.77(\mathrm{td}, J=6.8,1.4,2 \mathrm{H}), 1.56-1.36$ (m, 4H), 1.34-1.26 (m, 1H), 1.14-1.18 (m, 24H), $0.88(\mathrm{~d}, J=6.8,3 \mathrm{H}), 0.75(\mathrm{~d}, J=6.7$, $6 \mathrm{H}) ;{ }^{13} \mathrm{C}$ NMR (125 MHz, $\left.\mathrm{C}_{6} \mathrm{D}_{6}\right) \delta 195.9,145.3,132.1,74.1,67.9,60.8,44.3,41.7,36.3$, 33.6, 28.1, 28.0, 26.8, 22.4, 18.5, 18.4, 12.4; HRMS (EI), calcd for $\mathrm{C}_{22} \mathrm{H}_{41} \mathrm{O}_{3} \mathrm{Si}[\mathrm{M}-i \mathrm{Pr}]^{+}$ 381.2825, found 381.2834; Anal. calcd for $\mathrm{C}_{25} \mathrm{H}_{48} \mathrm{O}_{3} \mathrm{Si}$ : C, 70.70; H, 11.39. Found: C, 70.90; H, 11.33 . 


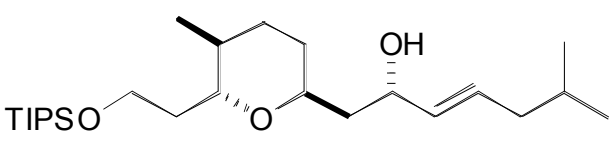

20

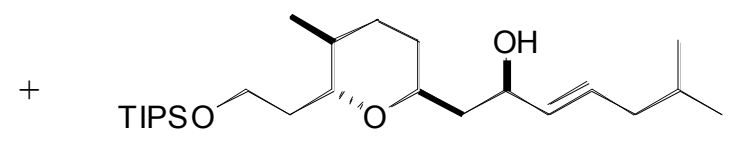

21

Allylic alcohols 20 and 21. To a solution of tetrahydropyran 19 (50.0 mg, 0.118 mmol, 1.0 equiv) in anhydrous toluene $(0.5 \mathrm{~mL})$ was added a freshly prepared solution of the (R)-CBS catalyst ${ }^{9}$ in toluene $\left(26.0 \mu \mathrm{L}, 0.68 \mathrm{M}, 0.15\right.$ equiv). After cooling to $0{ }^{\circ} \mathrm{C}$, borane dimethyl sulfide complex (17.0 $\mu \mathrm{L}, 0.18 \mathrm{mmol}, 1.5$ equiv) was added dropwise and the resultant solution was stirred for eight hours. Methanol $(2 \mathrm{~mL})$ was added then the mixture was allowed to warm to $23^{\circ} \mathrm{C}$ and was stirred for an additional ten minutes. Dilution with diethyl ether $(5 \mathrm{~mL})$ and water $(5 \mathrm{~mL})$ followed and the layers were separated. The aqueous layer was extracted with diethyl ether $(3 \times 5 \mathrm{~mL})$ and the combined organic layers were washed with water $(3 \times 5 \mathrm{~mL})$ and brine $(1 \times 5 \mathrm{~mL})$, dried over anhydrous magnesium sulfate, and concentrated in vacuo. The crude oil was shown to be a 15:1 diastereomeric ratio (as determined by proton NMR spectroscopy) and was purified by flash chromatography (5-40\% diethyl ether/hexanes) to provide $42.0 \mathrm{mg}$ $(83 \%)$ of 20 and $4 \mathrm{mg}(8.0 \%)$ of 21: Major diastereomer 20: $[\alpha]^{23}{ }_{\mathrm{D}}+38.8(c=0.50$, chloroform); IR (neat) 3448, 2943, 2867, 1463, $1097 \mathrm{~cm}^{-1} ;{ }^{1} \mathrm{H}$ NMR (500 MHz, $\mathrm{C}_{6} \mathrm{D}_{6}$ ) $\delta$ $5.82(\mathrm{dtd}, J=14.9,7.1,1.0,1 \mathrm{H}), 5.56(\mathrm{ddt}, J=15.2,6.1,1.2,1 \mathrm{H}), 4.37-4.32(\mathrm{~m}, 1 \mathrm{H})$, 3.92-3.87 (m, 2H), 3.85-3.79 (m, 1H), 3.57 (ddd, $J=9.3,5.7,3.6,1 \mathrm{H}), 3.07(\mathrm{~s}, 1 \mathrm{H})$, $2.02(\mathrm{ddd}, J=14.2,10.2,8.9,1 \mathrm{H}), 1.93(\mathrm{td}, J=7.1,2.9,2 \mathrm{H}), 1.89(\mathrm{ddt}, J=14.7,11.5$, $5.6,1 \mathrm{H}), 1.76(\mathrm{dtd}, J=17.4,7.6,3.4,1 \mathrm{H}), 1.60$ (app. septet, $J=6.7,1 \mathrm{H}), 1.44$ (ddd, $J=$ $17.0,6.8,4.1,1 \mathrm{H}), 1.37-1.22(\mathrm{~m}, 5 \mathrm{H}), 1.19-1.13(\mathrm{~m}, 21 \mathrm{H}), 0.90(\mathrm{~d}, J=6.6,3 \mathrm{H}), 0.90(\mathrm{~d}$, $J=6.6,3 \mathrm{H}), 0.86(\mathrm{~d}, J=6.8,3 \mathrm{H}) ;{ }^{13} \mathrm{C} \mathrm{NMR}\left(125 \mathrm{MHz}, \mathrm{C}_{6} \mathrm{D}_{6}\right) \delta 135.7,129.7,74.5,73.0$, 
71.8, 61.3, 42.6, 41.4, 36.8, 34.1, 29.3, 29.2, 27.1, 23.1, 23.0, 19.0, 13.0. HRMS (ESI), calcd for $\mathrm{C}_{25} \mathrm{H}_{50} \mathrm{O}_{3} \mathrm{SiNa}[\mathrm{M}+\mathrm{Na}]^{+}$449.3427, found 449.3438.

Minor diastereomer 21: $[\alpha]^{23}+33.6(c=0.44$, chloroform); IR (neat) 3434,2952 , 2867, 1463, $1095 \mathrm{~cm}^{-1} ;{ }^{1} \mathrm{H}$ NMR (500 MHz, $\left.\mathrm{C}_{6} \mathrm{D}_{6}\right) \delta 5.74(\mathrm{dtd}, J=15.2,6.8,1.0,1 \mathrm{H})$, $5.55(\mathrm{ddt}, J=15.1,5.9,1.2,1 \mathrm{H}), 4.46-4.39(\mathrm{~m}, 1 \mathrm{H}), 4.09(\mathrm{ddt}, J=9.5,5.9,4.2,1 \mathrm{H})$, $3.97-3.86(\mathrm{~m}, 2 \mathrm{H}), 3.59(\mathrm{ddd}, J=9.3,5.7,3.6,1 \mathrm{H}), 2.17(\mathrm{br} \mathrm{s}, 1 \mathrm{H}), 2.00-1.86(\mathrm{~m}, 4 \mathrm{H})$, $1.80(\mathrm{dtd}, J=14.7,7.3,3.4,1 \mathrm{H}), 1.59$ (app. septet, $J=6.6,1 \mathrm{H}), 1.49$ (ddd, $J=17.0,6.8$, 4.1, 1H), 1.42-1.30 (m, 5H), 1.18-1.13 (m, 21H), $0.90(\mathrm{~d}, J=6.6,6 \mathrm{H}), 0.89(\mathrm{~d}, J=6.6$, $3 \mathrm{H}) ;{ }^{13} \mathrm{C}$ NMR (125 MHz, $\left.\mathrm{C}_{6} \mathrm{D}_{6}\right) \delta$ 136.2, 129.5, 74.3, 70.2, 68.7, 61.4, 42.6, 41.0, 36.9, 34.1, 29.3, 28.9, 27.3, 23.1, 23.0, 19.1, 13.0. HRMS (ESI), calcd for $\mathrm{C}_{25} \mathrm{H}_{50} \mathrm{O}_{3} \mathrm{SiNa}[\mathrm{M}+$ $\mathrm{Na}]^{+} 449.3427$, found 449.3416 .

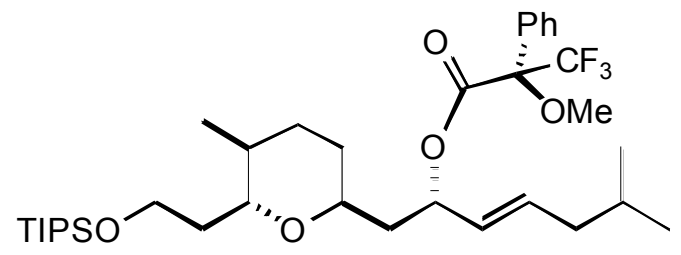

Mosher's ester derivative of 20 (representative procedure). ${ }^{10}$ To a solution of $(R)$ (+)- $\alpha$-methoxy- $\alpha$-(trifluoromethyl)phenylacetic acid ((R)-Mosher's acid) (15.0 mg, 0.059 mmol, 2.5 equiv) in anhydrous hexanes $(3.5 \mathrm{~mL})$ were added anhydrous DMF (4.6 $\mu \mathrm{L}$, $0.059 \mathrm{mmol}, 2.5$ equiv) and oxalyl chloride $(22.0 \mu \mathrm{L}, 0.259 \mathrm{mmol}, 11.3$ equiv). A precipitate formed immediately. After stirring for one hour, the reaction mixture was filtered through a cotton plug and the filtrate was concentrated in vacuo. The crude oil was redissolved in anhydrous dichloromethane $(1.0 \mathrm{~mL})$ and added to a solution of 
alcohol 20 (10.0 mg, $0.023 \mathrm{mmol}, 1.0$ equiv) and 4-dimethylaminopyridine (8.6 mg, $0.070 \mathrm{mmol}, 3.0$ equiv) in anhydrous dichloromethane $(2.0 \mathrm{~mL})$. This mixture was stirred for $13 \mathrm{~h}$ then diluted with saturated aqueous sodium bicarbonate $(2 \mathrm{~mL})$ and diethyl ether $(10 \mathrm{~mL})$. The layers were separated and the aqueous layer was extracted with diethyl ether $(3 \times 10 \mathrm{~mL})$. The combined organic layers were washed with $1 \mathrm{~N}$ sodium bisulfate $(1 \times 10 \mathrm{~mL})$, water $(1 \times 10 \mathrm{~mL})$, and brine $(1 \times 10 \mathrm{~mL})$ then dried over anhydrous sodium sulfate and concentrated in vacuo. The following analysis was performed on the crude material.

\section{Mosher ester of alcohol 20 (analysis).}

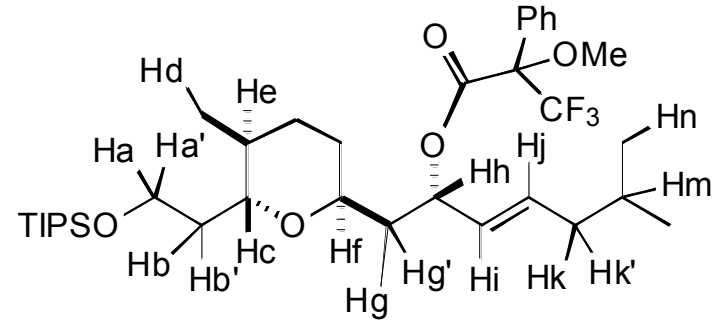

\begin{tabular}{llll}
\hline & $\delta(S, R)$ & $\delta(S, S)$ & $\delta(S, S)-\delta(S, R)$ \\
\hline $\mathbf{H a}, \mathbf{H a}$, & 4.010 & 4.021 & 0.011 \\
$\mathbf{H b}, \mathbf{H b}$, & 1.896 & 1.904 & 0.008 \\
$\mathbf{H c}$ & 3.548 & 3.545 & -0.003 \\
$\mathbf{H d}$ & 0.823 & 0.817 & -0.006 \\
$\mathbf{H e}$ & 1.313 & 1.302 & -0.011 \\
$\mathbf{H f}$ & 3.821 & 3.761 & -0.060 \\
$\mathbf{H g}$ & 2.327 & 2.304 & -0.023 \\
$\mathbf{H g}$, & 1.462 & 1.449 & -0.013 \\
$\mathbf{H h}$ & 5.751 & 5.773 & 0.022 \\
$\mathbf{H i}$ & 5.287 & 5.396 & 0.109 \\
$\mathbf{H j}$ & 5.896 & 5.948 & 0.053
\end{tabular}




$\begin{array}{llll}\mathbf{H k}, \mathbf{H k}{ }^{\prime} & 1.803 & 1.832 & 0.029 \\ \mathbf{H m} & 1.536 & 1.543 & 0.007 \\ \mathbf{H n} & 0.837 & 0.840 & 0.003\end{array}$

Positive values for $\Delta \delta$ means that the signal is shifted downfield and negative values for $\Delta \delta$ means that the signal is shifted upfield from that of the other diastereomeric ester.

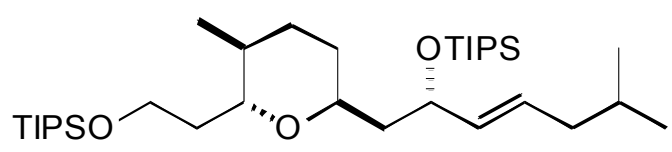

23

TIPS-bis-protected diol 23. To a solution of allylic alcohol $20(0.15 \mathrm{~g}, 0.351 \mathrm{mmol}$, 1.0 equiv) in anhydrous dichloromethane $(5.0 \mathrm{~mL})$ was added 2,6-lutidine $(0.16 \mathrm{~mL}, 1.41$ mmol, 4.0 equiv) followed by the dropwise addition of triisopropylsilyl trifluoromethanesulfonate $(0.23 \mathrm{~mL}, 0.844 \mathrm{mmol}, 2.4$ equiv). This solution was stirred for $45 \mathrm{~min}$ then triethylamine $(0.75 \mathrm{~mL})$ and saturated aqueous sodium bicarbonate $(7$ $\mathrm{mL}$ ) were added and the mixture was stirred for five minutes. After a dilution with diethyl ether $(20 \mathrm{~mL})$, the layers were separated and the aqueous layer was extracted with diethyl ether $(3 \times 20 \mathrm{~mL})$. The combined organic layers were washed with water $(1 \times 15$ $\mathrm{mL})$ and brine $(1 \times 15 \mathrm{~mL})$, dried over anhydrous magnesium sulfate, and concentrated in vacuo. The crude oil was purified by flash chromatography (0-10\% diethyl ether/hexanes) to provide $0.22 \mathrm{~g}(>99 \%)$ of $\mathbf{2 3}$ as a clear, colorless oil: $[\alpha]^{23}{ }_{\mathrm{D}}+29.4(c=$ 1.84, chloroform); IR (neat) 2943, 2866, 1094, $1066 \mathrm{~cm}^{-1} ;{ }^{1} \mathrm{H}$ NMR $\left(500 \mathrm{MHz}, \mathrm{C}_{6} \mathrm{D}_{6}\right) \delta$ $5.72(\mathrm{dt}, J=14.5,7.1,1 \mathrm{H}), 5.54(\mathrm{ddd}, J=15.4,7.3,1.2,1 \mathrm{H}), 4.48-4.43(\mathrm{~m}, 1 \mathrm{H})$, 4.13-4.07 (m, 1H), 3.96-3.89 (m, 2H), 3.48 (dd, $J=12.5,7.3,1 \mathrm{H}), 2.35$ (ddd, $J=14.2$, $10.3,4.5,1 \mathrm{H}), 2.00-1.87$ (m, 4H), 1.64 (app. septet, $J=6.6,1 \mathrm{H}$ ), 1.57 (tt, $J=13.2,4.4$, 
1H), 1.52-1.41 (m, 2H), 1.38-1.27 (m, 3H), 1.25-1.19 (m, 21H), 1.19-1.15 (m, 21H), $0.92(\mathrm{~d}, J=6.6,3 \mathrm{H}), 0.92(\mathrm{~d}, J=6.6,3 \mathrm{H}), 0.84(\mathrm{~d}, J=6.8,3 \mathrm{H}) ;{ }^{13} \mathrm{C} \mathrm{NMR}(125 \mathrm{MHz}$, $\left.\mathrm{CDCl}_{3}\right) \delta 135.6,130.9,74.3,72.6,68.7,62.2,42.6,42.3,37.7,35.0,29.6,29.4,27.9$, 23.2, 23.0, 19.1, 19.0, 13.4, 13.0. HRMS (ESI), calcd for $\mathrm{C}_{34} \mathrm{H}_{70} \mathrm{O}_{3} \mathrm{Si}_{2} \mathrm{Na}[\mathrm{M}+\mathrm{Na}]^{+}$ 605.4761 , found 605.4775 .

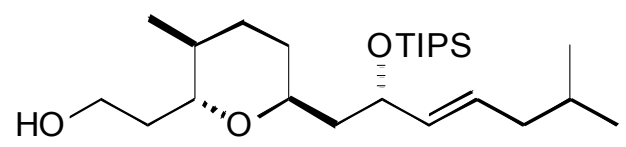

Alcohol from 23. Bis-protected diol $23(50.9 \mathrm{mg}, 0.858 \mathrm{mmol}, 1.0$ equiv) was dissolved in ethanol $(1.0 \mathrm{~mL})$ and cooled to $0{ }^{\circ} \mathrm{C}$. A solution of $p$-toluenesulfonic acid in ethanol ( $0.49 \mathrm{~mL}, 0.17 \mathrm{mmol}, 0.04 \mathrm{M}, 0.2$ equiv) was added and the mixture was allowed to warm slowly to $23{ }^{\circ} \mathrm{C}$. After stirring for $24 \mathrm{~h}$, the mixture was diluted with diethyl ether $(10 \mathrm{~mL})$ and saturated aqueous sodium bicarbonate $(3 \mathrm{~mL})$ was added. The resultant biphasic mixture was stirred at $23{ }^{\circ} \mathrm{C}$ for five minutes then the layers were separated and the aqueous layer was extracted with diethyl ether $(3 \times 20 \mathrm{~mL})$. The combined organic layers were washed with water $(1 \times 20 \mathrm{~mL})$ and brine $(1 \times 20 \mathrm{~mL})$, dried over anhydrous magnesium sulfate, and concentrated in vacuo. The crude oil was purified by flash chromatography (5-60\% diethyl ether/hexanes) to provide $21.5 \mathrm{mg}$ (59\%) of the desired alcohol and $12.0 \mathrm{mg}$ of the starting silyl ether $\mathbf{2 3}$ as clear, colorless oils. Resubjecting the starting material to the reaction conditions provided $5.3 \mathrm{mg}$ of the desired alcohol, corresponding to an overall yield after one recycling of $26.8 \mathrm{mg}(73 \%)$ : $[\alpha]^{23}+38.5\left(c=0.80\right.$, chloroform); IR (neat) 3452, 2948, 2866, 1084, $1061 \mathrm{~cm}^{-1} ;{ }^{1} \mathrm{H}$ NMR $\left(500 \mathrm{MHz}, \mathrm{CDCl}_{3}\right) \delta 5.60(\mathrm{dt}, J=14.9,7.1,1 \mathrm{H}), 5.39(\mathrm{dd}, J=15.4,7.7,1 \mathrm{H}), 4.27$ $(\mathrm{td}, J=8.6,4.6,1 \mathrm{H}), 3.98(\mathrm{dt}, J=9.3,4.2,1 \mathrm{H}), 3.81-3.72(\mathrm{~m}, 2 \mathrm{H}), 3.46(\mathrm{td}, J=9.3,2.7$, 
1H), 3.11 (br s, 1H), 2.28 (ddd, $J=14.4,10.0,4.6,1 \mathrm{H}), 1.94-1.78(\mathrm{~m}, 4 \mathrm{H}), 1.71-1.57$ (m, 3H), 1.50-1.30 (m, 4H), 1.09-1.04 (m, 21H), 0.91-0.84 (m, 9H); ${ }^{13} \mathrm{C}$ NMR (125 $\left.\mathrm{MHz}, \mathrm{CDCl}_{3}\right) \delta 134.2,130.9,71.7,69.5,62.1,41.6,39.5,35.5,35.1,29.2,28.5,27.5$, 22.7, 22.5, 18.4, 18.3, 12.6. HRMS (ESI), calcd for $\mathrm{C}_{25} \mathrm{H}_{50} \mathrm{O}_{3} \mathrm{SiNa}[\mathrm{M}+\mathrm{Na}]^{+}$449.3427, found 449.3428 .

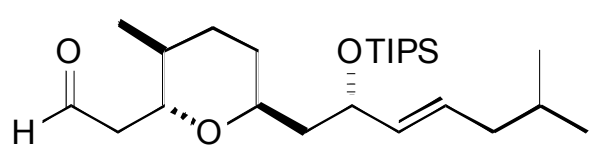

11

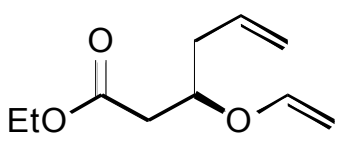

$12 \mathbf{a}$

3-Vinyloxyhex-5-enoic acid ethyl ester (12a). To a solution of $(R)$-ethyl 3hydroxyhex-5-enoate $(\mathbf{1 6 a})^{11}(0.222 \mathrm{~g}, 1.40 \mathrm{mmol}, 1.0$ equiv) in ethyl vinyl ether (7.4 $\mathrm{mL}$ ) was added mercuric trifluoroacetate $(60.0 \mathrm{mg}, 0.140 \mathrm{mmol}, 0.10$ equiv). This mixture was allowed to stir in a capped vessel for $24 \mathrm{~h}$. Following a dilution with diethyl ether $(10 \mathrm{~mL})$, the layers were separated. The organic layer was washed with saturated aqueous sodium bicarbonate $(10 \mathrm{~mL})$ and brine $(10 \mathrm{~mL})$, dried over anhydrous sodium sulfate, and concentrated in vacuo. The crude oil was immediately purified by flash chromatography on deactivated silica gel (1\% triethylamine in the desired eluant) $(0-40 \%$ diethyl ether/hexanes) to provide $48 \mathrm{mg}$ of the recovered starting material and $184 \mathrm{mg}$ (71\%) of 12a as a clear, colorless oil: $[\alpha]^{23}{ }_{D}-9.53$ ( $c=0.33$, chloroform); IR (neat) 2981, 2934, 1737, 1636, $1620 \mathrm{~cm}^{-1} ;{ }^{1} \mathrm{H}$ NMR $\left(500 \mathrm{MHz}, \mathrm{CDCl}_{3}\right) \delta 6.30(\mathrm{dd}, J=14.1,6.6,1 \mathrm{H})$, 
$5.78(\mathrm{ddt}, J=16.9,14.2,7.1,1 \mathrm{H}), 5.16-5.01(\mathrm{~m}, 2 \mathrm{H}), 4.33-4.26(\mathrm{~m}, 2 \mathrm{H}), 4.13(\mathrm{dq}, J=$ 7.1, 1.0, 2H), $4.01(\mathrm{dd}, J=6.6,1.7,1 \mathrm{H}), 2.59(\mathrm{dd}, J=15.9,7.6,1 \mathrm{H}), 2.49(\mathrm{dd}, J=15.7$, 5.4, 1H), 2.43-2.31 (m, 2H), $1.25(\mathrm{t}, J=7.1,3 \mathrm{H}) ;{ }^{13} \mathrm{C} \mathrm{NMR}\left(125 \mathrm{MHz}, \mathrm{CDCl}_{3}\right) \delta$ 173.0, 134.2, 118.4, 67.6, 60.9, 41.1, 40.8, 14.4. HRMS (ESI), calcd for $\mathrm{C}_{10} \mathrm{H}_{16} \mathrm{O}_{3} \mathrm{Na}[\mathrm{M}+\mathrm{Na}]^{+}$ 207.0997, found 207.0995. Anal. calcd for $\mathrm{C}_{10} \mathrm{H}_{10} \mathrm{O}_{3}$ : C, 65.19; H, 8.75. Found: C, 64.96; H, 9.00 .

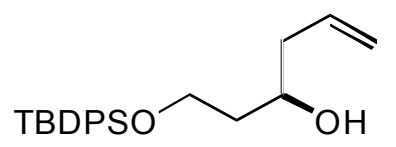

16b

(R)-3-Hydroxyhex-5-enyloxy-tert-butyldiphenylsilane (16b). ${ }^{12}$ To a solution of $(R)$ BINOL (0.82 g, $2.88 \mathrm{mmol}, 0.1$ equiv) and titanium tetraisopropoxide (0.85 mL, 2.88 mmol, 0.1 equiv) in anhydrous dichloromethane $(55 \mathrm{~mL})$ was added oven-dried, powdered $4 \AA$ molecular sieves $(11.3 \mathrm{~g})$. The resulting slurry was stirred for three hours then 3-(tert-butyldiphenylsilyloxy)propanal $(9.0 \mathrm{~g}, 28.8 \mathrm{mmol}, 1.0$ equiv) was added. Stirring continued for an additional ten minutes and then the solution was cooled to -78 ${ }^{\circ} \mathrm{C}$. Allyltributyltin $(9.8 \mathrm{~mL}, 31.7 \mathrm{mmol}, 1.1$ equiv) was added dropwise and the redorange solution was capped and placed in a $-20{ }^{\circ} \mathrm{C}$ freezer for three days. Saturated aqueous sodium bicarbonate $(50 \mathrm{~mL})$ was then added and the biphasic mixture was allowed to warm to $23{ }^{\circ} \mathrm{C}$ while stirring vigorously. After three hours, the layers were separated and the aqueous layer was extracted with dichloromethane $(3 \times 100 \mathrm{~mL})$. The combined organic layers were dried over anhydrous sodium sulfate, filtered through Celite, and concentrated in vacuo. The crude oil was purified by flash chromatography (5-40\% diethyl ether/hexanes) to yield $9.0 \mathrm{~g} \mathrm{(88 \% )}$ of the desired alcohol in 95\% ee as a 
clear, colorless oil: $[\alpha]^{23}{ }_{\mathrm{D}}+2.5(c=1.52$, dichloromethane); IR (neat) $3445,2931,1428$, $1111 \mathrm{~cm}^{-1} ;{ }^{1} \mathrm{H}$ NMR $\left(600 \mathrm{MHz}, \mathrm{CDCl}_{3}\right) \delta$ 7.71-7.70 (m, 4H), 7.47-7.41 (m, 6H), 5.87 (ddt, $J=17.2,14.5,7.1,1 \mathrm{H}), 5.12-5.08(\mathrm{~m}, 2 \mathrm{H}), 4.05-3.99(\mathrm{~m}, 1 \mathrm{H}), 3.94-3.85(\mathrm{~m}, 2 \mathrm{H})$, $3.23(\mathrm{~s}, 1 \mathrm{H}), 2.30(\mathrm{dtd}, J=20.5,13.5,7.0,2 \mathrm{H}), 1.79-1.72(\mathrm{~m}, 2 \mathrm{H}), 1.08(\mathrm{~s}, 9 \mathrm{H}) .{ }^{13} \mathrm{C}$ NMR (125 MHz, $\left.\mathrm{CDCl}_{3}\right) \delta 135.7,135.2,133.3,130.0,128.0,117.6,71.0,63.5,42.2$, 38.1, 27.0, 19.2. HRMS (ESI), calcd for $\mathrm{C}_{22} \mathrm{H}_{31} \mathrm{O}_{2} \mathrm{Si}[\mathrm{M}+\mathrm{H}]^{+}$355.2093, found 355.2093. Anal. calcd for $\mathrm{C}_{22} \mathrm{H}_{30} \mathrm{O}_{2} \mathrm{Si}: \mathrm{C}, 74.53 ; \mathrm{H}$, 8.53. Found: C, 74.70; H, 8.80.

\section{9:1 Titanium tetrabromide/titanium tetraisopropoxide mixed Lewis acid (a} representative procedure). To a solution of titanium tetrabromide in anhydrous dichloromethane $\left(1.55 \mathrm{~mL}, 527 \mathrm{mmol}, 0.34 \mathrm{M}, 1\right.$ equiv) at $0{ }^{\circ} \mathrm{C}$ was added neat titanium tetraisopropoxide ( $18 \mu \mathrm{L}, 0.061 \mathrm{mmol}, 0.12$ equiv). This solution was allowed to warm to $23^{\circ} \mathrm{C}$ and stir for $30 \mathrm{~min}$, and then was used directly.

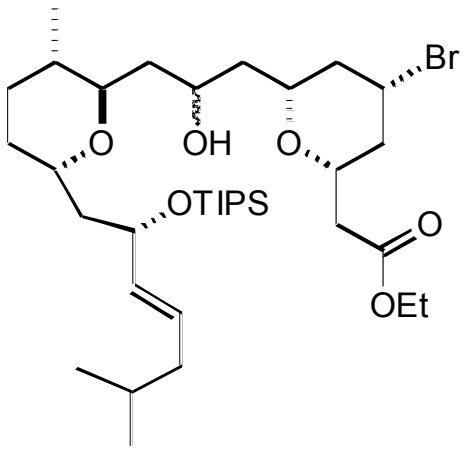

$10 \mathbf{a}$

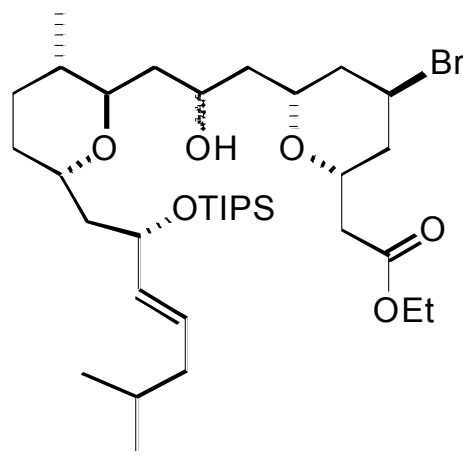

24a

MAP products 10a and 24a. Aldehyde 11 ( $20.0 \mathrm{mg}, 47.0 \mu \mathrm{mol}, 1.0$ equiv), enol ether 12a $(8.7 \mathrm{mg}, 47.0 \mu \mathrm{mol}, 1.0$ equiv), and 2,6-di-tert-butyl-4-methylpyridine (14.5 mg, 
$70.5 \mu \mathrm{mol}, 1.5$ equiv) were dissolved in anhydrous dichloromethane $(2.0 \mathrm{~mL})$. The solution was cooled to $-78{ }^{\circ} \mathrm{C}$ and a 9:1 titanium tetrabromide/titanium tetraisopropoxide Lewis acid blend, as a solution in dichloromethane $(0.50 \mathrm{~mL}, 0.19 \mu \mathrm{mol}, 0.34 \mathrm{M}, 4.0$ equiv), was added dropwise. After stirring for three hours at $-78^{\circ} \mathrm{C}$, a $1: 1$ mixture of triethylamine and methanol $(2 \mathrm{~mL})$ was added dropwise, followed by the addition of saturated aqueous sodium bicarbonate $(2 \mathrm{~mL})$. The biphasic mixture was allowed to warm to $23{ }^{\circ} \mathrm{C}$ and was then diluted with diethyl ether $(10 \mathrm{~mL})$. The layers were separated and the aqueous layer was extracted with diethyl ether $(3 \times 10 \mathrm{~mL})$. The combined organic layers were washed with water $(1 \times 10 \mathrm{~mL})$, and brine $(1 \times 10 \mathrm{~mL})$, dried over anhydrous sodium sulfate, and concentrated in vacuo. The crude oil was purified by flash chromatography (0-100\% diethyl ether/hexanes) to yield $10.1 \mathrm{mg}(31 \%)$ of $10 \mathbf{a}$ as a mixture of diastereomers at the $\mathrm{OH}$ center and $8.4 \mathrm{mg}(25 \%)$ of $\mathbf{2 4 a}$ as a mixture of diastereomers at the $\mathrm{OH}$ center: 10a: IR (thin film) 3521, 2946, 2866, 1738, $1087 \mathrm{~cm}^{-1} ;{ }^{1} \mathrm{H}$ NMR $\left(600 \mathrm{MHz}, \mathrm{CDCl}_{3}\right)$ $\delta 5.64-5.51(\mathrm{~m}, 1 \mathrm{H}), 5.45-5.35(\mathrm{~m}, 1 \mathrm{H}), 4.28(\mathrm{q}$, $J=6.8,1 \mathrm{H}), 4.23-4.10(\mathrm{~m}, 3 \mathrm{H}), 4.07-3.91(\mathrm{~m}, 2 \mathrm{H}), 3.86-3.74(\mathrm{~m}, 1 \mathrm{H}), 3.70-3.58(\mathrm{~m}$, $1 \mathrm{H}), 3.52-3.42(\mathrm{~m}, 1 \mathrm{H}), 2.65-2.52(\mathrm{~m}, 1 \mathrm{H}), 2.43(\mathrm{dd}, J=16.0,5.7,1 \mathrm{H}), 2.36-2.29(\mathrm{~m}$, $1 \mathrm{H}), 2.28-2.21(\mathrm{~m}, 1 \mathrm{H}), 2.20-2.10(\mathrm{~m}, 1 \mathrm{H}), 2.09-2.02(\mathrm{~m}, 1 \mathrm{H}), 1.99-1.85(\mathrm{~m}, 2 \mathrm{H})$, 1.84-1.65 (m, 6H), 1.64-1.24 (m, 9H), 1.14-1.03 (m, 21H), 095-0.80 (m, 9H); ${ }^{13} \mathrm{C}$ NMR $\left(150 \mathrm{MHz}, \mathrm{CDCl}_{3}\right) \delta 170.6,134.5,130.0,77.8,74.2,73.6,71.6,69.2,67.6,61.0,45.4$, $43.3,43.1,42.7,41.8,41.1,40.9,34.7,29.0,28.6,27.5,22.7,22.5,18.5,18.4,14.4,12.6$; HRMS (ESI), calcd for $\mathrm{C}_{35} \mathrm{H}_{65} \mathrm{BrO}_{6} \mathrm{SiNa}[\mathrm{M}+\mathrm{Na}]^{+}$711.3632, found 711.3629.

24a: IR (thin film) $3534,2951,2866,1738,1083 \mathrm{~cm}^{-1} ;{ }^{1} \mathrm{H} \mathrm{NMR}\left(500 \mathrm{MHz}, \mathrm{CDCl}_{3}\right) \delta$ $5.56(\mathrm{dt}, J=14.5,7.1,1 \mathrm{H}), 5.42(\mathrm{dd}, J=15.4,7.3,1 \mathrm{H}), 4.69(\mathrm{t}, J=2.9,1 \mathrm{H}), 4.37$ (dddd, 
$J=13.3,7.9,5.8,2.1,1 \mathrm{H}), 4.30(\mathrm{q}, J=5.4,1 \mathrm{H}), 4.16(\mathrm{q}, J=7.2,3 \mathrm{H}), 4.10-4.04(\mathrm{~m}$, 1H), 3.98-3.92 (m, 1H), 3.66-3.62 (m, 1H), 3.54-3.56 (m, 1H), $2.54(\mathrm{dd}, J=15.2,7.7$, $1 \mathrm{H}), 2.43(\mathrm{dd}, J=15.2,5.3,1 \mathrm{H}), 2.14(\mathrm{ddd}, J=13.5,8.2,5.3,1 \mathrm{H}), 2.05(\mathrm{dq}, J=14.5$, $1.9,1 \mathrm{H}), 2.00-1.87(\mathrm{~m}, 3 \mathrm{H}), 1.86-1.34(\mathrm{~m}, 10 \mathrm{H}), 1.31-1.24(\mathrm{~m}, 5 \mathrm{H}), 1.14-1.03(\mathrm{~m}$, 21H), 0.94-0.83 (m, 9H); ${ }^{13} \mathrm{C}$ NMR (150 MHz, $\left.\mathrm{CDCl}_{3}\right) \delta 170.8,134.6,130.1,73.5,73.2$, $71.7,69.4,69.0,68.3,61.0,49.2,43.1,41.8,40.8,40.5,39.7,39.0,34.8,28.9,28.6,27.4$, 22.7, 22.5, 18.5, 18.4, 14.4, 12.6; HRMS (ESI), calcd for $\mathrm{C}_{35} \mathrm{H}_{65} \mathrm{BrO}_{6} \mathrm{SiNa}[\mathrm{M}+\mathrm{Na}]^{+}$ 711.3632, found 711.3611

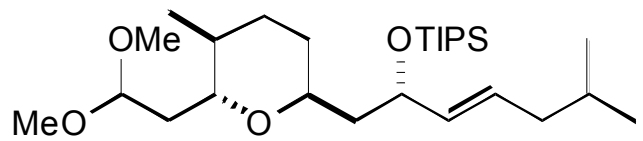

Acetal 27. To a solution of aldehyde $11(45.0 \mathrm{mg}, 0.106 \mathrm{mmol}, 1.0$ equiv) in a $1: 1$ mixture of dichloromethane and methanol $(2.5 \mathrm{~mL})$ was added camphorsulfonic acid (3.7 $\mathrm{mg}, 0.016 \mathrm{mmol}, 0.15$ equiv). After two hours, the mixture was diluted with diethyl ether $(5 \mathrm{~mL})$ and saturated aqueous sodium bicarbonate $(1 \mathrm{~mL})$. The resultant layers were separated and the aqueous layer was extracted with diethyl ether $(3 \times 10 \mathrm{~mL})$. The combined organic layers were washed with saturated aqueous sodium bicarbonate $(1 \times 10$ $\mathrm{mL})$ and brine $(1 \times 10 \mathrm{~mL})$, dried over anhydrous sodium sulfate, and concentrated in vacuo. The crude oil was purified by flash chromatography on deactivated silica gel (1\% triethylamine in the desired eluant) (0-20\% diethyl ether/hexanes) to provide $42 \mathrm{mg}$ (81\%) of 27 as a clear, colorless oil: $[\alpha]_{D}^{23}+40.8(c=1.12$, dichloromethane); IR (neat) 2941, 2867, 1124, $1060 \mathrm{~cm}^{-1} ;{ }^{1} \mathrm{H}$ NMR $\left(500 \mathrm{MHz}, \mathrm{CDCl}_{3}\right) \delta 5.57(\mathrm{dt}, J=14.6,7.1,1 \mathrm{H})$, 
$5.41(\mathrm{dd}, J=15.4,7.3,1 \mathrm{H}), 4.59(\mathrm{dd}, J=8.5,2.8,1 \mathrm{H}), 4.28($ app. q, $J=5.5,1 \mathrm{H}), 3.89$ (app. dq, $J=8.6,4.8,1 \mathrm{H}), 3.39-3.32(\mathrm{~m}, 1 \mathrm{H}), 3.32(\mathrm{~s}, 3 \mathrm{H}), 3.31(\mathrm{~s}, 3 \mathrm{H}), 2.11$ (ddd, $J=$ 13.7, 8.6, 5.4, 1H), 1.97-1.86 (m, 3H), 1.75-1.55 (m, 4H), 1.52-1.42 (m, 2H), 1.42-1.32 (m, 2H), 1.12-1.01 (m, 21H), 0.94-0.84 (m, 9H); $\left.{ }^{13} \mathrm{C} \mathrm{NMR} \mathrm{(125} \mathrm{MHz,} \mathrm{CDCl}_{3}\right) \delta$ 134.5, $130.0,102.2,72.6,71.5,68.7,53.4,52.5,41.8,41.0,36.5,34.8,28.7,28.6,27.2,22.7$, 22.5, 18.4, 18.3, 12.5. HRMS (ESI), calcd for $\mathrm{C}_{27} \mathrm{H}_{54} \mathrm{O}_{4} \mathrm{SiNa}[\mathrm{M}+\mathrm{Na}]^{+} 493.3689$, found 493.3689.

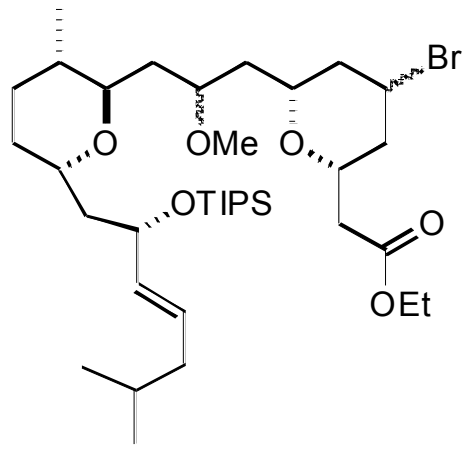

28a

Ester 28a. Acetal 27 (3.3 mg, 0.007 mmol, 1.0 equiv), enol ether 12a (1.5 mg, 0.008 mmol, 1.2 equiv), and 2,6-di-tert-butyl-4-methylpyridine (2.2 $\mathrm{mg}, 0.011 \mathrm{mmol}, 1.5$ equiv) were dissolved in anhydrous dichloromethane $(0.5 \mathrm{~mL})$. The solution was cooled to $-78{ }^{\circ} \mathrm{C}$ and titanium tetrabromide as a solution in dichloromethane $(82.0 \mu \mathrm{L}, 0.028$ mmol, $0.34 \mathrm{M}, 4.0$ equiv) was added dropwise. After two hours, a 1:1 mixture of methanol and triethylamine was added dropwise to the mixture, followed by the addition of saturated aqueous sodium bicarbonate $(2 \mathrm{~mL})$. The resultant biphasic mixture was allowed to warm to $23{ }^{\circ} \mathrm{C}$ and diluted with diethyl ether $(5 \mathrm{~mL})$. The layers were separated and the aqueous layer was extracted with diethyl ether $(3 \times 5 \mathrm{~mL})$. The 
combined organic layers were washed with saturated aqueous sodium bicarbonate $(1 \times 5$ $\mathrm{mL})$, water $(1 \times 5 \mathrm{~mL})$, and brine $(1 \times 5 \mathrm{~mL})$, dried over anhydrous sodium sulfate, and concentrated in vacuo. The crude oil was purified by flash chromatography (0-60\% diethyl ether/hexanes) to provide $0.5 \mathrm{mg}$ of the starting acetal 27 and $3.4 \mathrm{mg}(69 \%)$ of 28a as a light yellow oil consisting of four diastereomers (3.9:1 equatorial:axial bromide; 1:1 at the alcohol center): IR (thin film) 2944, 2927, 2866, 1740, $1091 \mathrm{~cm}^{-1} ;{ }^{1} \mathrm{H}$ NMR (500 MHz, $\left.\mathrm{CDCl}_{3}\right) \delta 5.61-5.51(\mathrm{~m}, 1 \mathrm{H}), 5.42(\mathrm{dd}, J=15.3,7.1,1 \mathrm{H}), 4.73-4.68(\mathrm{~m}$, $0.25 \mathrm{H}), 4.39-4.23(\mathrm{~m}, 1 \mathrm{H}), 4.22-4.10(\mathrm{~m}, 2.75 \mathrm{H}), 3.93-3.84(\mathrm{~m}, 1 \mathrm{H}), 3.83-3.75(\mathrm{~m}$, $1 \mathrm{H}), 3.71-3.65(\mathrm{~m}, 0.25 \mathrm{H}), 3.61-3.46(\mathrm{~m}, 2 \mathrm{H}), 3.45-3.38(\mathrm{~m}, 0.75 \mathrm{H}), 3.37-3.27(\mathrm{~m}$, $3 \mathrm{H}), 2.57(\mathrm{dt}, J=15.0,7.3,1 \mathrm{H}), 2.40(\mathrm{ddd}, J=15.3,5.8,2.4,1 \mathrm{H}), 2.35-2.25(\mathrm{~m}, 1.5 \mathrm{H})$, $2.23-2.13(\mathrm{~m}, 0.5 \mathrm{H}), 2.10-1.85(\mathrm{~m}, 4 \mathrm{H}), 1.83-1.47(\mathrm{~m}, 16 \mathrm{H}), 1.40-1.19(\mathrm{~m}, 10 \mathrm{H})$, 1.15-1.00 (m, 21H), 0.98-0.78 (m, 9H); HRMS (ESI), calcd for $\mathrm{C}_{36} \mathrm{H}_{67} \mathrm{BrO}_{6} \mathrm{SiNa}[\mathrm{M}+$ $\mathrm{Na}]^{+} 725.3788$, found 725.3796 .

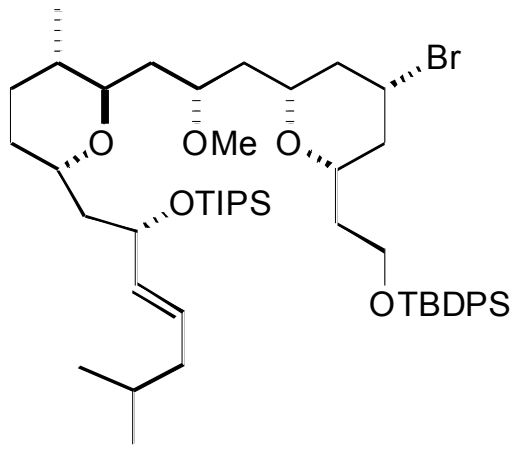

$28 b$

Methyl ether 28b. A solution of $\mathbf{1 0 b}(818 \mathrm{mg}, 0.923 \mathrm{mmol}, 1.0$ equiv) in anhydrous dichloromethane $(18.0 \mathrm{~mL})$ was treated with 2,6-di-tert-butyl-4-methylpyridine $(4.17 \mathrm{~g}$, 
$20.3 \mathrm{mmol}, 22$ equiv) then methyl trifluoromethanesulfonate $(1.57 \mathrm{~mL}, 13.9 \mathrm{mmol}, 15$ equiv). After $20 \mathrm{~h}$, triethylamine ( $6 \mathrm{~mL}$ ) was added dropwise to the mixture, followed by the addition of saturated aqueous sodium bicarbonate $(6 \mathrm{~mL})$. The mixture was then diluted with diethyl ether $(25 \mathrm{~mL})$ and the layers were separated. The aqueous layer was extracted with diethyl ether $(3 \times 25 \mathrm{~mL})$. The combined organic layers were washed with saturated aqueous sodium bicarbonate $(1 \times 25 \mathrm{~mL})$ and brine $(1 \times 25 \mathrm{~mL})$, dried over anhydrous sodium sulfate, and concentrated in vacuo. The crude oil was purified by flash chromatography (0-40\% diethyl ether/hexanes) to provide $115 \mathrm{mg}$ of the starting alcohol 10b and $740 \mathrm{mg}(89 \%)$ of methyl ether $\mathbf{2 8 b}$ as a clear, colorless oil: $[\alpha]^{23}{ }_{\mathrm{D}}+18.2(c=$ 0.88, dichloromethane); IR (thin film) 2955, 2928, 2865, 1106, $1095 \mathrm{~cm}^{-1} ;{ }^{1} \mathrm{H}$ NMR (600 $\left.\mathrm{MHz}, \mathrm{CDCl}_{3}\right) \delta 7.66(\mathrm{~d}, J=6.6,4 \mathrm{H}), 7.47-7.36(\mathrm{~m}, 6 \mathrm{H}), 5.56(\mathrm{dt}, J=14.9,7.0,1 \mathrm{H})$, $5.43(\mathrm{dd}, J=15.5,7.3,1 \mathrm{H}), 4.29($ app. q, $J=6.5,1 \mathrm{H}), 4.20-4.10(\mathrm{~m}, 1 \mathrm{H}), 3.93-3.84(\mathrm{~m}$, $1 \mathrm{H}), 3.84-3.76(\mathrm{~m}, 1 \mathrm{H}), 3.74(\mathrm{dt}, J=10.6,5.9,1 \mathrm{H}), 3.60-3.49(\mathrm{~m}, 2 \mathrm{H}), 3.46(\mathrm{dt}, J=$ $10.7,6.1,1 \mathrm{H}), 3.40(\mathrm{t}, J=7.6,1 \mathrm{H}), 3.29(\mathrm{~s}, 3 \mathrm{H}), 2.35-2.25(\mathrm{~m}, 1 \mathrm{H}), 2.24-2.15(\mathrm{~m}, 1 \mathrm{H})$, $2.07-1.98(\mathrm{~m}, 1 \mathrm{H}), 1.97-1.85(\mathrm{~m}, 2 \mathrm{H}), 1.84-1.55(\mathrm{~m}, 10 \mathrm{H}), 1.55-1.45(\mathrm{~m}, 2 \mathrm{H})$, $1.42-1.25(\mathrm{~m}, 3 \mathrm{H}), 1.15-1.02(\mathrm{~m}, 30 \mathrm{H}), 0.95-0.86(\mathrm{~m}, 9 \mathrm{H}) ;{ }^{13} \mathrm{C}$ NMR $(125 \mathrm{MHz}$, $\left.\mathrm{CDCl}_{3}\right) \delta 135.7,134.7,134.1,134.0,129.9,129.8,127.9,116.4,74.6,74.5,74.4,72.9$, 71.7, 68.5, 60.4, 56.2, 47.2, 43.8, 43.6, 41.8, 41.6, 40.2, 39.0, 38.6, 34.7, 30.4, 28.6, 28.5, 27.1, 22.7, 22.5, 19.4, 18.6, 18.4, 12.6; HRMS (ESI), calcd for $\mathrm{C}_{50} \mathrm{H}_{83} \mathrm{BrO}_{5} \mathrm{Si}_{2} \mathrm{Na}[\mathrm{M}+$ $\mathrm{Na}]^{+}$921.4860, found 921.4861 . 


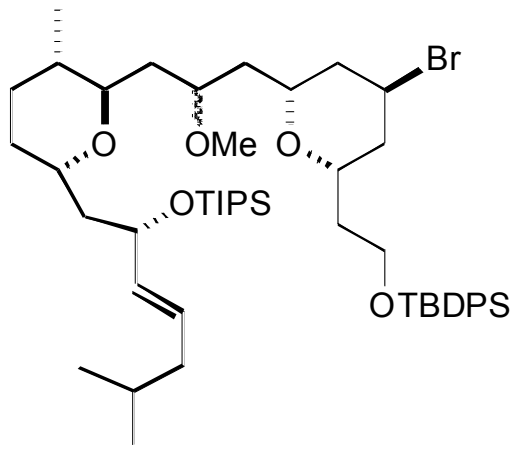

55

Methyl ether 55. A solution of $\mathbf{2 4 b}(672 \mathrm{mg}, 0.758 \mathrm{mmol}, 1.0$ equiv) in anhydrous dichloromethane $(30.0 \mathrm{~mL})$ was treated with proton sponge $(1.0 \mathrm{~g}, 4.63 \mathrm{mmol}, 6.1$ equiv), oven-dried $4 \AA$ molecular sieves $(1.3 \mathrm{~g})$, then trimethyloxonium tetrafluoroborate (561 $\mathrm{mg}, 3.79 \mathrm{mmol}, 5.0$ equiv). After $20 \mathrm{~h}$, the mixture was filtered through Celite, and the filtrate was concentrated in vacuo. The crude oil was purified by flash chromatography (0-40\% diethyl ether/hexanes) to provide 696 (100\%) of methyl ether $\mathbf{5 5}$ as a clear, colorless oil: $[\alpha]^{23}+21.8(c=1.75$, dichloromethane); IR (thin film) 2928, 2865, 1111, $1092 \mathrm{~cm}^{-1} ;{ }^{1} \mathrm{H}$ NMR $\left(600 \mathrm{MHz}, \mathrm{CDCl}_{3}\right) \delta 7.68(\mathrm{dd}, J=6.5,1.3,4 \mathrm{H}), 7.47-7.36(\mathrm{~m}, 6 \mathrm{H})$, $5.56(\mathrm{dt}, J=15.0,7.1,1 \mathrm{H}), 5.43(\mathrm{dd}, J=15.4,7.2,1 \mathrm{H}), 4.73(\mathrm{t}, J=2.6,1 \mathrm{H}), 4.29$ (app. $\mathrm{q}, J=6.7,1 \mathrm{H}), 4.18-4.10(\mathrm{~m}, 1 \mathrm{H}), 4.05(\mathrm{dt}, J=11.1,6.2,1 \mathrm{H}), 3.92-3.85(\mathrm{~m}, 1 \mathrm{H})$, $3.84-3.73(\mathrm{~m}, 2 \mathrm{H}), 3.58-3.50(\mathrm{~m}, 1 \mathrm{H}), 3.43(\mathrm{dt}, J=7.5,2.6,1 \mathrm{H}), 3.32(\mathrm{~s}, 3 \mathrm{H}), 2.09(\mathrm{~d}, J$ $=14.2,1 \mathrm{H}), 2.05-1.97(\mathrm{~m}, 2 \mathrm{H}), 1.97-1.85(\mathrm{~m}, 2 \mathrm{H}), 1.85-1.43(\mathrm{~m}, 13 \mathrm{H}), 1.40-1.20(\mathrm{~m}$, $2 \mathrm{H}), 1.15-1.03(\mathrm{~m}, 30 \mathrm{H}), 0.97-0.86(\mathrm{~m}, 9 \mathrm{H}) ;{ }^{13} \mathrm{C} \mathrm{NMR}\left(150 \mathrm{MHz}, \mathrm{CDCl}_{3}\right) \delta$ 135.7, $134.7,134.1,134.0,129.8,129.7,127.8,127.8,74.4,72.8,71.6,69.5,69.4,68.4,60.6$, $56.8,50.9,41.8,41.7,40.4,40.0,39.8,38.9,38.8,34.6,28.6,28.5,27.0,22.7,22.5,19.4$, 
18.6, 18.5, 18.3, 12.6; HRMS (ESI), calcd for $\mathrm{C}_{50} \mathrm{H}_{83} \mathrm{BrO}_{5} \mathrm{Si}_{2} \mathrm{Na}[\mathrm{M}+\mathrm{Na}]^{+}$921.4860, found 921.4839 .

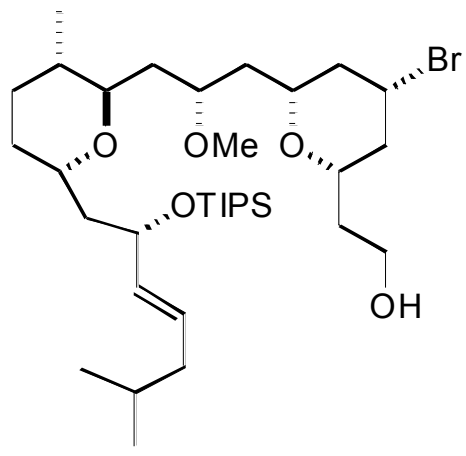

Alcohol 29. To a solution of silyl ether $\mathbf{2 8 b}(37.4 \mathrm{mg}, 0.042 \mathrm{mmol}, 1.0$ equiv) in DMPU $(2.8 \mathrm{~mL})$ were added $8 \mathrm{M}$ potassium hydroxide $(0.36 \mathrm{~mL})$ and acetonitrile $(2.8$ $\mathrm{mL})$. After $14 \mathrm{~h}$, the mixture was diluted with diethyl ether $(50 \mathrm{~mL})$ and the layers were separated. The aqueous layer was extracted with diethyl ether $(3 \times 25 \mathrm{~mL})$. The combined organic layers were washed with water $(3 \times 30 \mathrm{~mL})$ and brine $(1 \times 25)$, dried over anhydrous sodium sulfate, and concentrated in vacuo. The crude oil was purified by flash chromatography (10-100\% diethyl ether/hexanes) to provide $8.3 \mathrm{mg}$ of the starting silyl ether $\mathbf{2 8 b}$ and $20.0 \mathrm{mg}(73 \%)$ of alcohol 29 as a clear, colorless oil: $[\alpha]^{23}+18.6(c$ $=0.93$, dichloromethane); IR (thin film) 3453, 2952, 2867, $1088 \mathrm{~cm}^{-1} ;{ }^{1} \mathrm{H}$ NMR (600 $\left.\mathrm{MHz}, \mathrm{CDCl}_{3}\right) \delta 5.57(\mathrm{dt}, J=14.8,6.8,1 \mathrm{H}), 5.44(\mathrm{dd}, J=15.3,7.0,1 \mathrm{H}), 4.27$ (app. q, $J=$ 6.4, 1H), 4.20-4.13 (m, 1H), 4.01-3.94 (m, 1H), 3.87-3.77 (m, 1H), 3.68-3.60 (m, 2H), $3.57(\mathrm{t}, J=10.5,1 \mathrm{H}), 3.45-3.39(\mathrm{~m}, 2 \mathrm{H}), 3.33(\mathrm{~s}, 3 \mathrm{H}), 3.18-3.08(\mathrm{~m}, 1 \mathrm{H}), 2.30-2.18(\mathrm{~m}$, $3 \mathrm{H}), 2.02(\mathrm{dt}, J=13.1,6.1,1 \mathrm{H}), 1.98-1.86(\mathrm{~m}, 3 \mathrm{H}), 1.84-1.25(\mathrm{~m}, 13 \mathrm{H}), 1.25-0.86(\mathrm{~m}$, 
21H), 0.93-0.86 (m, 9H); $\left.{ }^{13} \mathrm{C} \mathrm{NMR} \mathrm{(150} \mathrm{MHz,} \mathrm{CDCl}_{3}\right) \delta$ 134.5, 129.9, 75.6, 75.1, 74.4, $72.8,72.5,71.6,69.1,58.9,56.3,46.4,43.7,43.5,41.7,40.7,39.0,38.0,37.5,35.4,28.6$, 27.2, 22.6, 22.5, 18.4, 18.3, 12.5; HRMS (ESI), calcd for $\mathrm{C}_{34} \mathrm{H}_{65} \mathrm{BrO}_{5} \mathrm{SiNa}[\mathrm{M}+\mathrm{Na}]^{+}$ 683.3682, found 683.3672 .

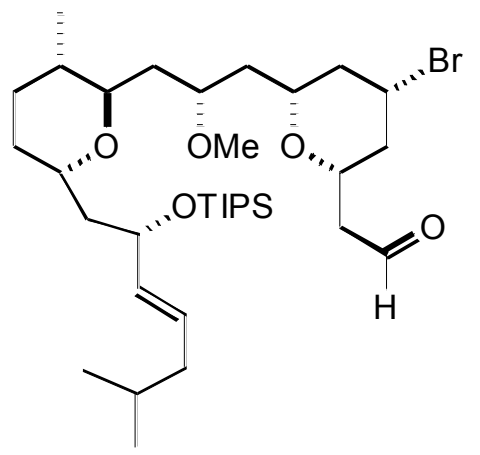

Aldehyde from 29. A solution of alcohol $29(10.0 \mathrm{mg}, 0.05 \mathrm{mmol}, 1.0$ equiv) in anhydrous dichloromethane $(0.5 \mathrm{~mL})$ was treated with pyridine $(5.4 \mu \mathrm{L}, 0.067 \mathrm{mmol}, 4.4$ equiv) then Dess-Martin periodinane (12.7 $\mathrm{mg} 0.030 \mathrm{mmol}, 2.0$ equiv). After stirring for 45 min, A 1:1 solution of saturated aqueous sodium bicarbonate and saturated aqueous sodium bisulfate $(1 \mathrm{~mL})$ was added. This mixture was stirred vigorously for five minutes, and then diluted with diethyl ether $(3 \mathrm{~mL})$. The layers were separated and the aqueous layer was extracted with diethyl ether $(3 \times 5 \mathrm{~mL})$. The combined organic layers were washed with saturated aqueous sodium bicarbonate $(1 \times 5 \mathrm{~mL})$ and brine $(1 \times 5 \mathrm{~mL})$ then dried over anhydrous sodium sulfate and concentrated in vacuo. The crude oil was purified by flash chromatography on deactivated silica gel (1\% triethylamine in the desired solvent) (0-40\% diethyl ether/hexanes) to provide $7.3 \mathrm{mg}(73 \%)$ of the desired aldehyde as a light yellow oil: $[\alpha]^{23}+23.7(c=0.34$, dichloromethane); IR (thin film) 
2944, 2866, 1729, $1091 \mathrm{~cm}^{-1} ;{ }^{1} \mathrm{H}$ NMR $\left(600 \mathrm{MHz}, \mathrm{CDCl}_{3}\right) \delta 9.76(\mathrm{t}, J=2.1,1 \mathrm{H}), 5.56$ (dt, $J=15.0,7.1,1 \mathrm{H}), 5.43(\mathrm{dd}, J=15.4,7.2,1 \mathrm{H}), 4.28$ (app. q, $J=7.0,1 \mathrm{H}), 4.15$ (tt, $J=$ $11.9,4.5,1 \mathrm{H}), 3.93-3.84(\mathrm{~m}, 2 \mathrm{H}), 3.58-3.49(\mathrm{~m}, 2 \mathrm{H}), 3.40(\mathrm{t}, J=7.5,1 \mathrm{H}), 3.29(\mathrm{~s}, 3 \mathrm{H})$, $2.63(\mathrm{ddd}, J=16.5,8.0,2.4,1 \mathrm{H}), 2.47(\mathrm{ddd}, J=16.5,4.6,1.6,1 \mathrm{H}), 2.32-2.25(\mathrm{~m}, 2 \mathrm{H})$, $2.05-1.85(\mathrm{~m}, 4 \mathrm{H}), 1.82-1.24(\mathrm{~m}, 12 \mathrm{H}), 1.15-1.00(\mathrm{~m}, 21 \mathrm{H}), 0.94-0.86(\mathrm{~m}, 9 \mathrm{H}) ;{ }^{13} \mathrm{C}$ NMR (150 MHz, $\left.\mathrm{CDCl}_{3}\right) \delta$ 200.34, 134.7, 129.9, 74.9, 74.5, 72.9, 72.7, 71.7, 68.6, 56.3, 49.3, 45.6, 43.4, 43.0, 41.9, 41.6, 39.9, 38.7, 34.9, 30.6, 28.6, 27.1, 22.7, 22.5, 18.6, 18.4, 12.7; HRMS (ESI), calcd for $\mathrm{C}_{34} \mathrm{H}_{63} \mathrm{BrO}_{5} \mathrm{SiNa}[\mathrm{M}+\mathrm{Na}]^{+}$681.3526, found 681.3514.

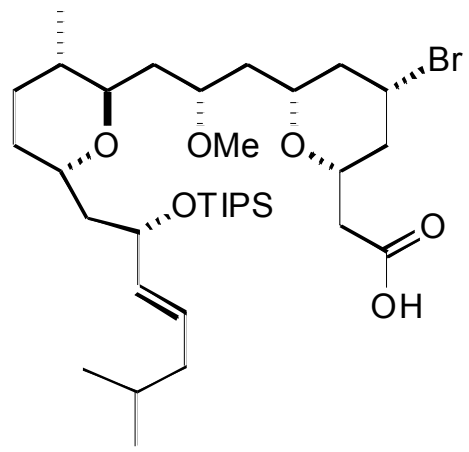

Carboxylic acid from 29. (by Lindgren oxidation): To a solution of the aldehyde described above (6.8 $\mathrm{mg}, 0.010 \mathrm{mmol}, 1.0$ equiv) in tert-butanol $(1 \mathrm{~mL})$ was added 2methyl-2-butene ( $22 \mu \mathrm{L}, 0.206 \mathrm{mmol}, 20$ equiv). A solution of sodium chlorite (14.0 mg, $0.155 \mathrm{mmol}, 15$ equiv) and monobasic sodium phosphate $(21.0 \mathrm{mg}, 0.155 \mathrm{mmol}, 15$ equiv) in water $(0.5 \mathrm{~mL})$ was prepared and added to the reaction mixture. After stirring for two hours, the mixture was diluted with diethyl ether $(5 \mathrm{~mL})$ and the layers were separated. The aqueous layer was extracted with diethyl ether $(3 \times 10 \mathrm{~mL})$. The combined organic layers were washed with brine $(1 \times 10 \mathrm{~mL})$ then dried over anhydrous 
sodium sulfate and concentrated in vacuo. The crude oil was purified by flash chromatography (0-100\% diethyl ether/hexanes with $0.1 \%$ acetic acid) to provide $6.2 \mathrm{mg}$ (89\%) of the desired carboxylic acid as a light yellow oil.

(by Jones oxidation): Alcohol 29 (407 mg, $0.615 \mathrm{mmol}, 1$ equiv) was dissolved in acetone $(14.0 \mathrm{~mL})$ and cooled to $-20{ }^{\circ} \mathrm{C}$. Jones reagent ${ }^{13}(433 \mu \mathrm{L})$ was then added dropwise and the mixture was allowed to warm to $0{ }^{\circ} \mathrm{C}$. After stirring for $90 \mathrm{~min}$, isopropanol $(7 \mathrm{~mL})$ was added and the mixture was diluted with diethyl ether $(25 \mathrm{~mL})$. Following separation of the resultant layers, the aqueous layer was extracted with diethyl ether $(3 \times 25 \mathrm{~mL})$. The combined organic layers were washed with water $(1 \times 25 \mathrm{~mL})$ and brine $(1 \times 25 \mathrm{~mL})$ then dried over anhydrous sodium sulfate and concentrated in vacuo. The crude oil was purified by flash chromatography (10-100\% diethyl ether/hexanes with $0.1 \%$ acetic acid) to provide $357 \mathrm{mg}(86 \%)$ of the desired carboxylic acid as a light yellow oil: $[\alpha]^{23}+23.2(c=2.33$, chloroform); IR (thin film) 2927,2866 , $1716,1088 \mathrm{~cm}^{-1} ;{ }^{1} \mathrm{H}$ NMR $\left(600 \mathrm{MHz}, \mathrm{CDCl}_{3}\right) \delta 5.56(\mathrm{dt}, J=15.0,7.0,1 \mathrm{H}), 5.43(\mathrm{dd}, J=$ $15.4,7.2,1 \mathrm{H}$ ), 4.27 (app. q, $J=6.8,1 \mathrm{H}$ ), 4.15 (tt, $J=11.8,4.4,1 \mathrm{H}$ ), 3.94 (app. quintet, $J$ $=4.6,1 \mathrm{H}), 3.75(\mathrm{dq}, J=11.4,5.9,1 \mathrm{H}), 3.58-3.47(\mathrm{~m}, 2 \mathrm{H}), 3.42(\mathrm{t}, J=7.5,1 \mathrm{H}), 3.30(\mathrm{~s}$, $3 \mathrm{H}), 2.57(\mathrm{dd}, J=15.5,7.1,1 \mathrm{H}), 2.47(\mathrm{dd}, J=16.5,5.2,1 \mathrm{H}), 2.37-2.30(\mathrm{~m}, 1 \mathrm{H})$, 2.29-2.23 (m, 1H), $2.01(\mathrm{dt}, J=13.3,6.4,1 \mathrm{H}), 1.97-1.87(\mathrm{~m}, 2 \mathrm{H}), 1.83(\mathrm{dt}, J=14.0,6.3$, $1 \mathrm{H}), 1.79-1.66(\mathrm{~m}, 4 \mathrm{H}), 1.66-1.56(\mathrm{~m}, 4 \mathrm{H}), 1.55-1.45(\mathrm{~m}, 2 \mathrm{H}), 1.40-1.31(\mathrm{~m}, 2 \mathrm{H})$, 1.13-1.01 (m, 21H), 0.95-0.87 (m, 9H); ${ }^{13} \mathrm{C}$ NMR (150 MHz, $\left.\mathrm{CDCl}_{3}\right) \delta 174.2,134.6$, $130.0,75.1,74.9,73.9,73.3,71.8,68.8,56.4,45.5,43.4,42.7,41.8,41.3,40.8,39.8$, 38.1, 34.8, 30.5, 28.6, 27.1, 22.7, 22.5, 18.6, 18.4, 18.3, 12.6; HRMS (ESI), calcd for $\mathrm{C}_{34} \mathrm{H}_{63} \mathrm{BrO}_{6} \mathrm{SiNa}[\mathrm{M}+\mathrm{Na}]^{+}$697.3475, found 697.3484. 


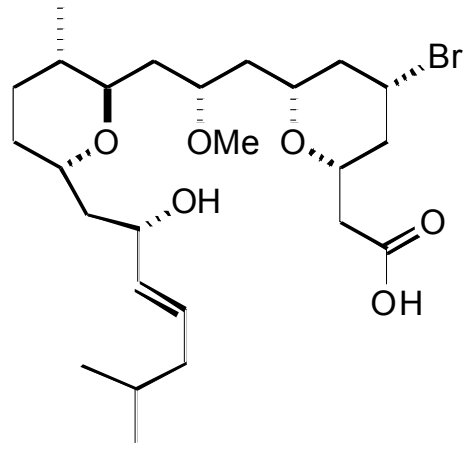

Seco acid 30. The carboxylic acid described above (39.7 mg, $0.056 \mathrm{mmol}, 1.0$ equiv) was dissolved in THF $(8.0 \mathrm{~mL})$ and cooled to $0{ }^{\circ} \mathrm{C}$. A solution of tetrabutylammonium fluoride in THF (281 $\mu \mathrm{L}, 1.0 \mathrm{M}, 0.281 \mathrm{mmol}, 5.0$ equiv) was then added dropwise and the mixture was allowed to warm to $23{ }^{\circ} \mathrm{C}$. After stirring for four hours, the mixture was diluted with water $(10 \mathrm{~mL})$. The resultant layers were separated and the aqueous layer was extracted with diethyl ether $(3 \times 20 \mathrm{~mL})$. The combined organic layers were washed with brine $(1 \times 20 \mathrm{~mL})$ then dried over anhydrous sodium sulfate and concentrated in vacuo. The crude oil was purified by flash chromatography (20-100\% diethyl ether/hexanes with $0.1 \%$ acetic acid) to provide $31.0 \mathrm{mg}(100 \%)$ of seco acid $\mathbf{3 0}$ as a viscous light yellow oil: $[\alpha]^{23}+21.4$ ( $c=1.50$, chloroform); IR (thin film) 3441,2957 , 2925, 2854, 1729, $1463 \mathrm{~cm}^{-1} ;{ }^{1} \mathrm{H}$ NMR $\left(600 \mathrm{MHz}, \mathrm{CDCl}_{3}\right) \delta 5.64(\mathrm{dt}, J=14.9,7.1,1 \mathrm{H})$, $5.44(\mathrm{dd}, J=15.3,6.6,1 \mathrm{H}), 4.30(\mathrm{~m}, 1 \mathrm{H}), 4.20-4.10(\mathrm{~m}, 1 \mathrm{H}), 4.04-3.92(\mathrm{~m}, 1 \mathrm{H})$, 3.83-3.73 (m, 1H), 3.69-3.60 (m, 1H), 3.53-3.40 (m, 2H), $3.31(\mathrm{~s}, 3 \mathrm{H}), 2.57-2.41(\mathrm{~m}$, 2H), 2.34-2.17 (m, 2H), 1.98-1.89 (m, 4H), 1.81-1.67 (m, 4H), 1.66-1.60 (m, 3H), $1.56-1.42(\mathrm{~m}, 4 \mathrm{H}), 1.40-1.31(\mathrm{~m}, 1 \mathrm{H}), 0.98(\mathrm{~d}, J=6.8,3 \mathrm{H}), 0.90-0.85(\mathrm{~m}, 6 \mathrm{H}) ;{ }^{13} \mathrm{C}$ NMR (150 MHz, $\left.\mathrm{CDCl}_{3}\right) \delta 174.2,133.4,130.5,74.6,74.5,74.2,73.8,72.5,70.9,56.5$, 


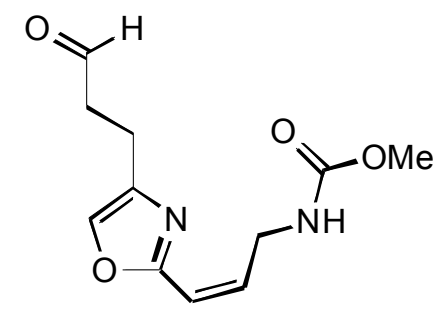

Side chain aldehyde 33. Prepared as previously reported. ${ }^{14}$ The following data is consistent with that which is reported: ${ }^{1} \mathrm{H}$ NMR $\left(600 \mathrm{MHz}, \mathrm{CDCl}_{3}\right) \delta 9.86(\mathrm{t}, J=1.1$, 1H), $7.39(\mathrm{~s}, 1 \mathrm{H}), 6.29(\mathrm{~d}, J=11.7,1 \mathrm{H}), 6.16-6.07(\mathrm{~m}, 1 \mathrm{H}), 5.49(\mathrm{br} \mathrm{s}, 1 \mathrm{H}), 4.32(\mathrm{~s}, 2 \mathrm{H})$, $3.70(\mathrm{~s}, 3 \mathrm{H}), 2.96-2.80(\mathrm{~m}, 4 \mathrm{H})$.

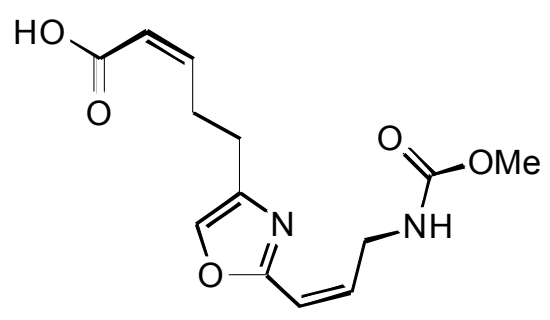

Side chain carboxylic acid 34. Prepared as previously reported from aldehyde 33. ${ }^{15,16}$ ${ }^{1} \mathrm{H}$ NMR $\left(600 \mathrm{MHz}, \mathrm{CDCl}_{3}\right) \delta 7.38(\mathrm{~s}, 1 \mathrm{H}), 6.30(\mathrm{~d}, J=11.6,2 \mathrm{H}), 6.08(\mathrm{dt}, J=12.5,6.5$, $1 \mathrm{H}), 5.83(\mathrm{~d}, J=11.5,1 \mathrm{H}), 5.59(\mathrm{br} \mathrm{s}, 1 \mathrm{H}), 4.32(\mathrm{~s}, 2 \mathrm{H}), 3.68(\mathrm{~s}, 3 \mathrm{H}), 3.02(\mathrm{~d}, J=6.7$, 2H), $2.72(\mathrm{t}, J=7.2,2 \mathrm{H}) .{ }^{13} \mathrm{C}$ NMR $\left(125 \mathrm{MHz}, \mathrm{CDCl}_{3}\right) \delta 170.7,160.3,150.2,141.0$, 
136.7, 134.3, 120.8, 116.7, 52.4, 39.7, 27.8, 25.5. LRMS (ESI), calcd for $\mathrm{C}_{13} \mathrm{H}_{16} \mathrm{~N}_{2} \mathrm{O}_{5} \mathrm{Na}$ $[\mathrm{M}+\mathrm{Na}]^{+}$303.1, found 303.4.

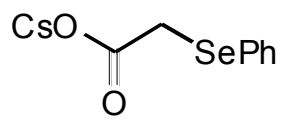

41

Cesium 2-(phenylselenyl)acetate (41). ${ }^{17}$ Cesium carbonate $(60.6 \mathrm{mg}, 0.186 \mathrm{mmol}, 0.4$ equiv), as a solution in $1.4 \mathrm{~mL}$ water, was added to a solution of 2-(phenylselenyl)acetic acid (100 mg, $0.465 \mathrm{mmol}, 1.0$ equiv) in diethyl ether $(38 \mathrm{~mL})$. This mixture was stirred for $45 \mathrm{~min}$ then was allowed to set for $19 \mathrm{~h}$. Subsequent concentration in vacuo provided a light yellow solid which was washed with dichloromethane $(50 \mathrm{~mL})$ and dried under vacuum (0.1 Torr) to provide $160 \mathrm{mg}(100 \%)$ of the cesium carboxylate, as a white solid: IR (thin film) 3379, 3286, 1660, $1558 \mathrm{~cm}^{-1} ;{ }^{1} \mathrm{H}$ NMR (600 MHz, $\left.\mathrm{D}_{2} \mathrm{O}\right) \delta 7.57(\mathrm{~d}, J=6.5$, 2H), 7.43-7.24 (m, 3H), $3.52(\mathrm{~s}, 2 \mathrm{H}) .{ }^{13} \mathrm{C}$ NMR (150 MHz, $\left.\mathrm{D}_{2} \mathrm{O}\right) \delta$ 178.5, 132.2, 129.9, 129.5, 127.4, 31.4. HRMS (ESI), calcd for $\mathrm{C}_{8} \mathrm{H}_{7} \mathrm{O}_{2} \mathrm{SeCsNa}[\mathrm{M}+\mathrm{Na}]^{+}$370.8564, found 370.8558 .

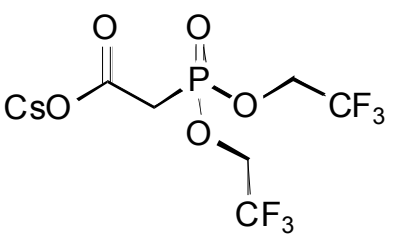




\section{Cesium 2-((bis(2,2,2-trifluoroethoxy)phosphoryl) acetate (42). ${ }^{17} \quad \operatorname{Bis}(2,2,2-$} trifluoroethyl) phosphonoacetic acid (30.0 mg, $0.098 \mathrm{mmol}, 1.0$ equiv) was dissolved in diethyl ether $(8.0 \mathrm{~mL})$ and cesium carbonate $(15.4 \mathrm{mg}, 0.047 \mathrm{mmol}, 0.5$ equiv), as a solution in $0.3 \mathrm{~mL}$ water, was added. This mixture was stirred for one hour then was allowed to set for $19 \mathrm{~h}$. Subsequent concentration in vacuo provided $43.1 \mathrm{mg}(100 \%)$ of the cesium carboxylate, which was used without further purification: IR (thin film) 3378, 2972, 1601, 1368, 1292, 1242, $1171 \mathrm{~cm}^{-1} ;{ }^{1} \mathrm{H}$ NMR (500 MHz, $\left.\mathrm{D}_{2} \mathrm{O}\right) \delta 4.60$ (app. quintet, $J=8.3,4 \mathrm{H}), 3.15(\mathrm{~d}, J=21.1,2 \mathrm{H}) \cdot{ }^{13} \mathrm{C}$ NMR $\left(125 \mathrm{MHz}, \mathrm{D}_{2} \mathrm{O}\right) \delta 170.6,123.8(\mathrm{~d}, J=$ 8.8), $121.6(\mathrm{~d}, J=8.8), 62.9(\mathrm{dd}, J=37.3,6.0), 62.4(\mathrm{dd}, J=37.4,5.9), 53.9,33.9(\mathrm{~d}, J=$ 133.8). HRMS (ESI), calcd for $\mathrm{C}_{6} \mathrm{H}_{6} \mathrm{O}_{5} \mathrm{PF}_{6} \mathrm{NaCs}[\mathrm{M}+\mathrm{Na}]^{+} 458.8809$, found 458.8806 .

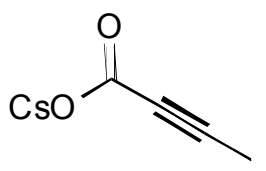

43

Cesium but-2-ynoate (43). ${ }^{17}$ But-2-ynoic acid (15.0 mg, $0.178 \mathrm{mmol}, 1.0$ equiv) was dissolved in diethyl ether $(15.0 \mathrm{~mL})$ and cesium carbonate $(23.3 \mathrm{mg}, 0.071 \mathrm{mmol}, 0.4$ equiv), as a solution in $0.6 \mathrm{~mL}$ water, was added. This mixture was stirred for one hour then was allowed to set for $19 \mathrm{~h}$. Subsequent concentration in vacuo provided $38.4 \mathrm{mg}$ $(100 \%)$ of the cesium carboxylate, which was used without further purification: IR (thin film) 3378, 2918, 2234, 1659, 1578, $1354 \mathrm{~cm}^{-1} ;{ }^{1} \mathrm{H}$ NMR (600 MHz, $\left.\mathrm{D}_{2} \mathrm{O}\right) \delta 1.94(\mathrm{~s}, 3 \mathrm{H})$. ${ }^{13} \mathrm{C}$ NMR $\left(150 \mathrm{MHz}, \mathrm{D}_{2} \mathrm{O}\right) \delta 160.5,83.1,74.9,2.6$. HRMS (ESI), calcd for $\mathrm{C}_{4} \mathrm{H}_{3} \mathrm{O}_{2} \mathrm{Cs}_{2}$ $[\mathrm{M}+\mathrm{Cs}]^{+} 348.8242$, found 348.8236 . 


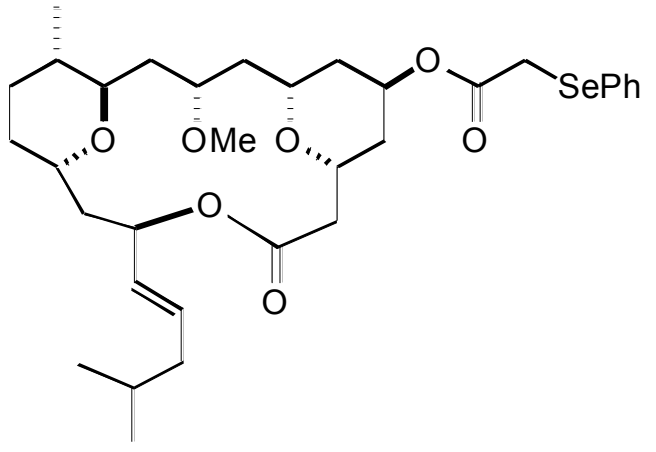

\section{8, $\mathrm{R}=\mathrm{CH}_{2} \mathrm{SePh}$}

Macrocyclic $\alpha$-selenyl ester $\left(38, \mathbf{R}=\mathrm{CH}_{2} \mathrm{SePh}\right)$. To a solution of the macrocyclic bromide 8 (90 mg, $0.179 \mathrm{mmol}, 1.0$ equiv) in anhydrous toluene (5.2 mL) was added cesium 2-(phenylselenyl)acetate (0.50 g, $1.44 \mathrm{mmol}, 8.0$ equiv) and 18-crown-6 (1.13 g, $4.30 \mathrm{mmol}, 24$ equiv). This mixture was heated at $110^{\circ} \mathrm{C}$ in a sealed tube for $16 \mathrm{~h}$. After cooling to $23{ }^{\circ} \mathrm{C}$, the mixture was diluted with dichloromethane $(25 \mathrm{~mL})$ and water $(25$ $\mathrm{mL}$ ). The layers were separated and the aqueous layer was extracted with dichloromethane $(3 \times 25 \mathrm{~mL})$. The combined organic layers were washed with brine $(1 \times$ $25 \mathrm{~mL}$ ), dried over anhydrous sodium sulfate, and concentrated in vacuo. The crude oil purified by flash chromatography (10-50\% ethyl acetate/hexanes) to provide $89.4 \mathrm{mg}$ $(78 \%)$ of the ester 38, $\mathbf{R}=\mathbf{C H}_{2} \mathbf{S e P h}$ as a light yellow oil: $[\alpha]^{23}{ }_{\mathrm{D}}+54.7(c=2.1$, chloroform), IR (thin film) 2954, 2925, 2868, 1738, 1263, $1081 \mathrm{~cm}^{-1} ;{ }^{1} \mathrm{H}$ NMR (600 $\left.\mathrm{MHz}, \mathrm{CDCl}_{3}\right) \delta 7.62-7.55(\mathrm{~m}, 2 \mathrm{H}), 7.34-7.29(\mathrm{~m}, 3 \mathrm{H}), 5.72(\mathrm{dt}, J=14.7,7.6,1 \mathrm{H}), 5.44-$ $5.33(\mathrm{~m}, 2 \mathrm{H}), 5.17(\mathrm{t}, J=2.5,1 \mathrm{H}), 4.02-3.94(\mathrm{~m}, 1 \mathrm{H}), 3.90(\mathrm{~d}, J=11.6,1 \mathrm{H}), 3.65-3.47$ $(\mathrm{m}, 5 \mathrm{H}), 3.35(\mathrm{~s}, 3 \mathrm{H}), 2.50-2.39(\mathrm{~m}, 2 \mathrm{H}), 2.38-2.24(\mathrm{~m}, 1 \mathrm{H}), 1.98-1.83(\mathrm{~m}, 4 \mathrm{H}), 1.82-$ $1.40(\mathrm{~m}, 10 \mathrm{H}), 1.39-1.25(\mathrm{~m}, 2 \mathrm{H}), 1.18(\mathrm{~d}, J=7.1,3 \mathrm{H}), 1.07-0.97(\mathrm{~m}, 1 \mathrm{H}), 0.87(\mathrm{~d}, J=$ 
6.6, 3H), $0.87(\mathrm{~d}, J=6.6,3 \mathrm{H}) .{ }^{13} \mathrm{C} \mathrm{NMR}\left(125 \mathrm{MHz}, \mathrm{CDCl}_{3}\right) \delta$ 170.0, 169.6, 133.3, 132.6, $130.3,129.5,128.2,73.9,73.6,71.1,70.1,69.8,69.2,63.3,57.5,43.4,43.2,41.8,39.3$, 35.8, 35.7, 35.5, 35.4, 31.2, 28.4, 28.2, 27.4, 24.5, 22.5, 18.5. HRMS (ESI), calcd for $\mathrm{C}_{33} \mathrm{H}_{48} \mathrm{O}_{7} \mathrm{SeNa}[\mathrm{M}+\mathrm{Na}]^{+}$659.2466, found 659.2492.

1 Pangborn, A. B.; Giardello, M. A.; Grubbs, R. H.; Rosen, R. K.; Timmers, F. J. Organometallics, 1996, 15, 1518-1520.

2 Still, C. W.; Kahn, M.; Mitra, A. J. Org. Chem. 1978, 43, 2923-2925.

3 Patterson, B. D. Masters Thesis, The University of California-Irvine, Irvine, CA, 2005.

4 De Vicente-Fidalgo, J. Post-doctoral Report. The University of California-Irvine, Irvine, CA, 2005.

5 La Cruz, T. E.; Rychnovsky, S. D. Org. Lett. 2005, 7, 1873-1875.

6 Scholl, M.; Ding, S.; Lee, C. W.; Grubbs, R. H. Org. Lett. 1999, 1, 953.

7 (a) Paterson, I.; Tudge, M. Angew. Chem., Int. Ed. 2003, 42, 343-347. (b) Paterson, I.; Tudge, M. Tetrahedron 2003, 59, 6833-6849.

8 Kourouli, T.; Kefalas, P.; Ragoussis, N.; Ragoussis, V. J. Org. Chem. 2002, 67, 46154618. 
9 Synthesis of the pyrrolidinol ligands: (a) Nikolic, N. A., Beak, P. Org. Synth., Coll. Vol. 9, 391-397. (b) Xavier, L. C.; Mohan, J. J.; Mathre, D. J.; Thompson, A. S.; Carroll, J. D.; Corley, E. G.; Desmond, R. Org. Synth., Coll. Vol. 9, 676-689. Synthesis of the catalyst: (c) Mathre, D. J.; Jones, T. K.; Xavier, L. C.; Blacklock, T. J.; Reamer, R. A.; Mohan, J. J.; Turner Jones, E. T.; Hoogsteen, K.; Baum, M. W.; Grabowski, E. J. J. J. Org. Chem. 1991, 56, 751-762. (d) Mathre, D. J.; Thompson, A. S.; Douglas, A. W.; Hoogsteen, K.; Carroll, J. D.; Corley, E. G.; Grabowski, E. J. J. J. Org. Chem. 1993, 58, 2880-2888.

10 This Mosher's derivative was prepared on small scale by the following procedures:

(a) Ward, D. E.; Rhee, C. K. Tetrahedron Lett. 1991, 32, 7165-7166. (b) Rychnovsky, S. D.; Skalitzky, D. J.; Pathirana, C.; Jensen, P. R.; Fenical, W. J. Am. Chem. Soc. 1992, $114,671-677$.

11 Bennett, F.; Knight, D. W.; Fenton, G. J. Chem. Soc., Perkin Trans. 1. 1991, 133140.

12 Clive, D. L. J.; Murthy, K. S.; Keshava, W.; Andrew, G. H.; Prasad, J. S.; Da Silva, G. V. J.; Majewski, M.; Anderson, P. C.; Evans, C. F.; Haugen, R. D.; Heerze, L. D.; Barrie, J. R. J. Am. Chem. Soc. 1990, 112, 3018-3028.

13 Jones' reagent was freshly-prepared by dissolving $0.69 \mathrm{~g} \mathrm{CrO}_{3}$ in $0.56 \mathrm{~mL} \mathrm{H}_{2} \mathrm{SO}_{4}$ and 2.0 mL water: Shimokawa, J.; Ishiwata, T.; Shirai, K.; Koshino, H.; Tanatani, A.; Nakata, T.; Hashimoto, Y.; Nagasawa, K. Chem. Eur. J. 2005, 11, 6878-6888. 
14 Hornberger, K. R.; Hamblett, C. L.; Leighton, J. L. J. Am. Chem. Soc. 2000, 122, 12894-12895.

15 (a) Wang, Y.; Janjic, J.; Kozmin, S. A. Pure Appl. Chem. 2005, 77, 1161-1169. (b) Wang, Y.; Janjic, J.; Kozmin, S. A. J. Am. Chem. Soc. 2002, 124, 13670-13671.

16 Spectral data is included for $\mathbf{3 4}$ because we suspect a typographical error in the previously reported supporting information.

17 For a procedure for the preparation of cesium carboxylates, see: Chen, B.; Zeng, X. B.; Baumeister, U.; Diele, S.; Ungar, G.; Tschierske, C. Angew. Chem., Int. Ed. 2004, $43,4621-4625$. 


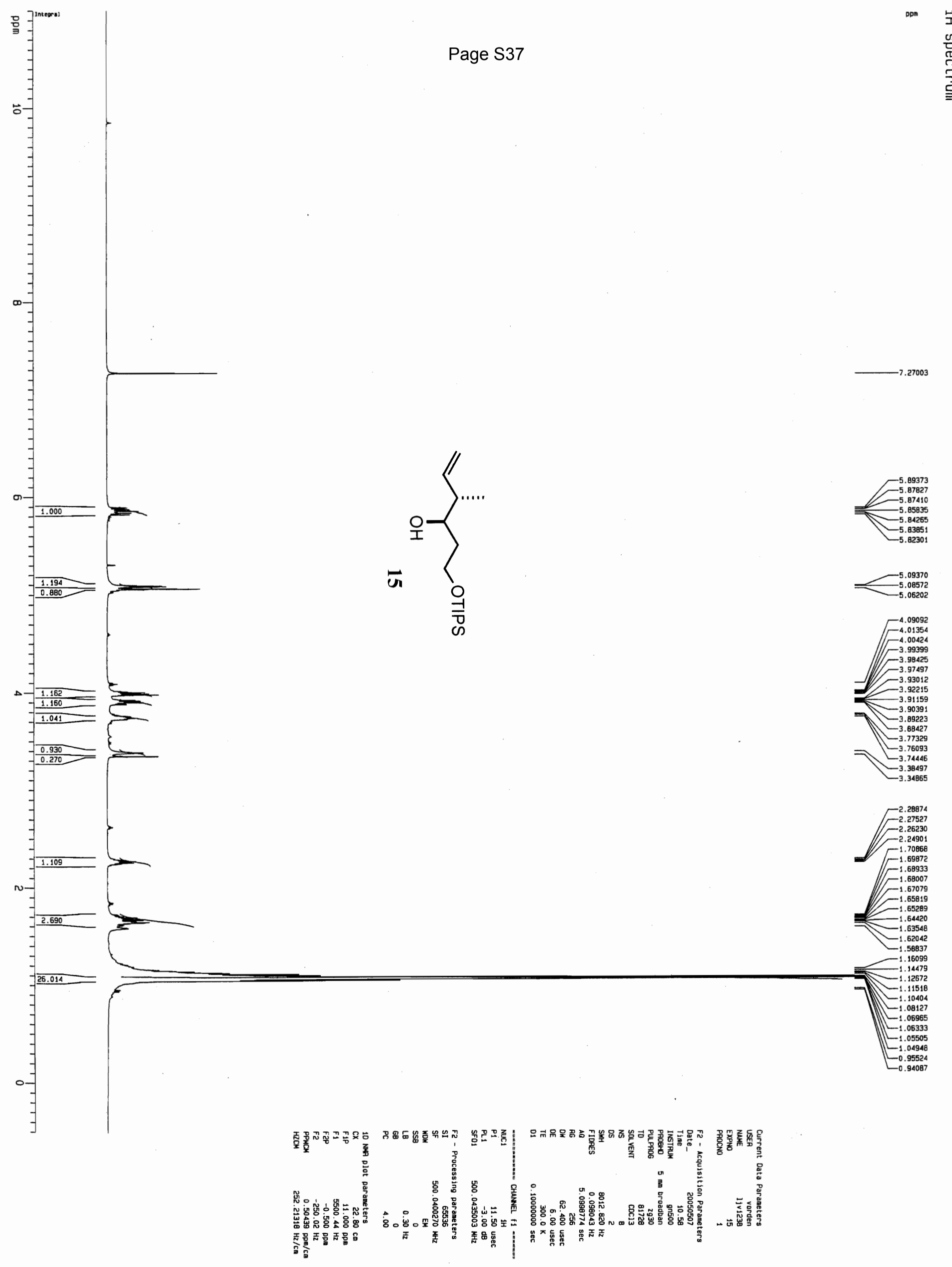




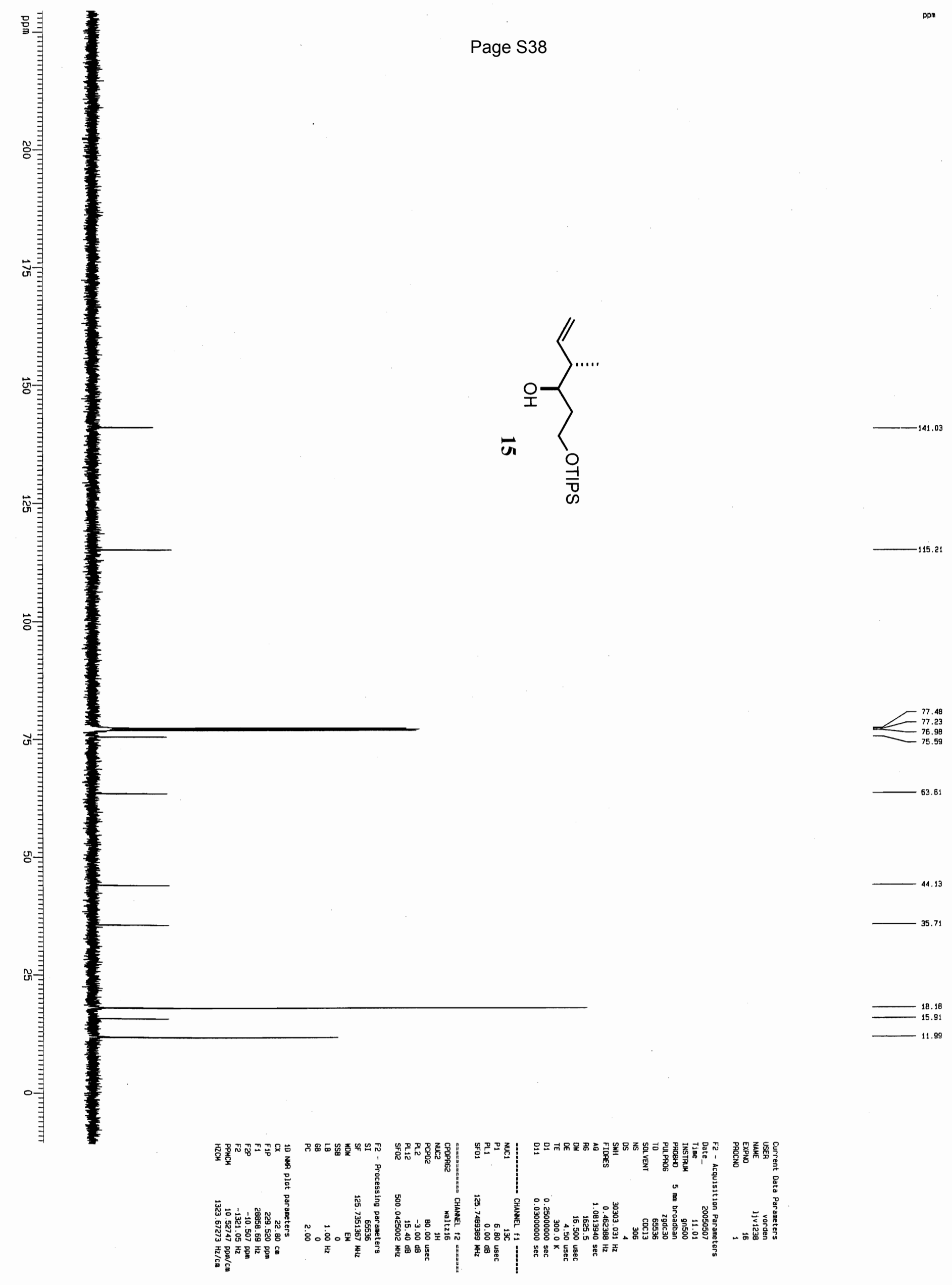




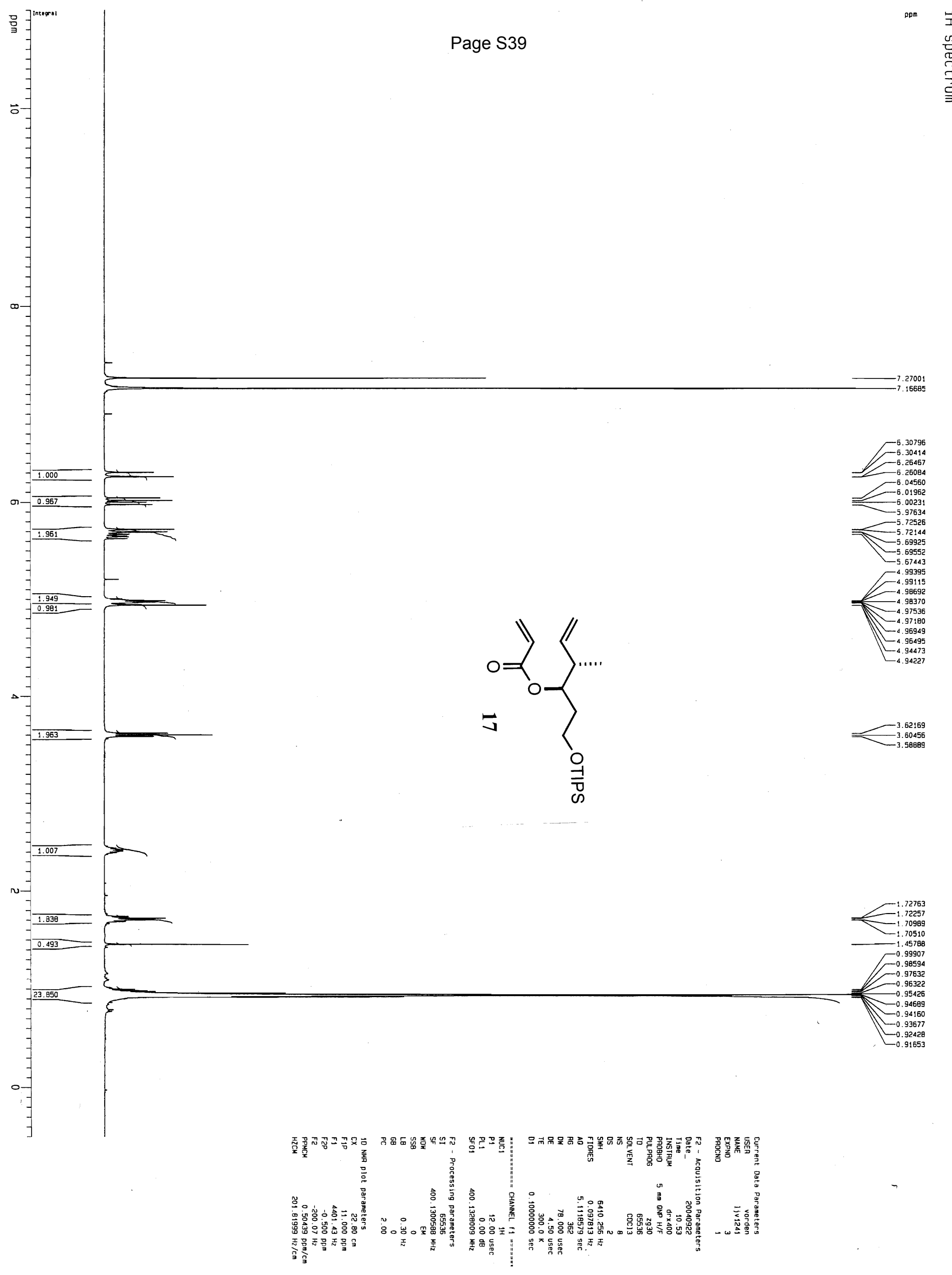




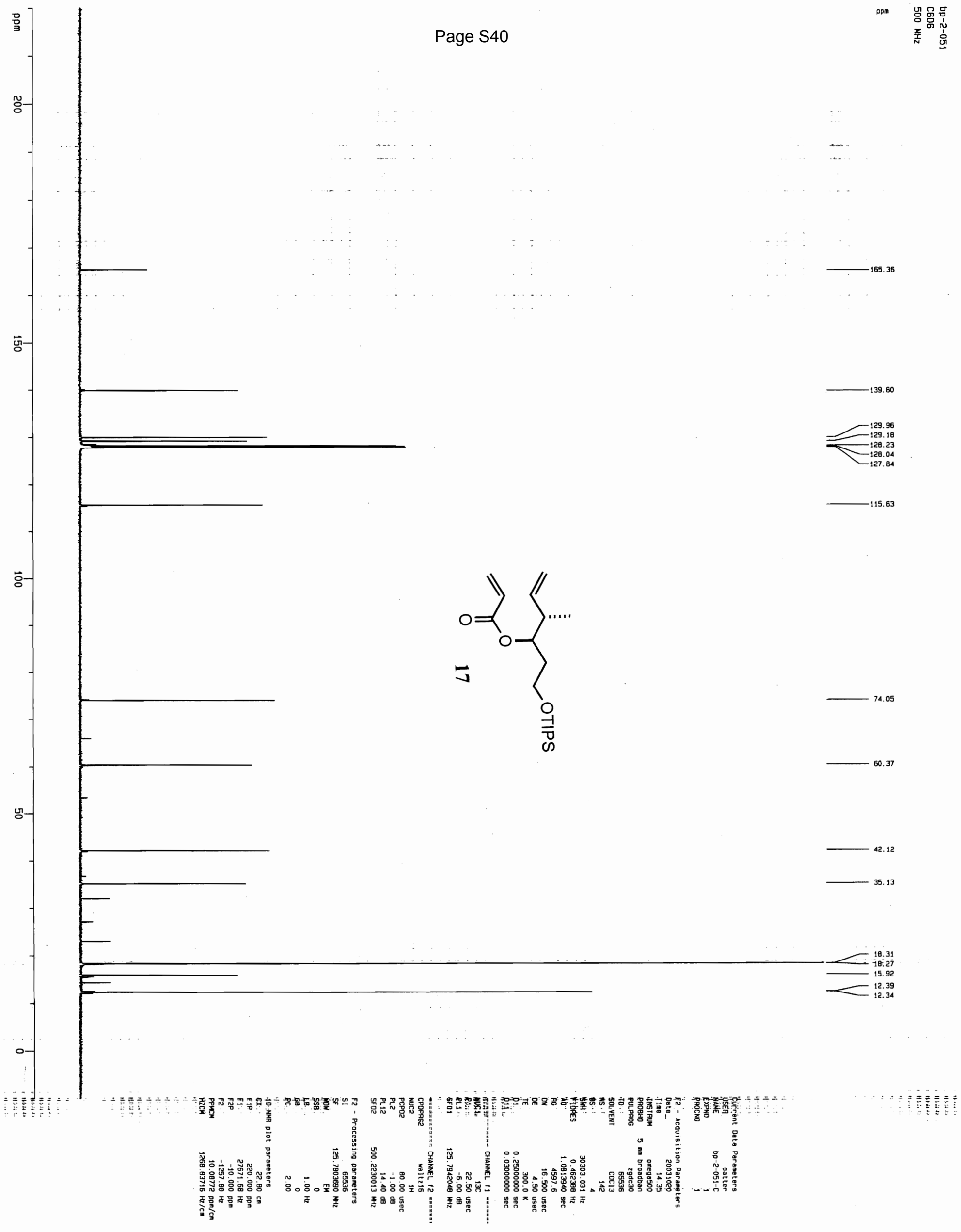



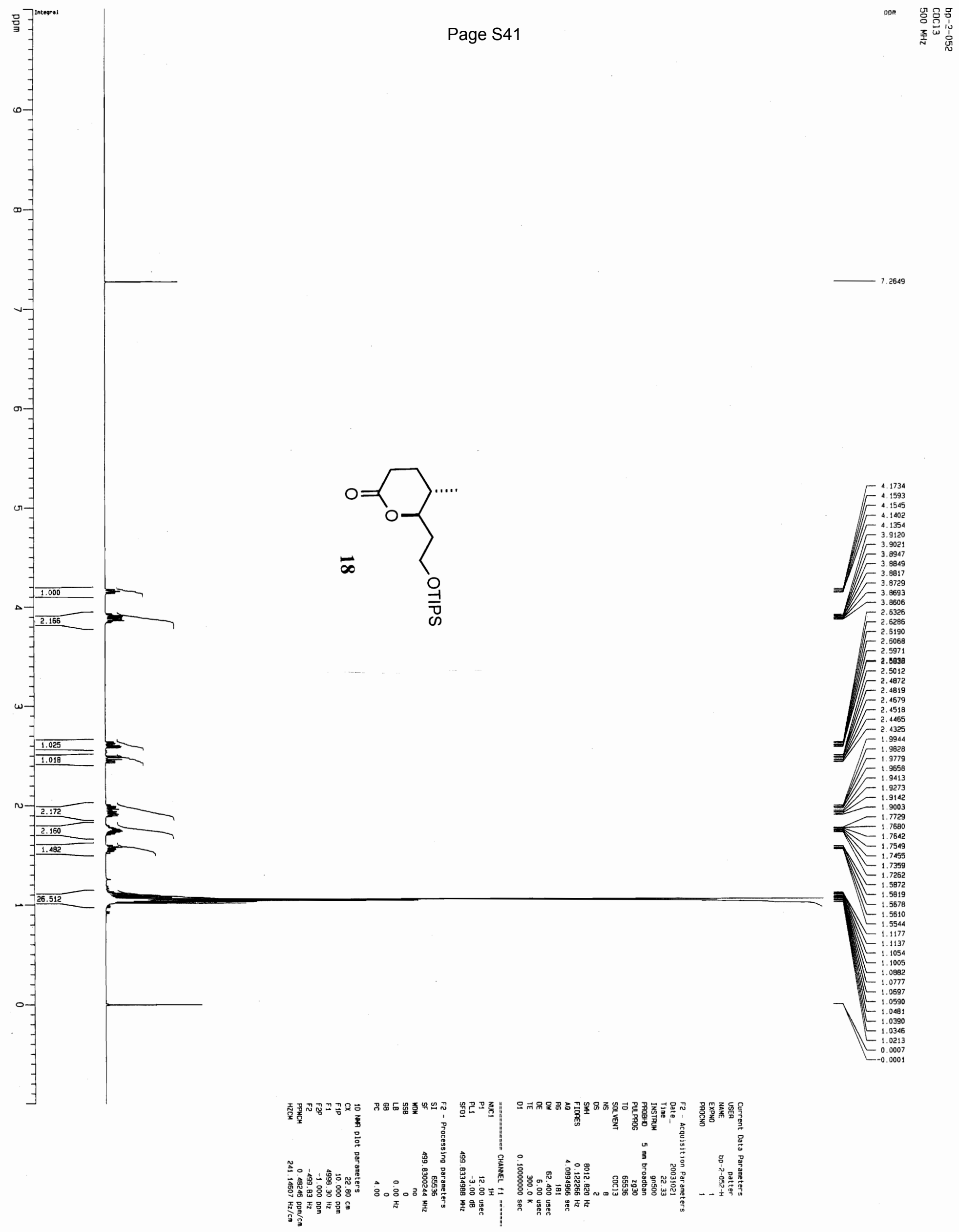


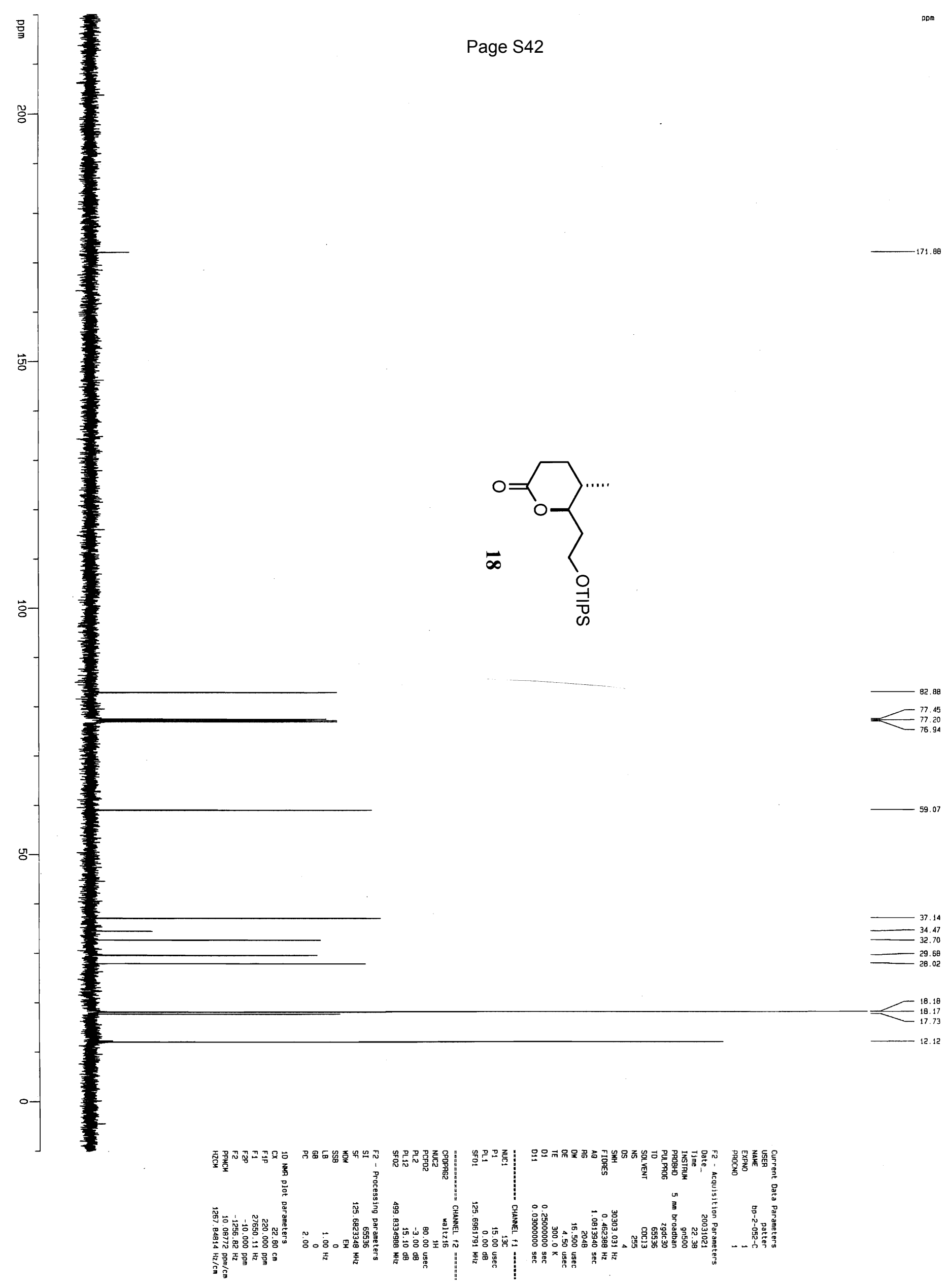




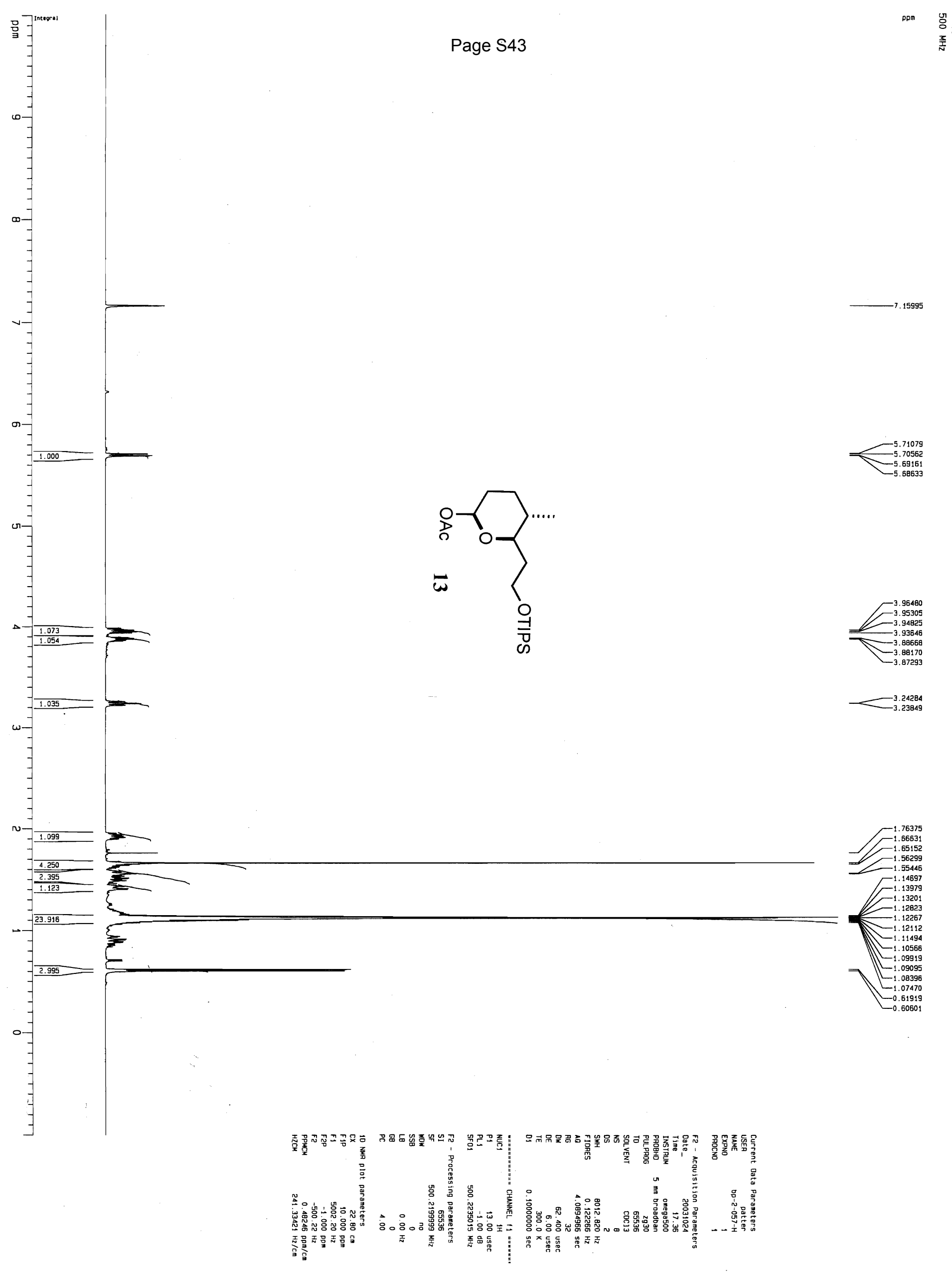



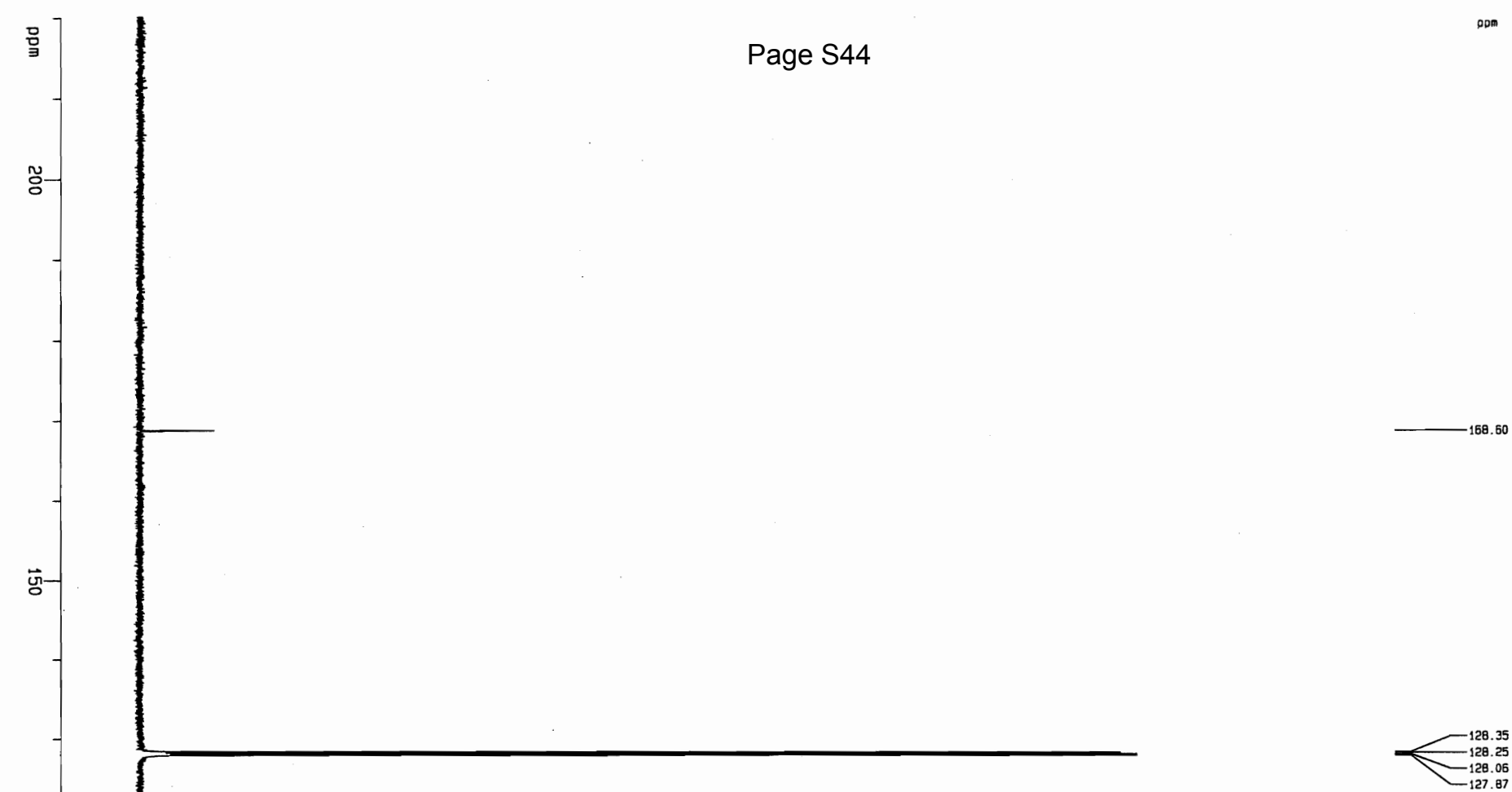

$=$
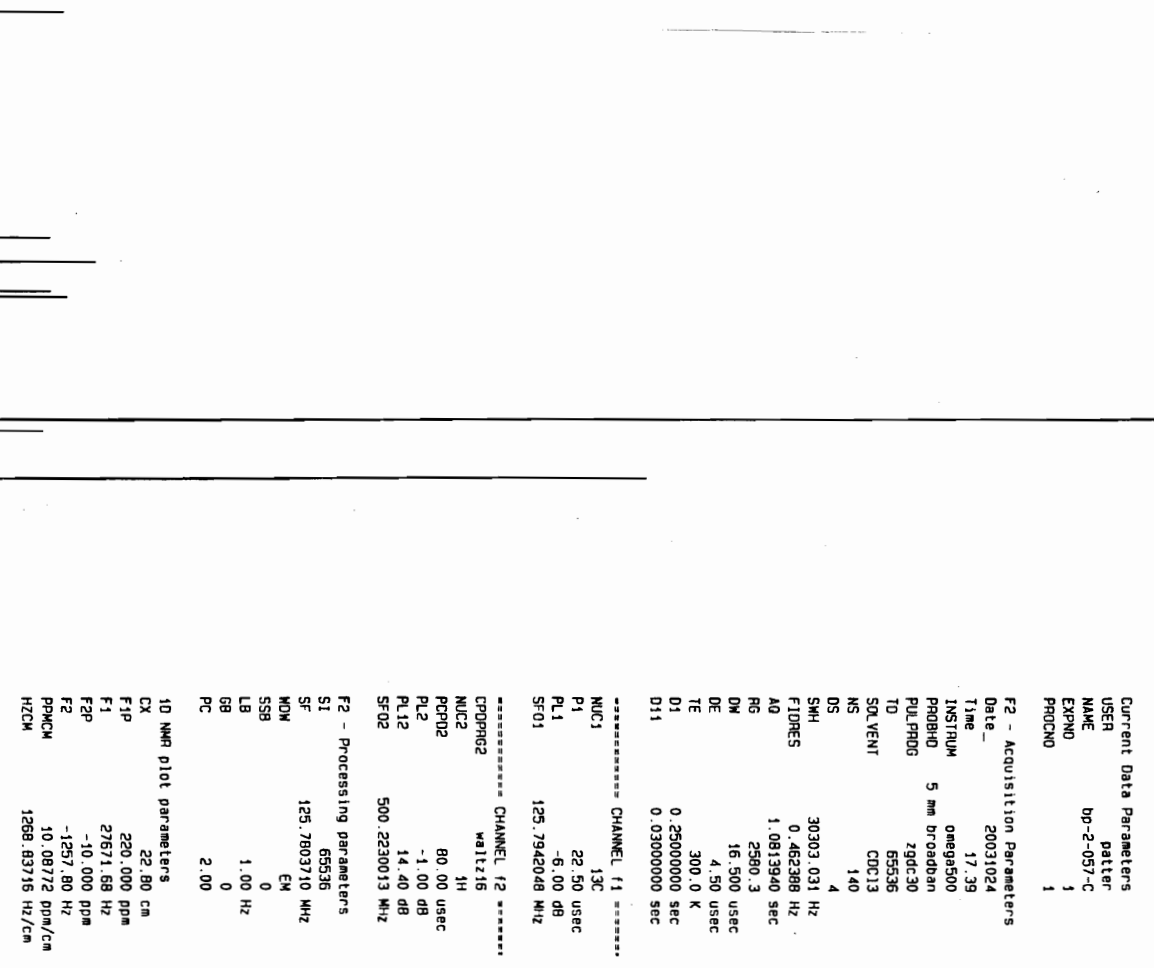


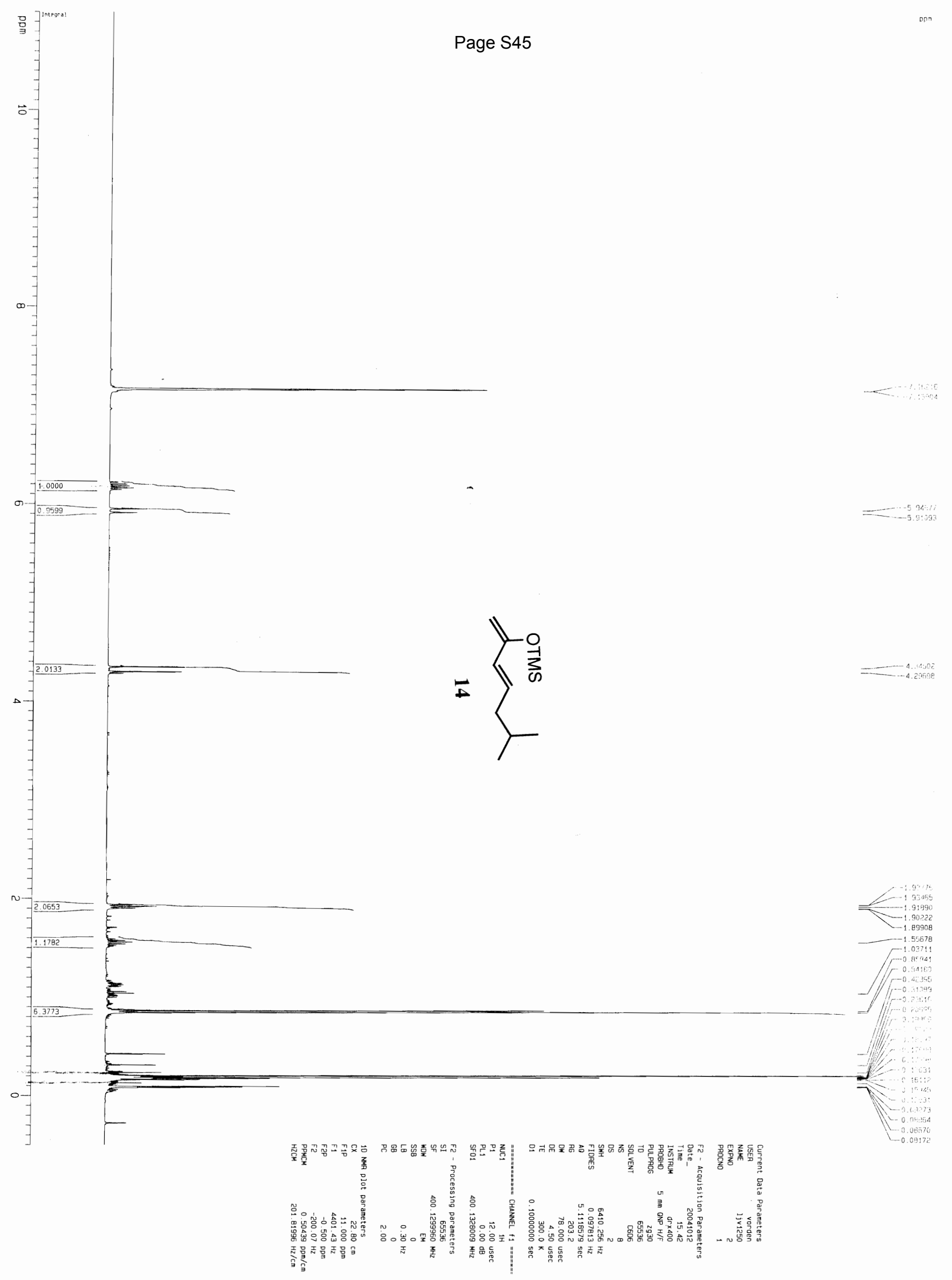




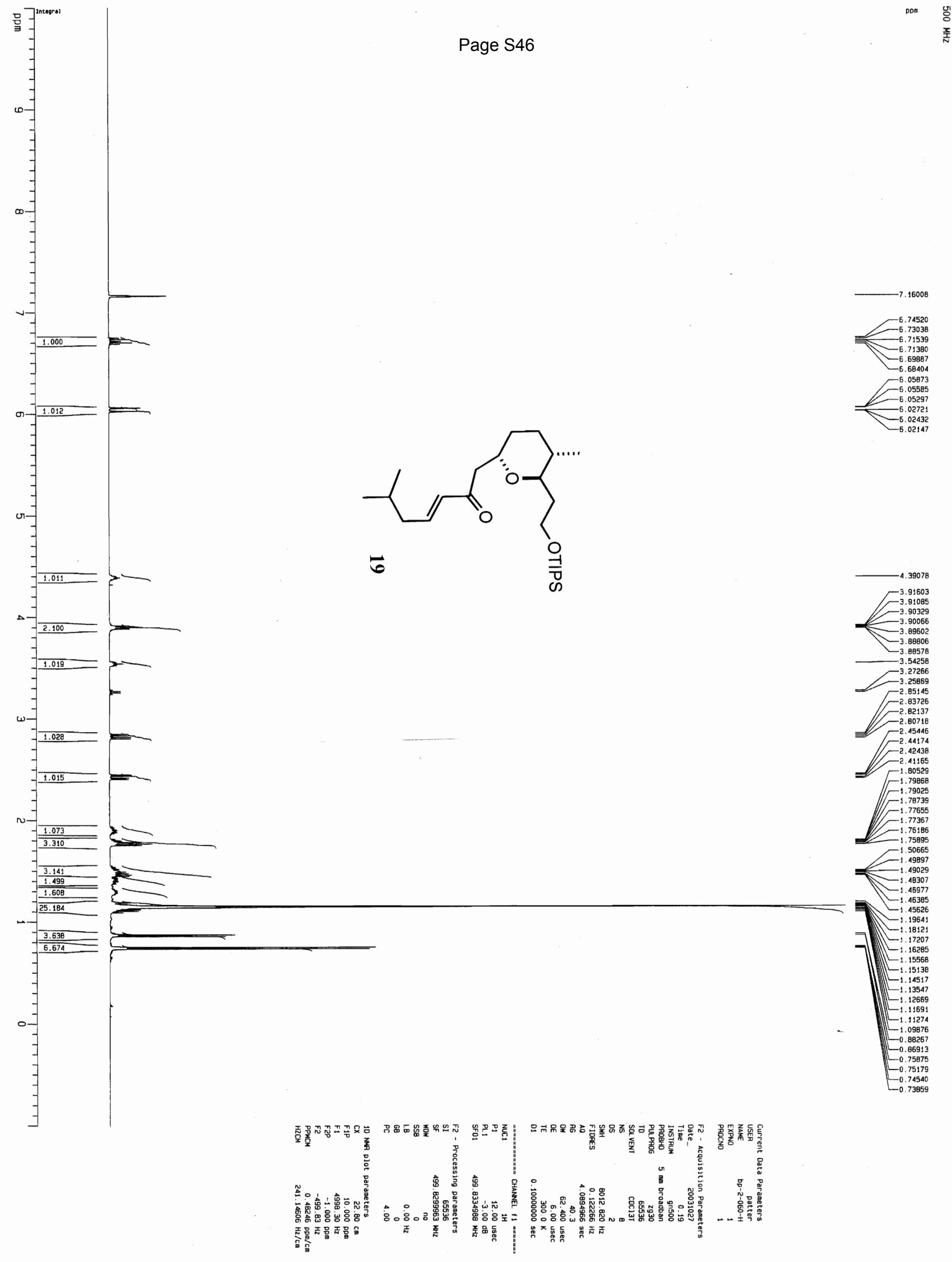




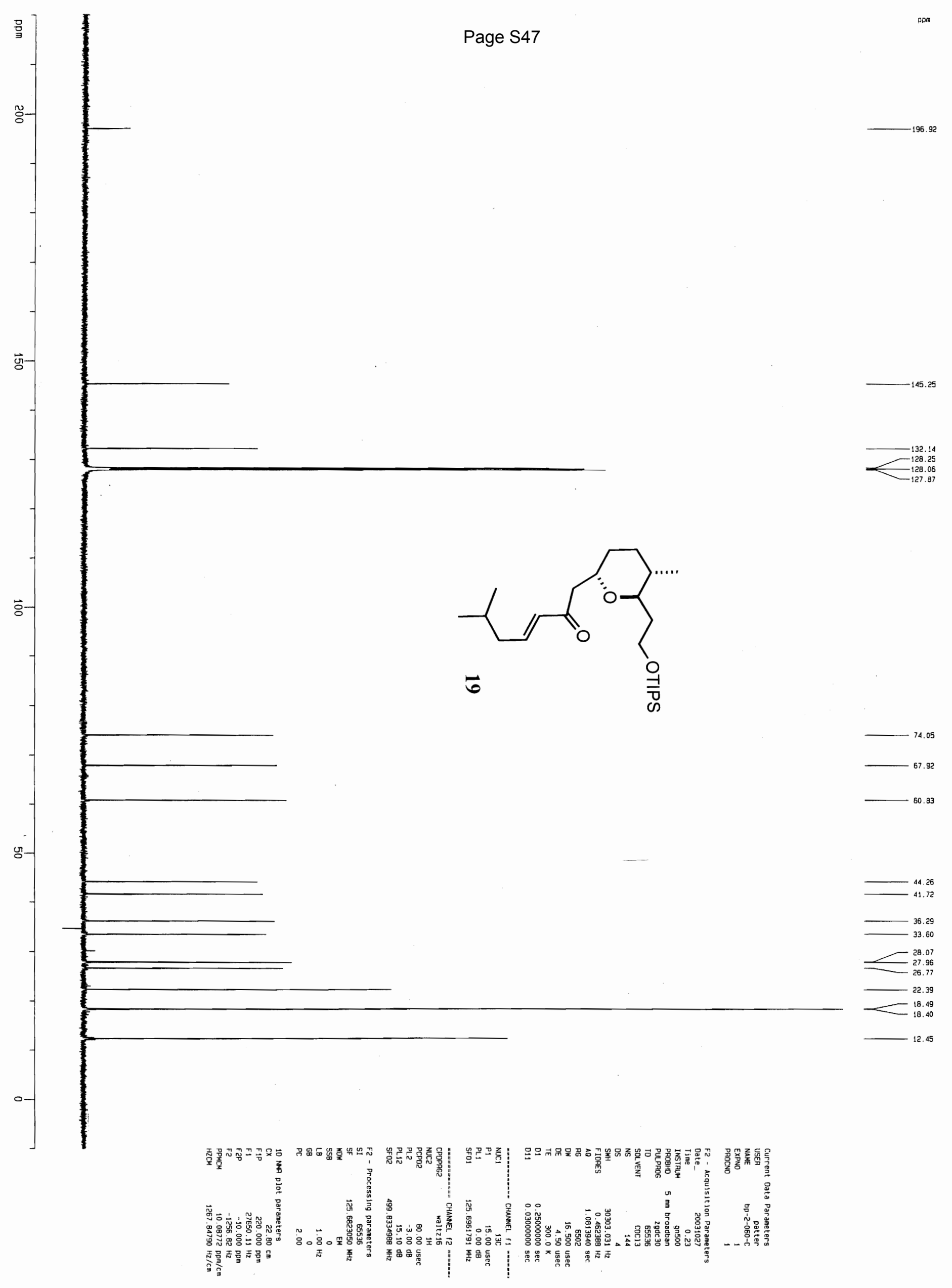




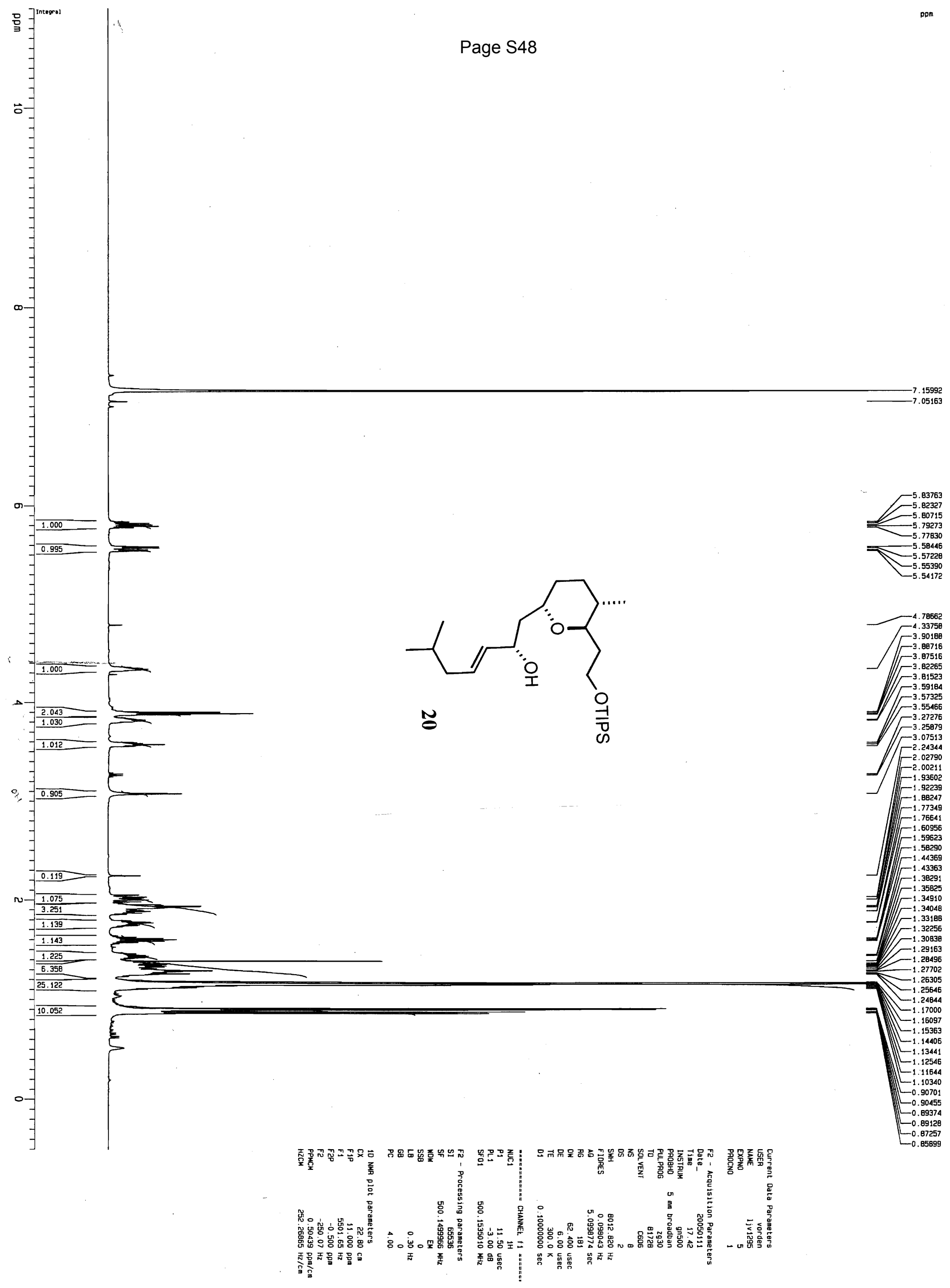




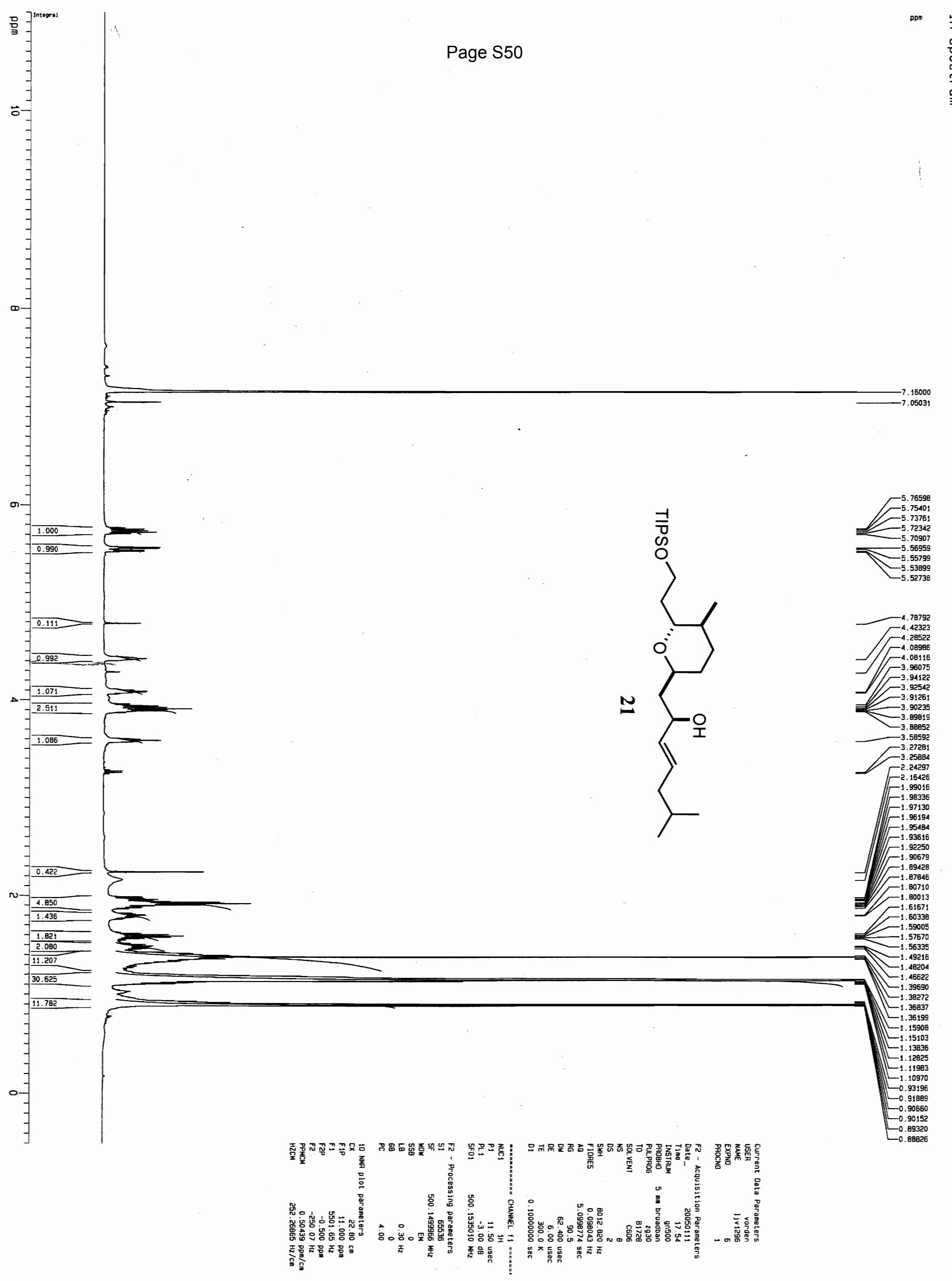




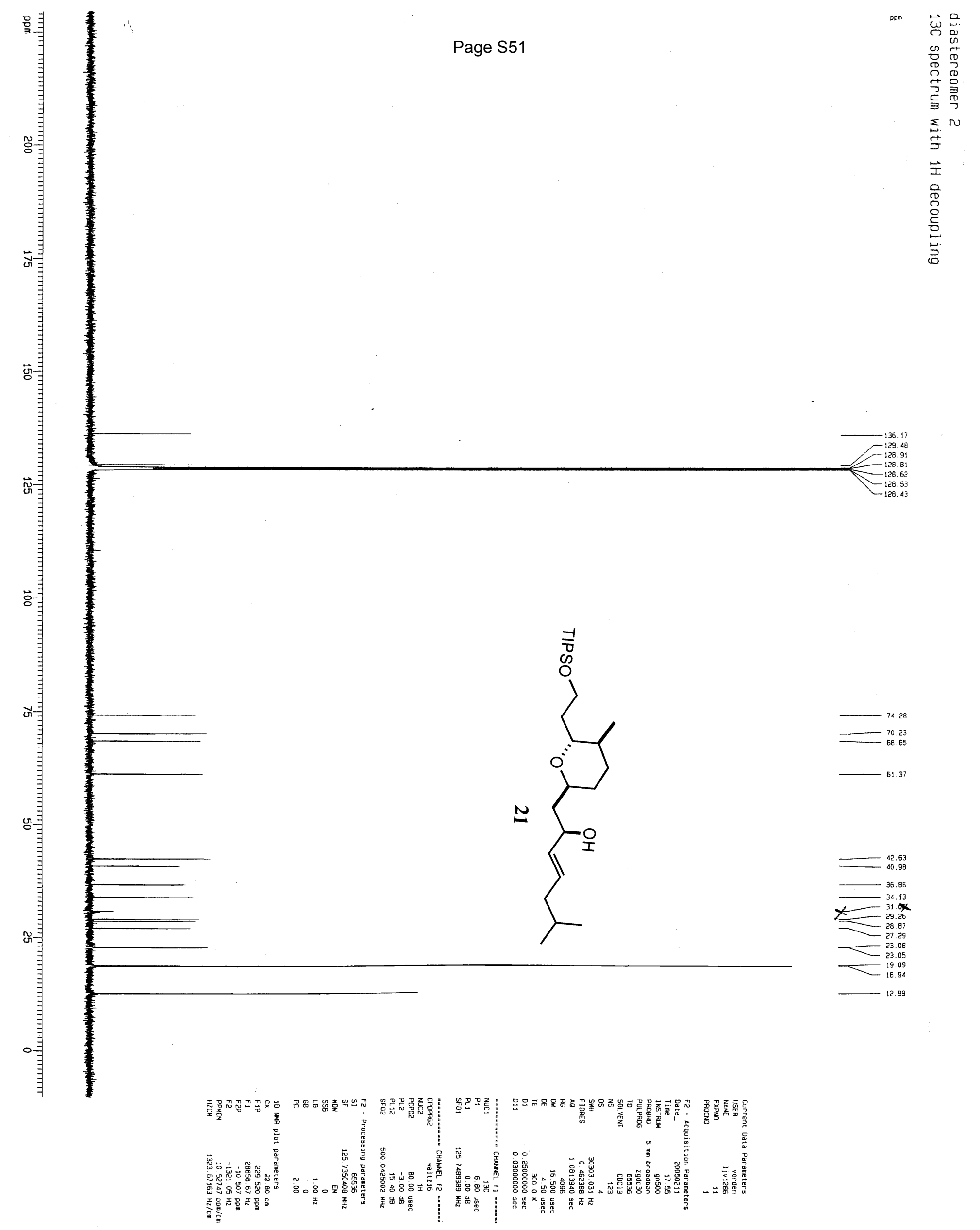




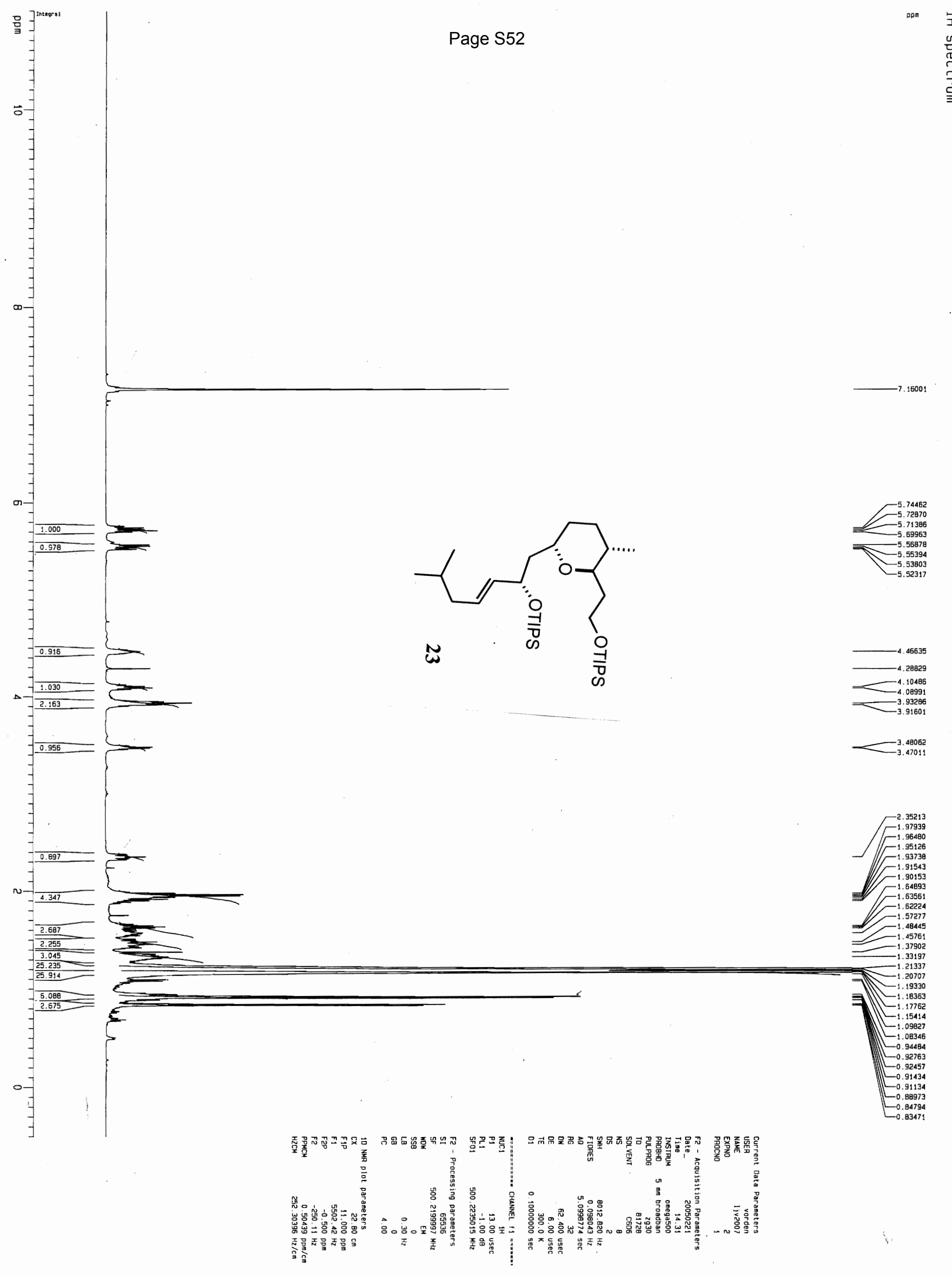



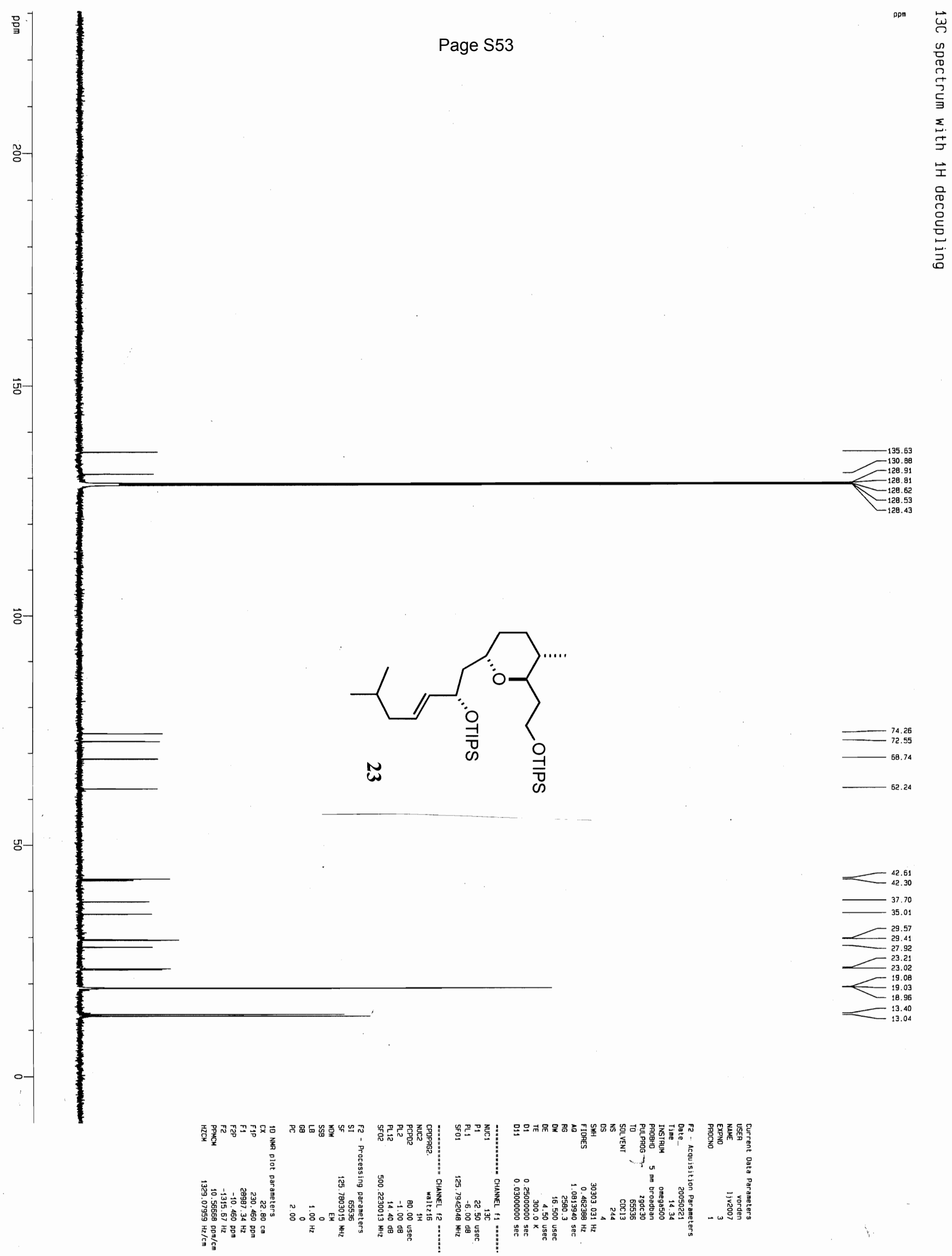

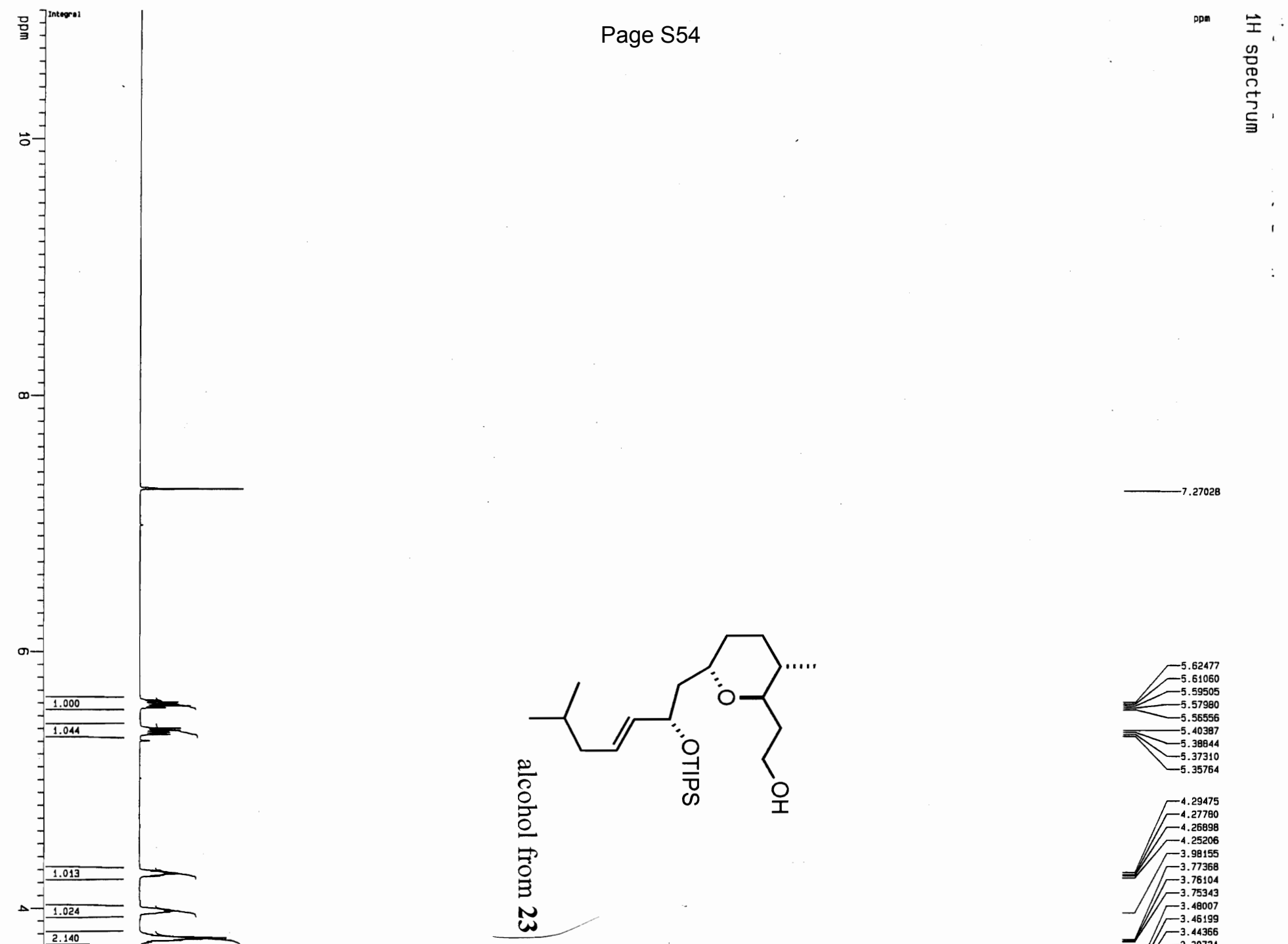

N

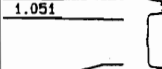

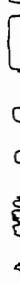

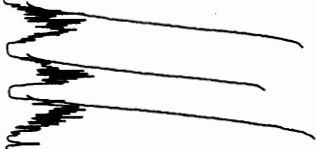



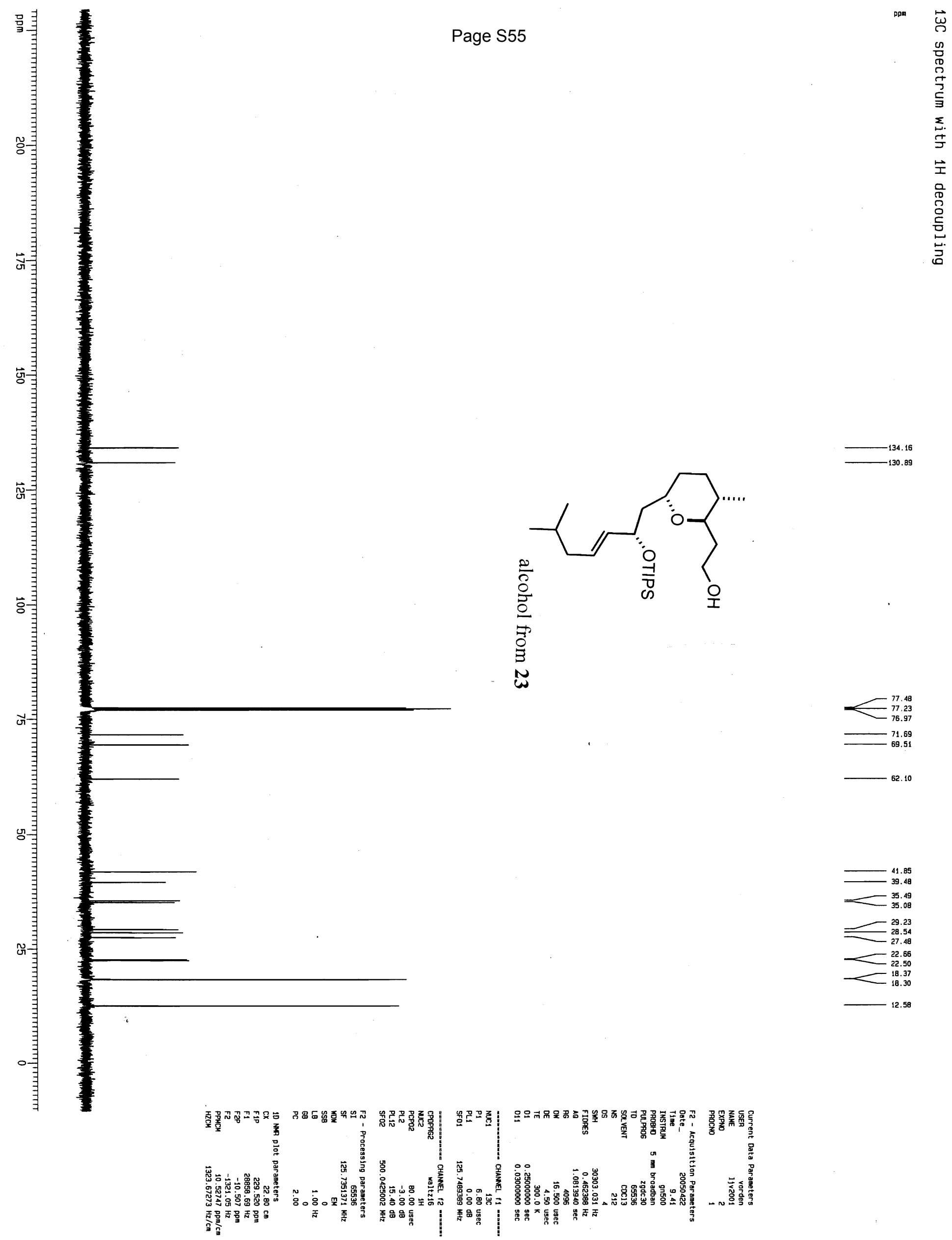


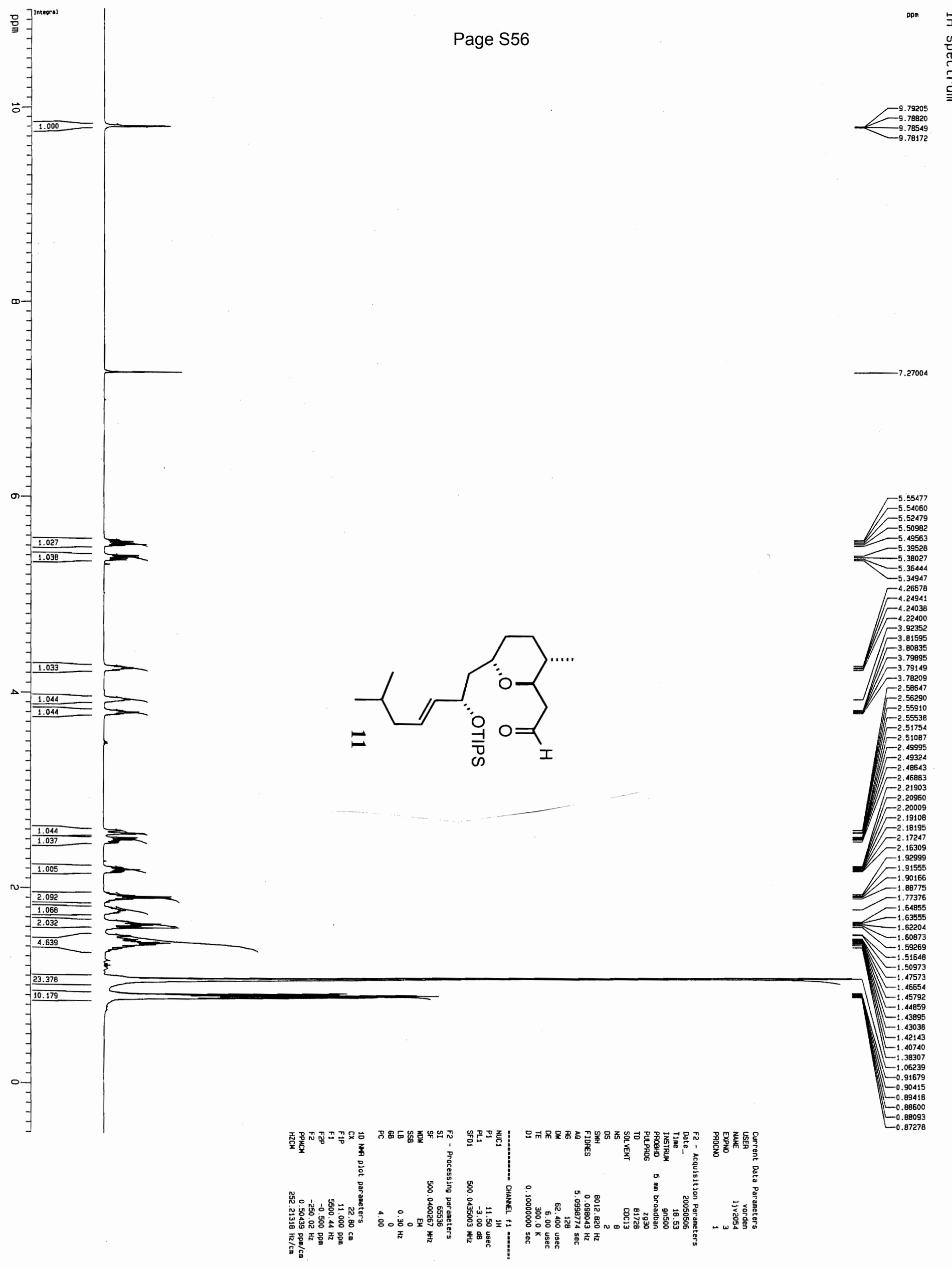




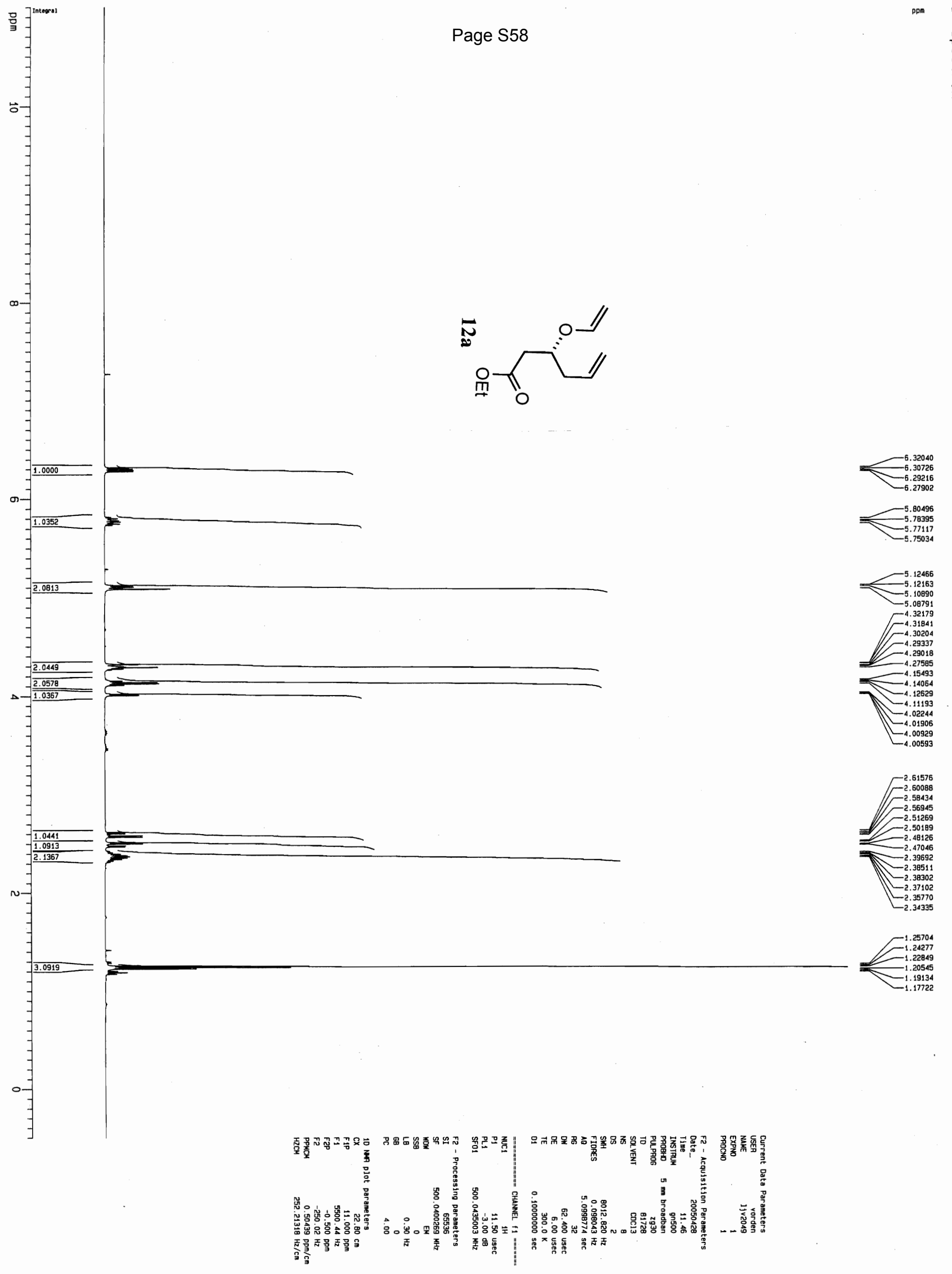



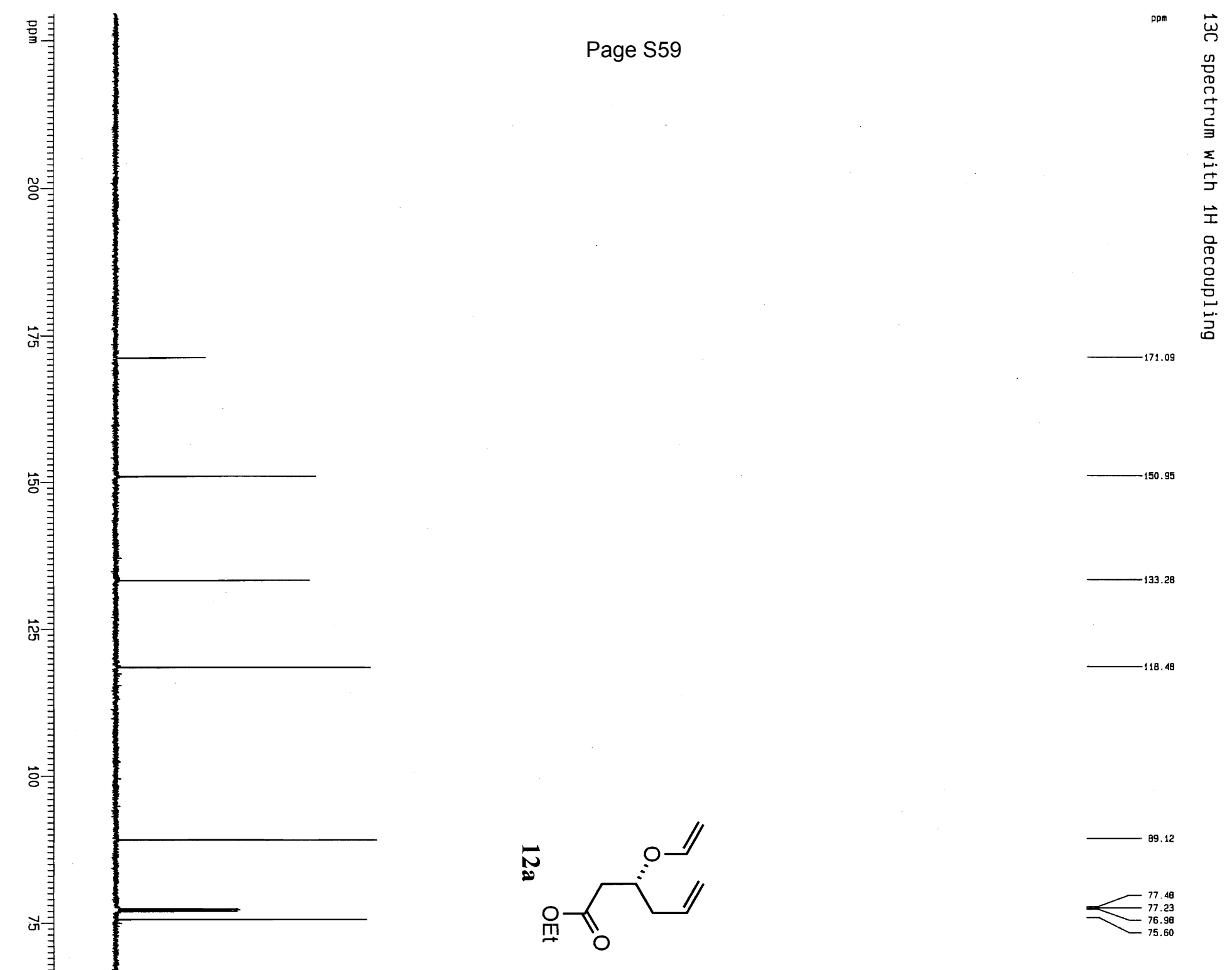

芯
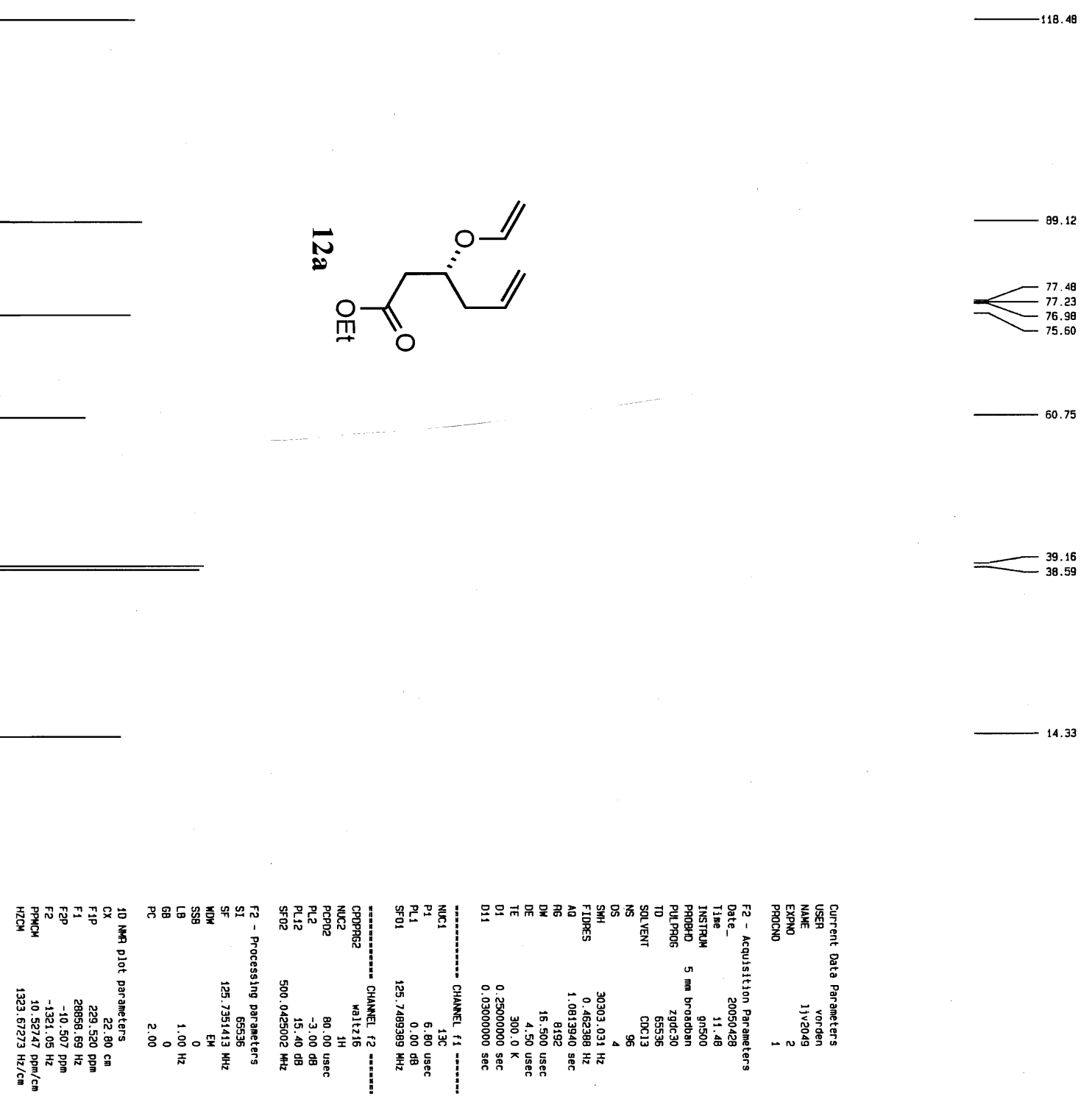


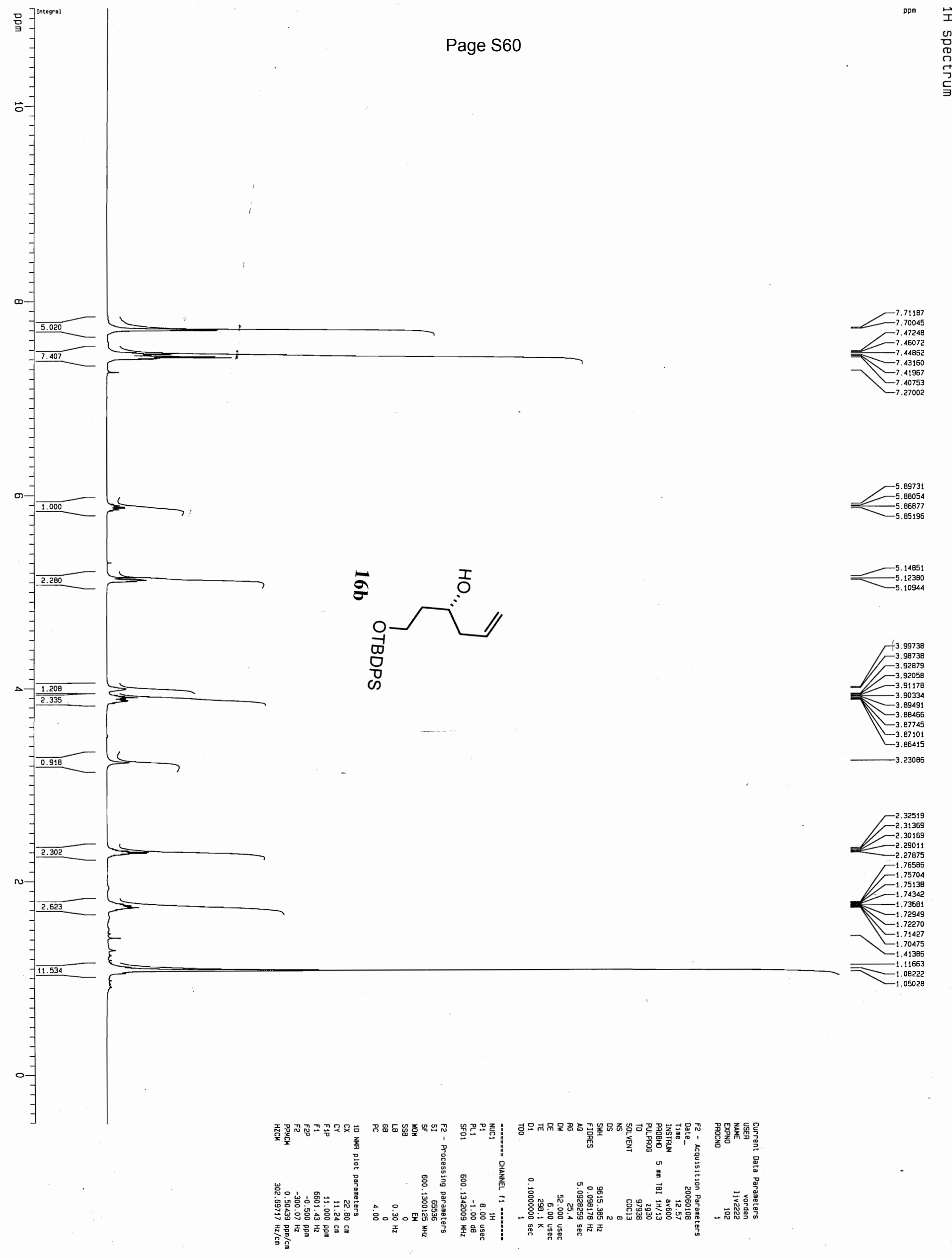




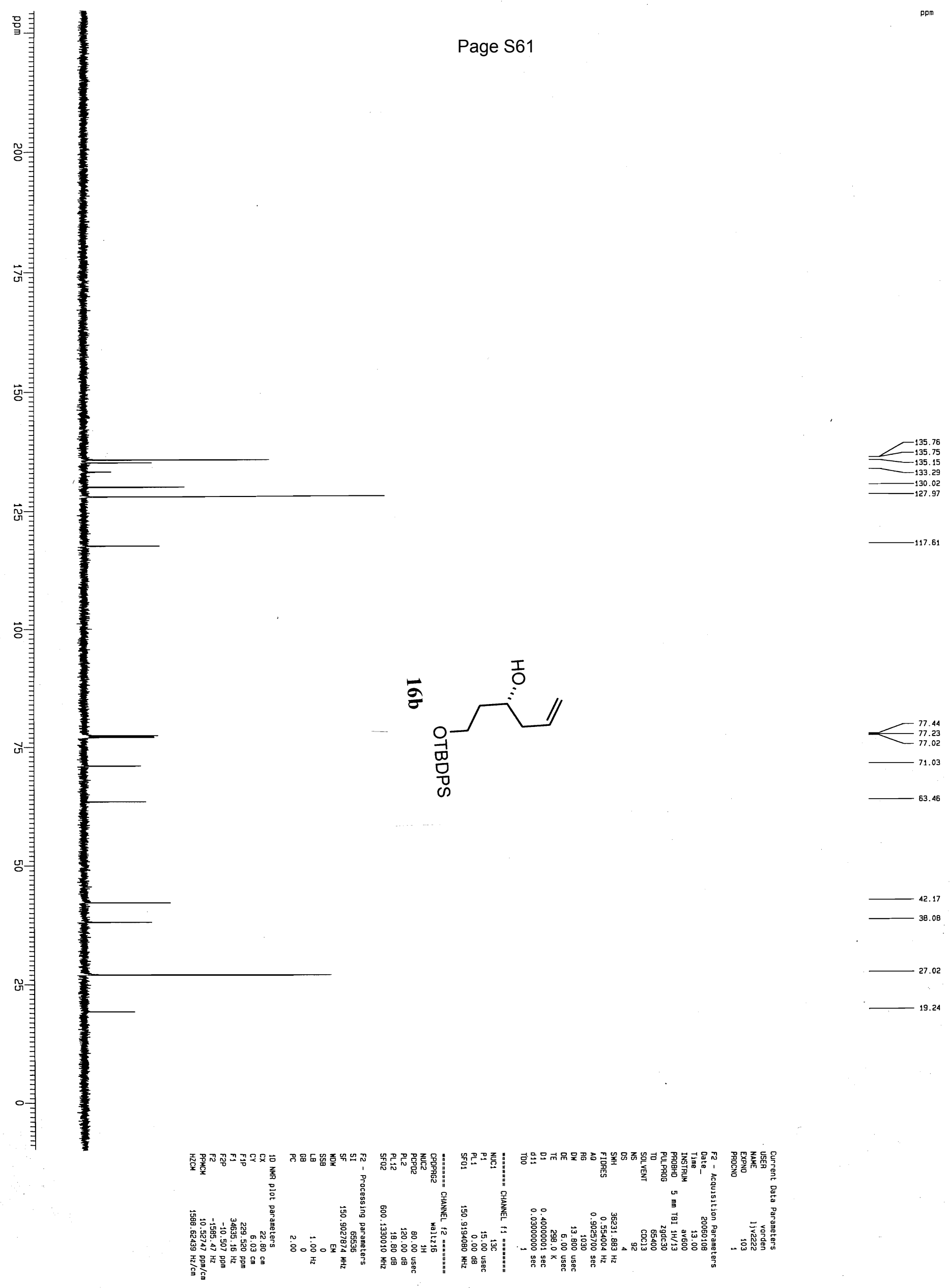

$\bar{\sigma}$ 


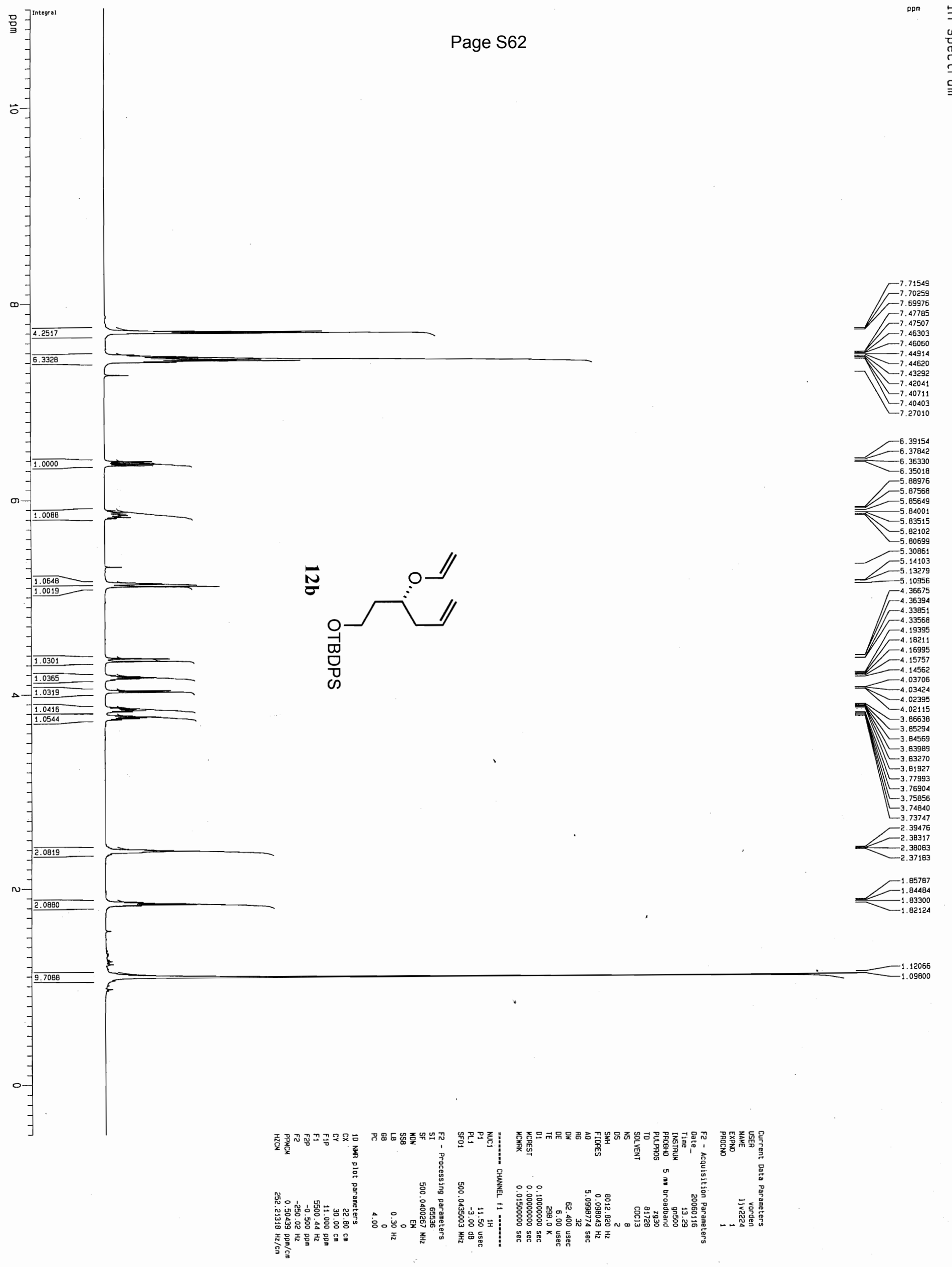




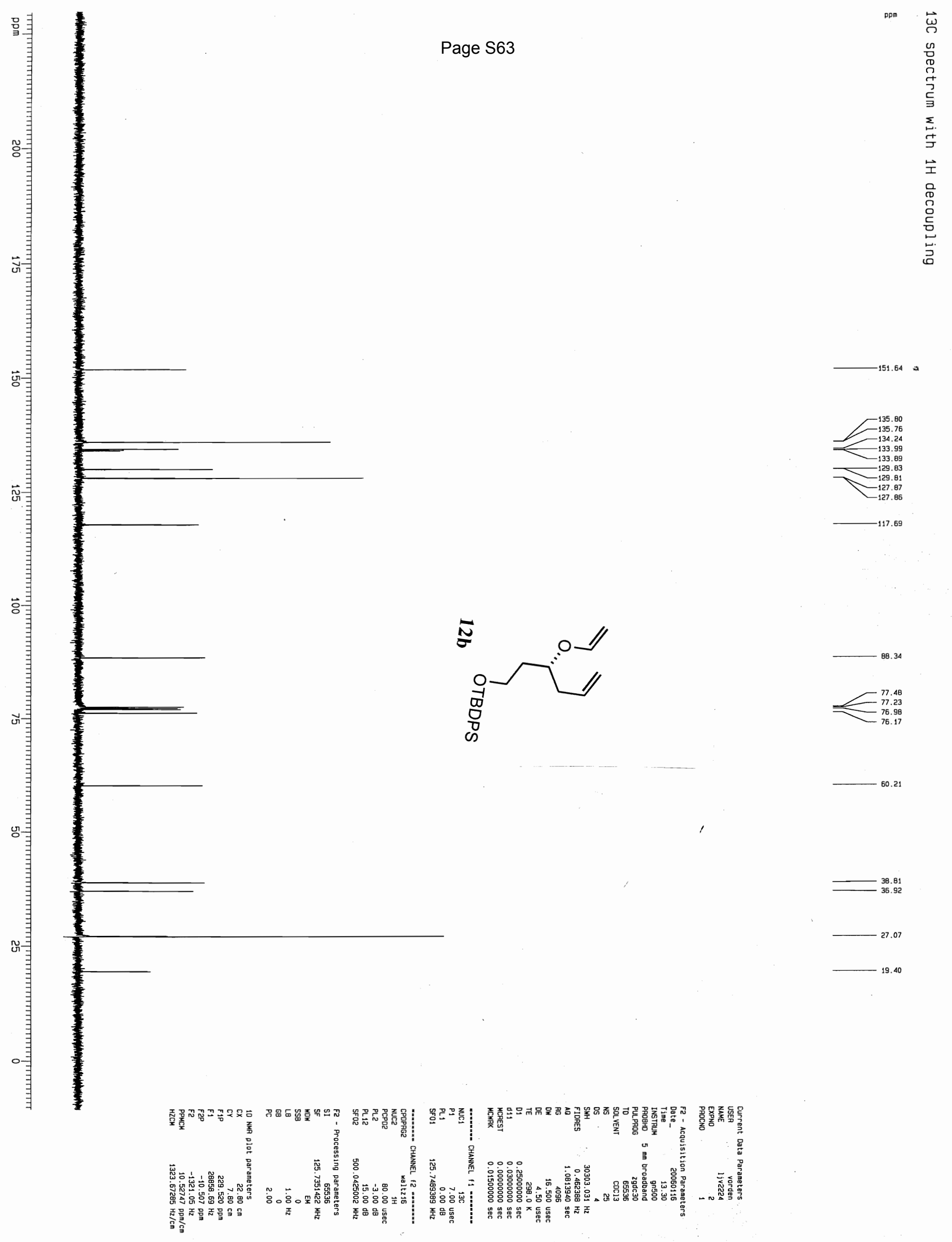




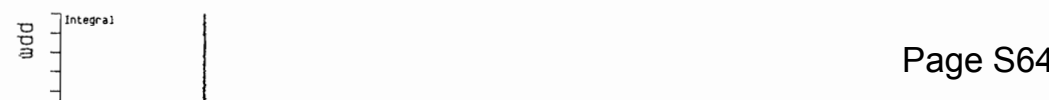

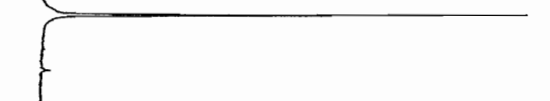

$\longrightarrow .27009$
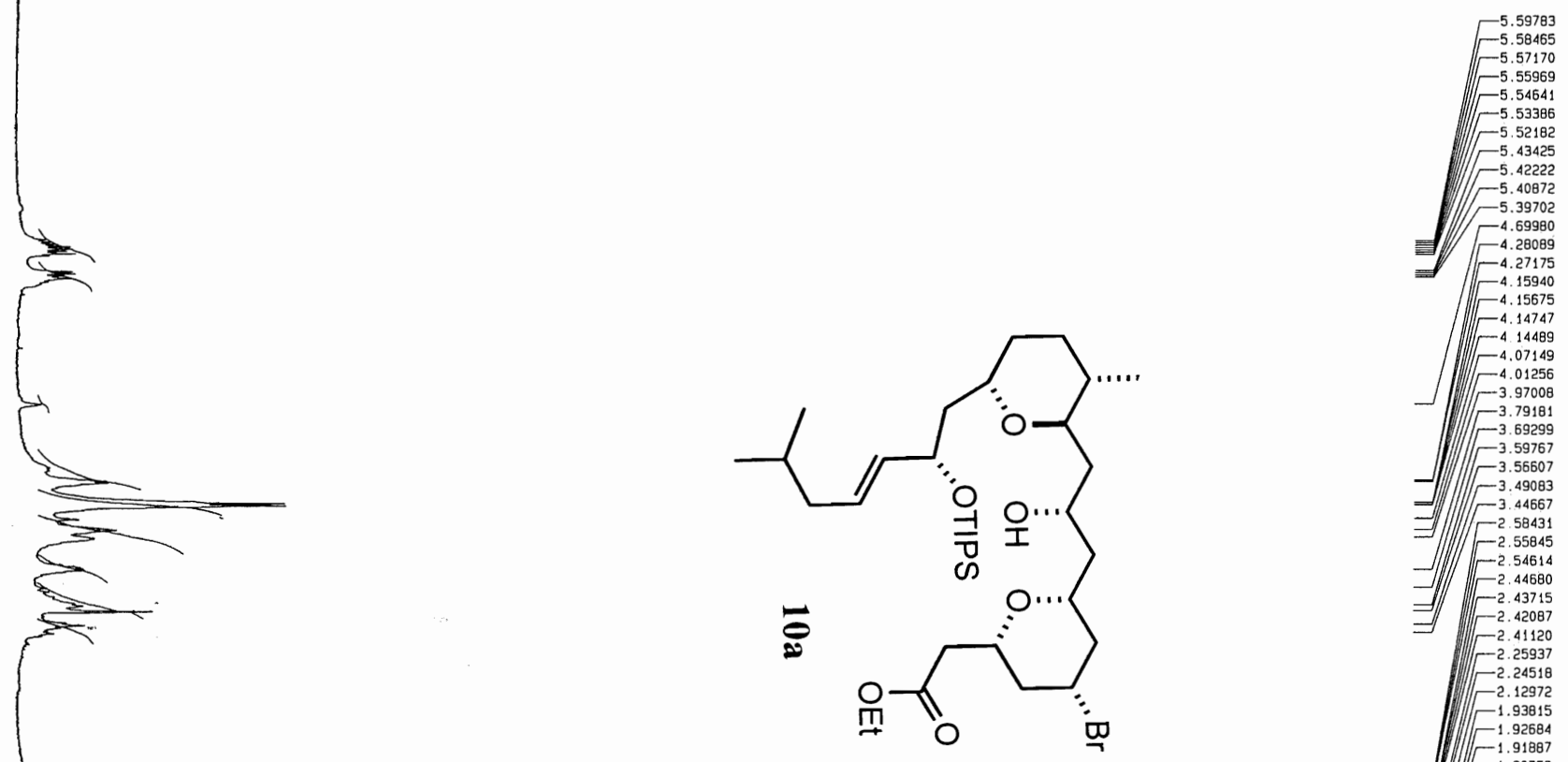

$F_{-4.27775}^{4.27940}$

$-4.15675$

$\left[\begin{array}{rl}4.41477 \\ -4.4489 \\ -4.07149\end{array}\right.$

$F^{4.01250}$

姫.

$-3.56607$

$F^{3.44667}$

$\Gamma_{-2.55845}^{2.3849}$

.54614

2.44680
2.43715

2.42087
-2.41120

-2.41120
-2.25937
-2.25

$-2.24518$

$-2.12972$

1.93815
-1.92684

$-1.91887$

-1.90759

-1.89593

$-1.73843$

$\begin{array}{r}1.73843 \\ -1.71965 \\ -1.70953 \\ \hline\end{array}$

1.67529

1.61083

$-1.51455$

1.49170
-1.43874

-1.43874
-1.35730

1.45730
-1.34038

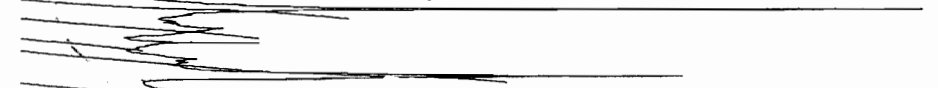

7.999

23.715

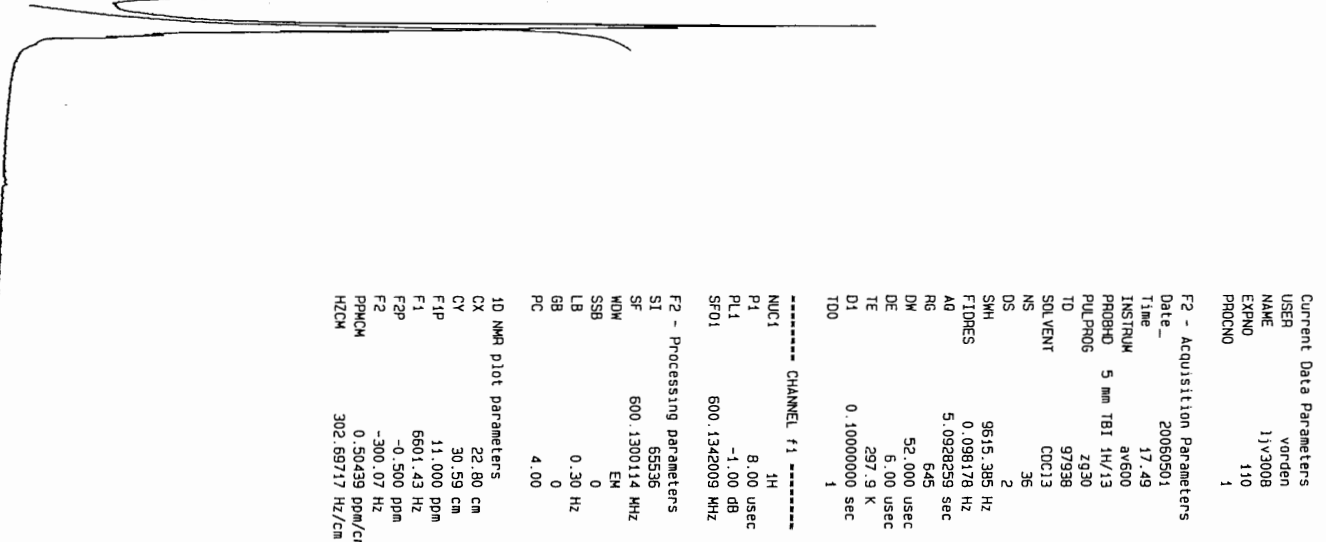

-1.27739
-1.27248

-1.26910
-1.26553

$-1.25369$

$-1.06431$

$-0.90063$

$-0.89133$

$\lcm{\square} \leftarrow 0.88332$

$-0.87369$

$\square 0.86248$

$-0.84454$

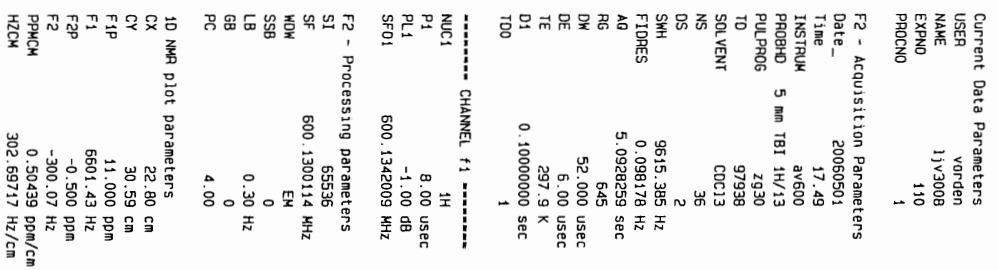




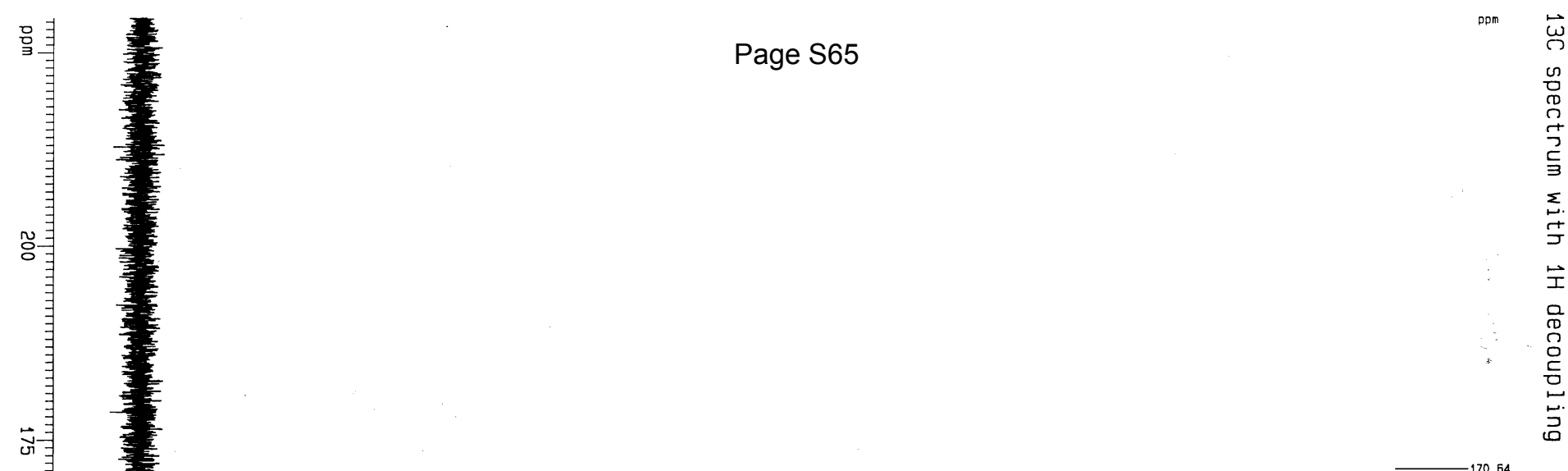<smiles>CO[C@@H](/C=C/CC(C)C)C[C@@H]1CC[C@@H](C)C(C[C@@H](C[C@@H]2C[C@@H](O)C[C@H](CC(=O)O)O2)OC#N)O1</smiles> 


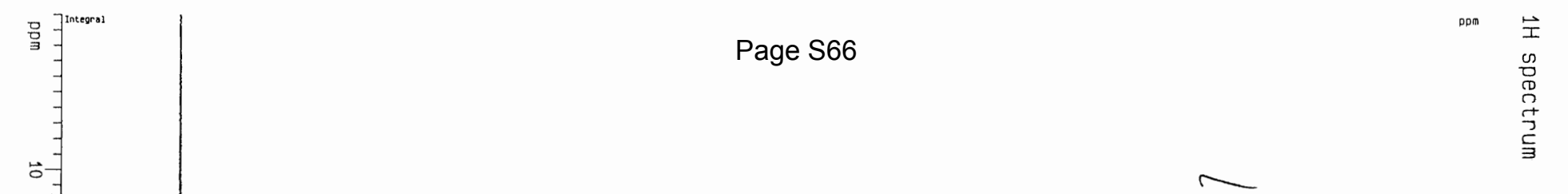




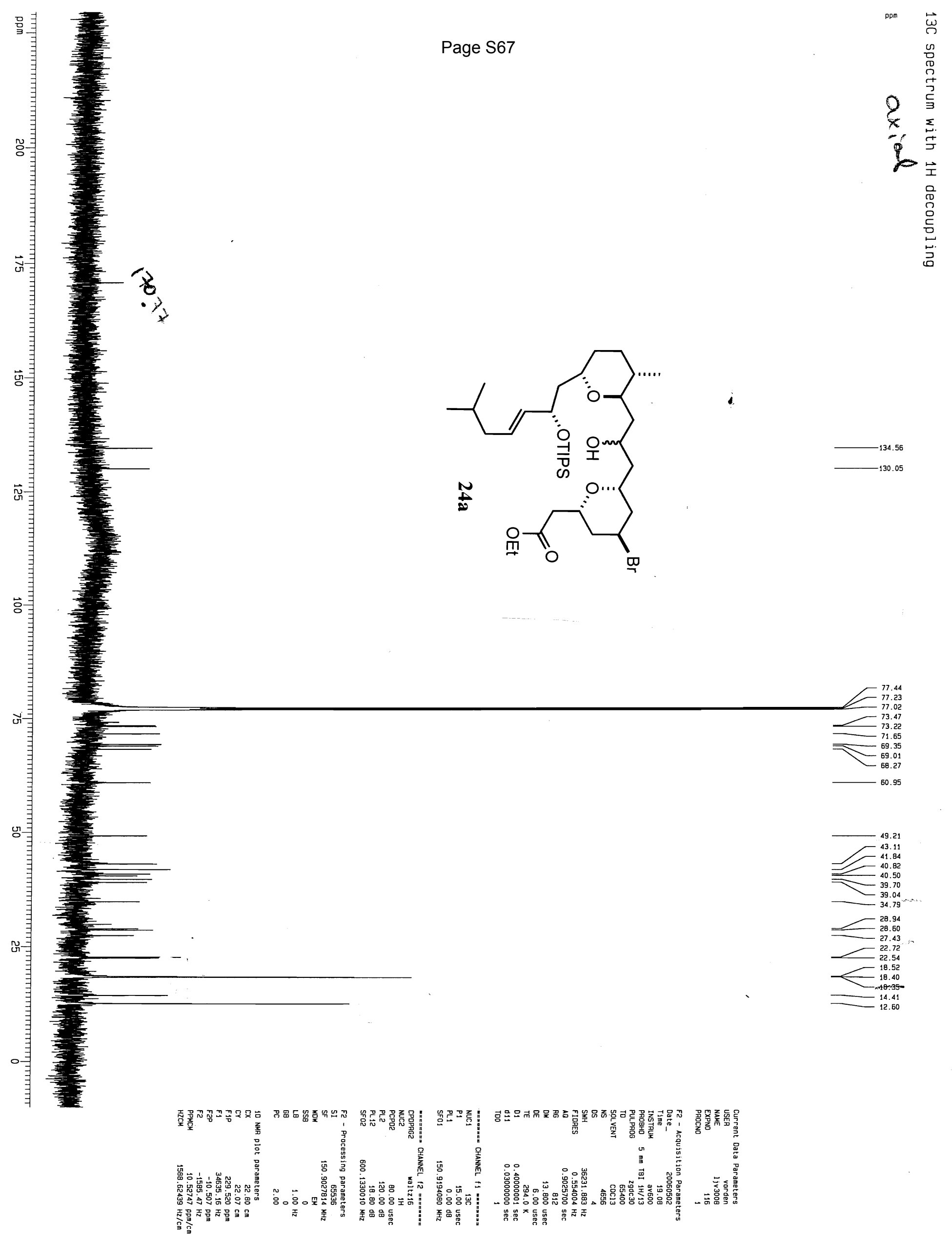




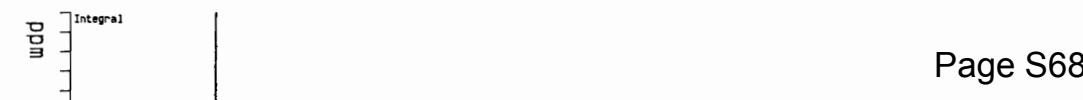
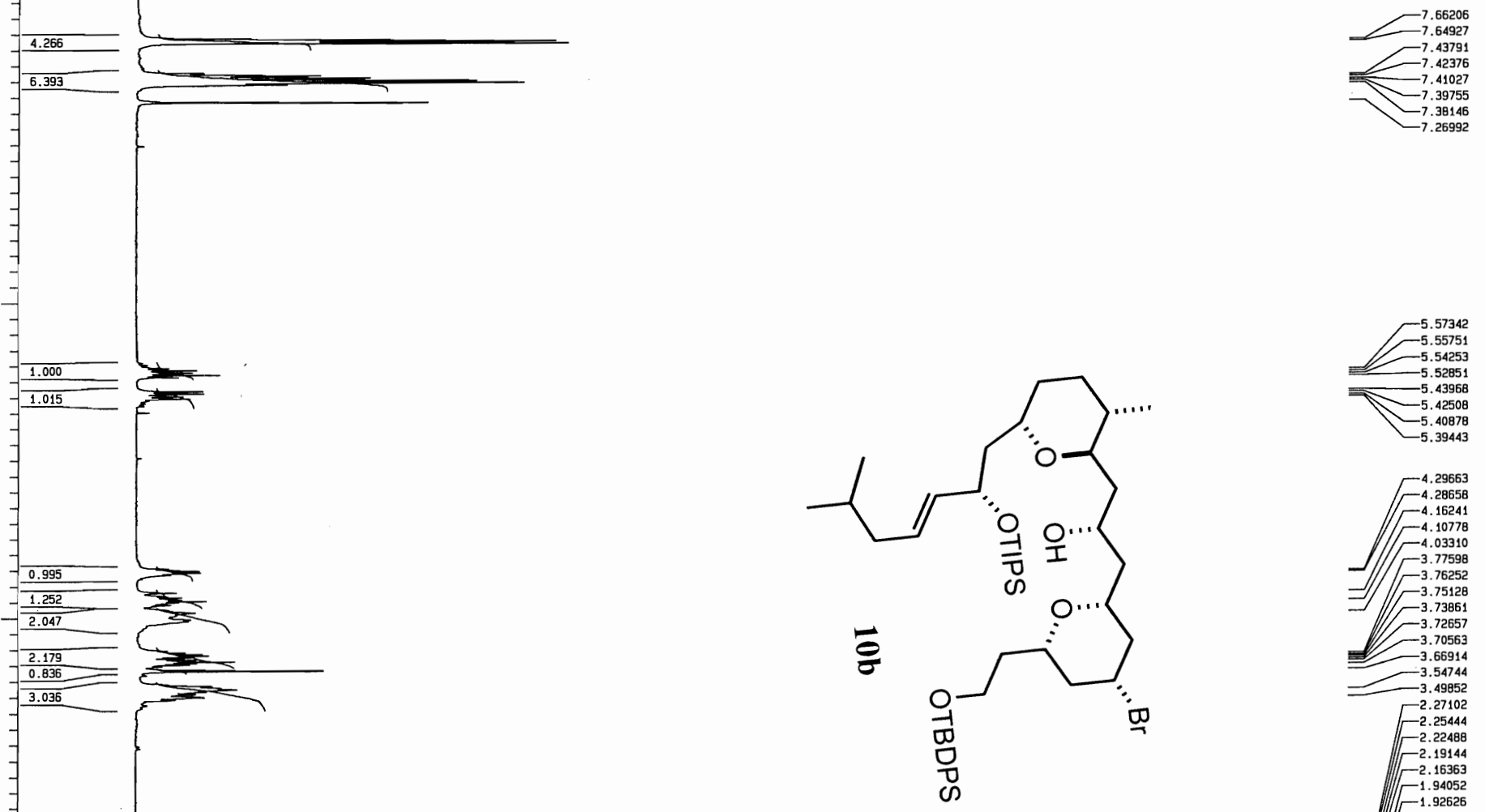

3.49952

-2.27102

-2.25444
-2.22488

$\begin{array}{r}2.22488 \\ -2.19144 \\ \hline\end{array}$

-2.16363
-1.94052

作-1.94052

$-1.90866$

$-1.89454$

$\Gamma^{-1.83864}$

$+1.82368$
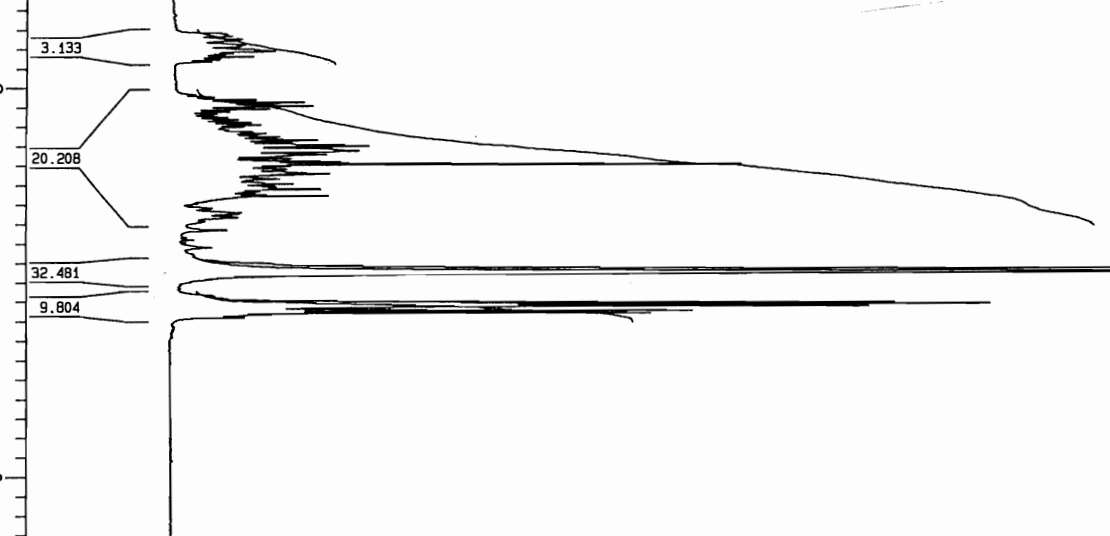

$-1$
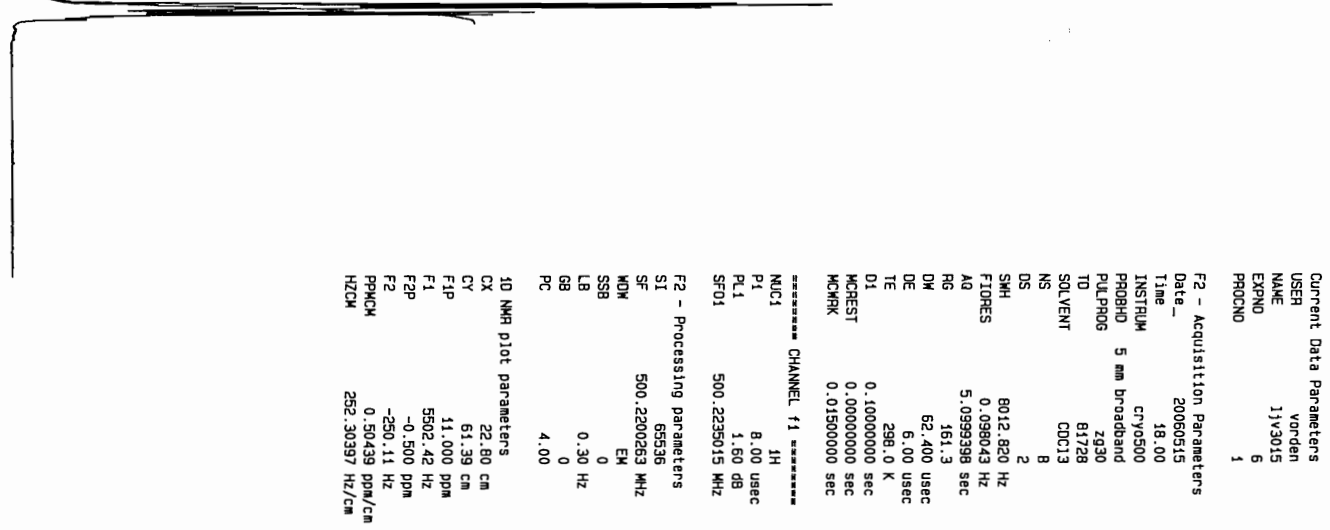

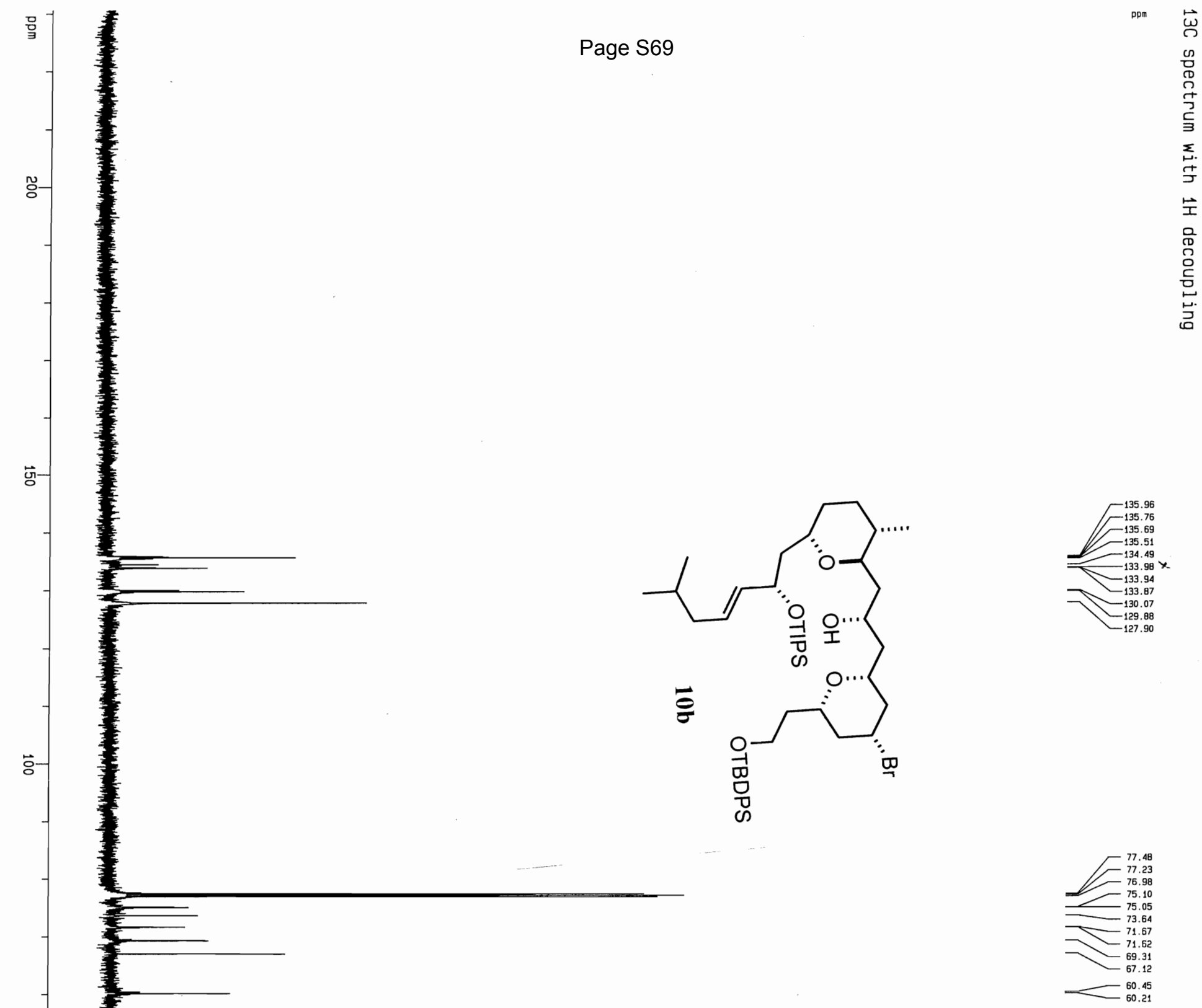

G
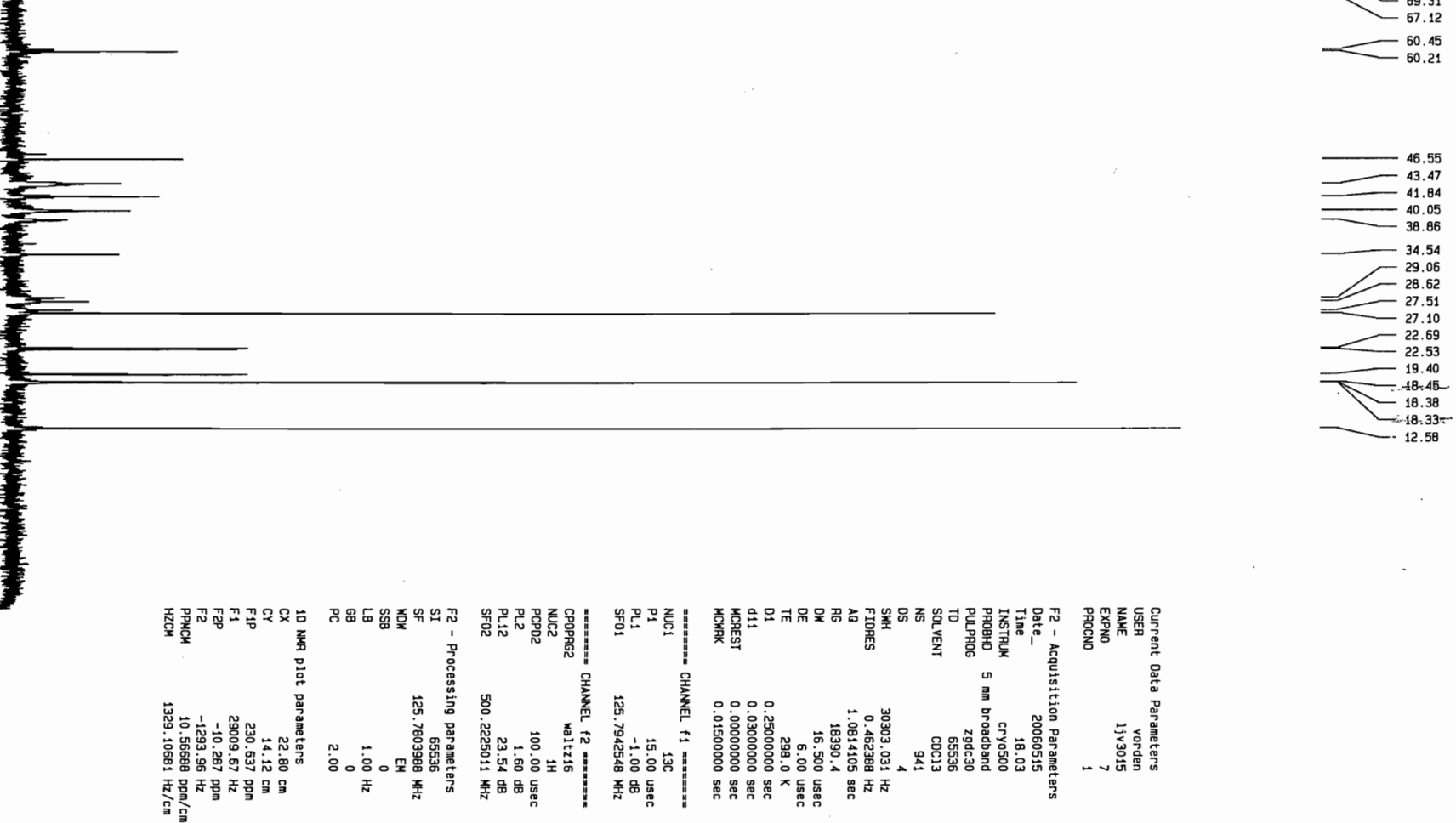


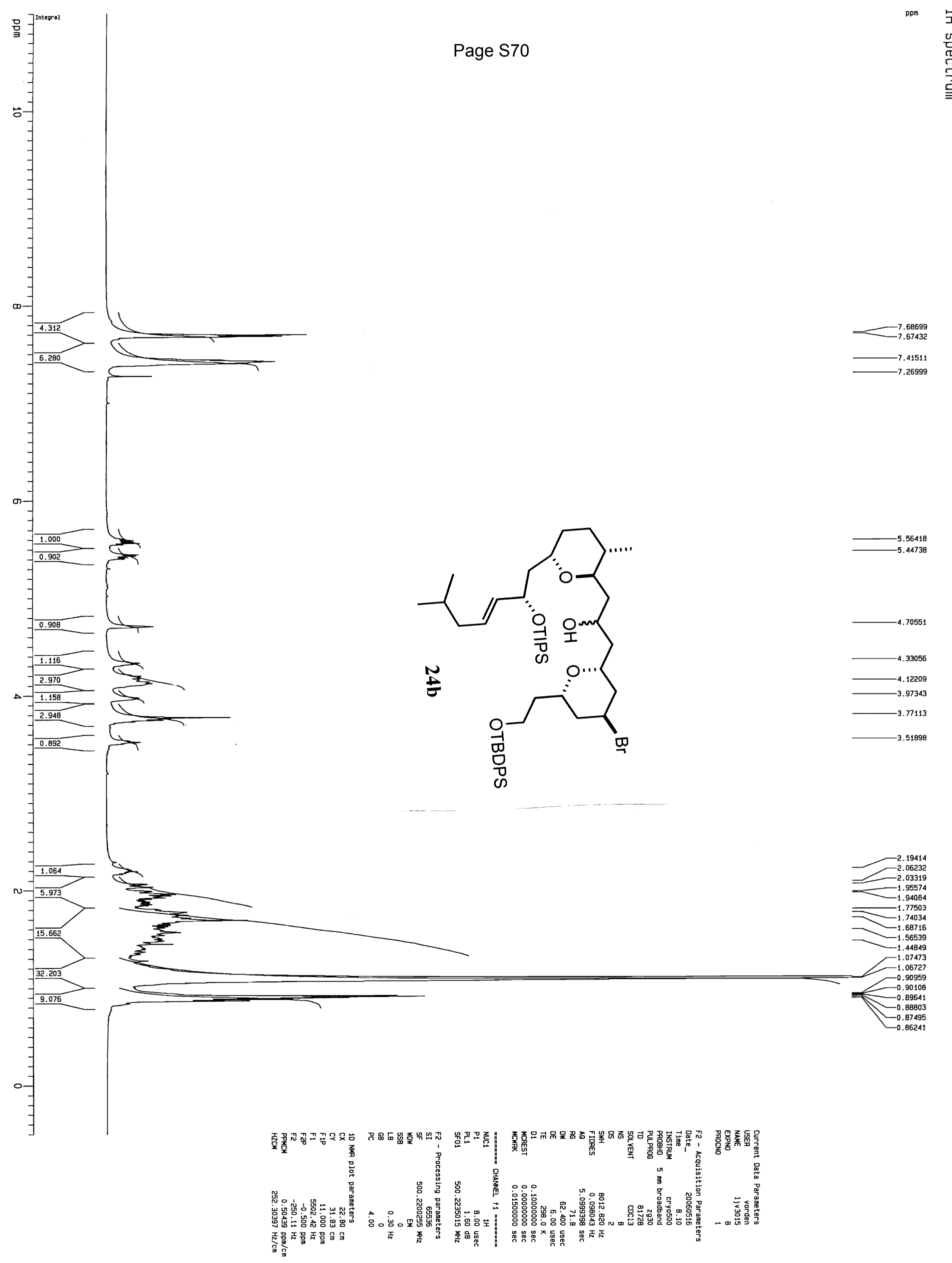




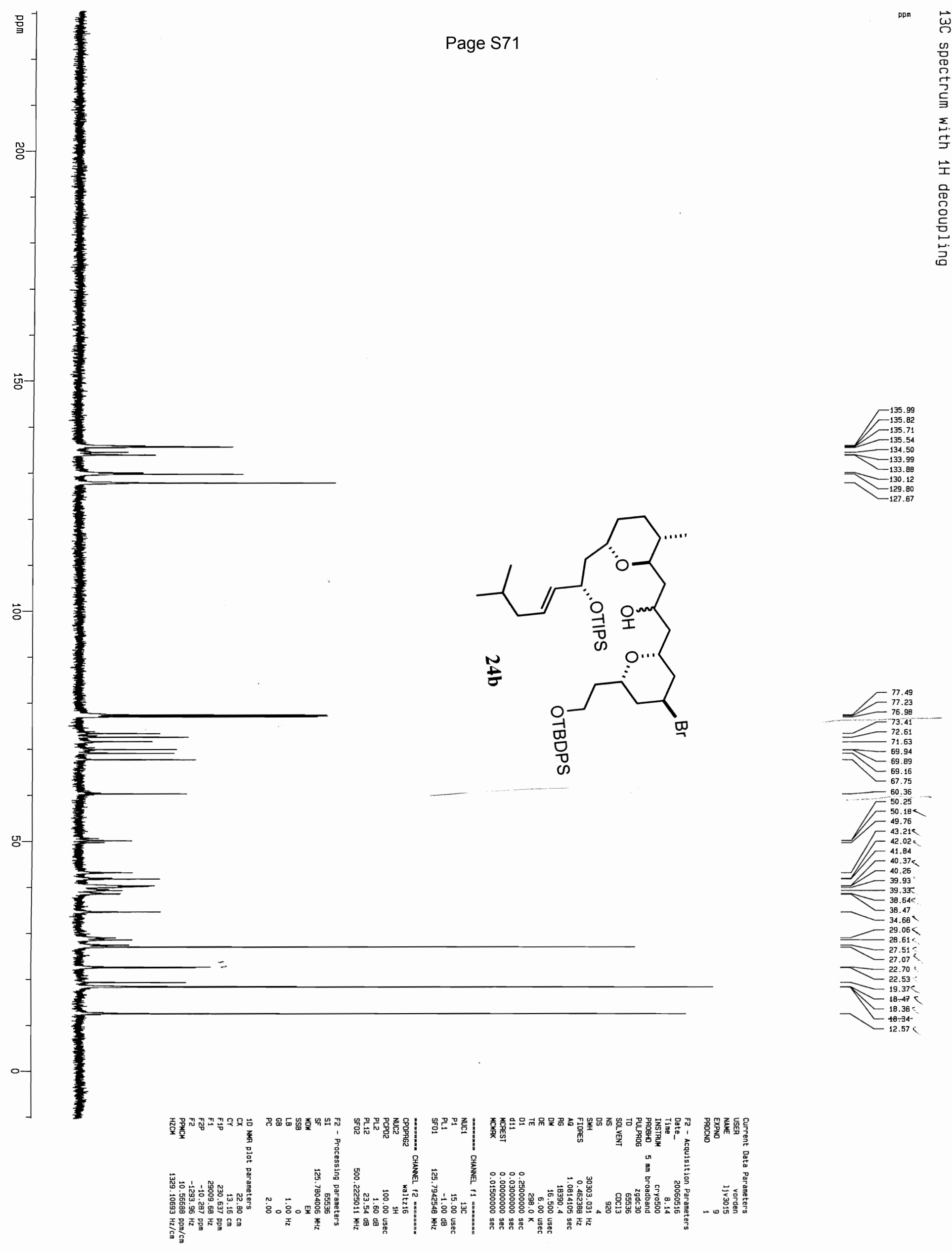




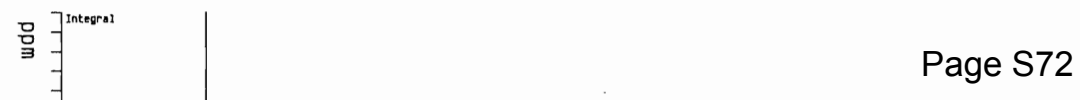
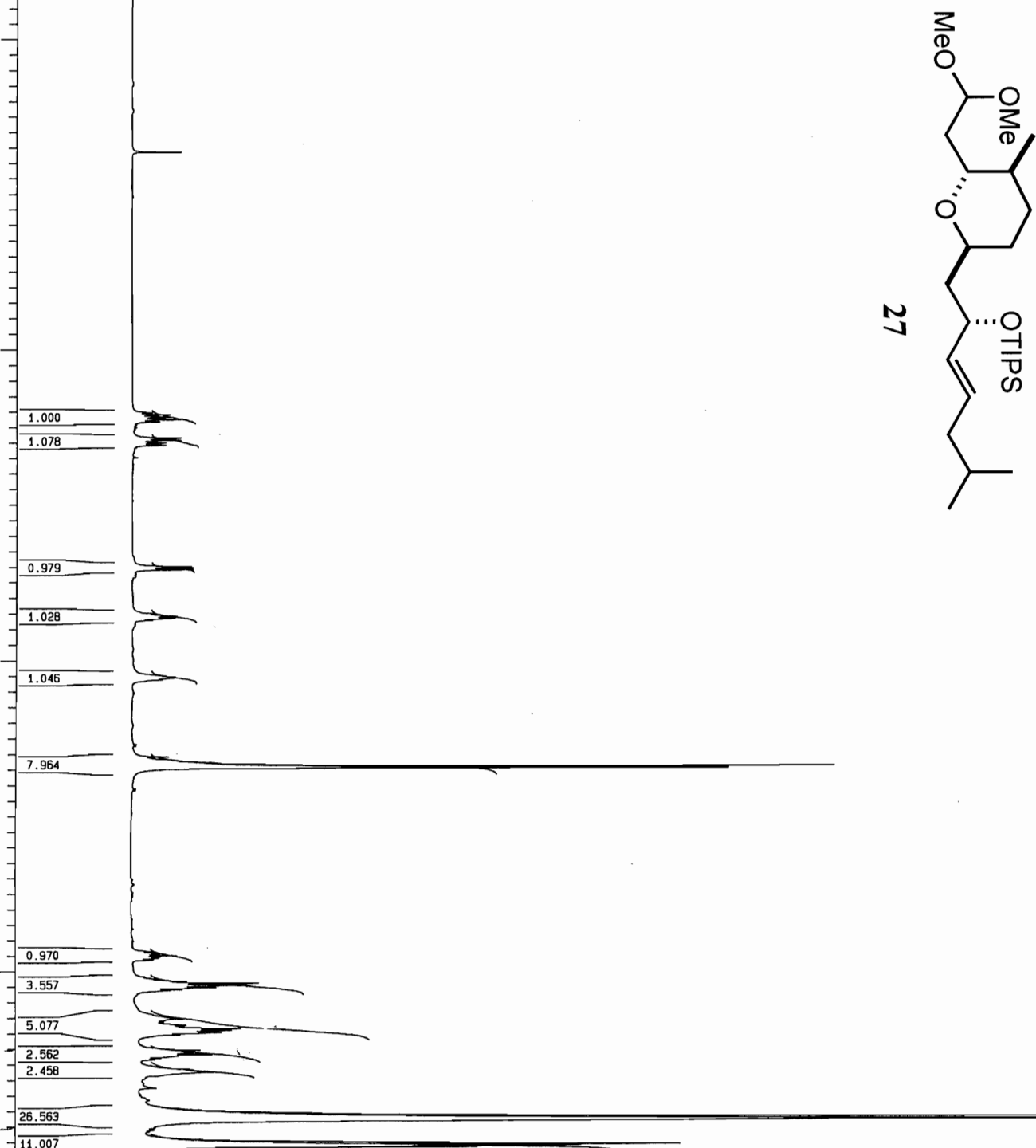$$
\text { 。 }
$$
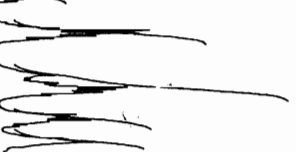

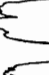
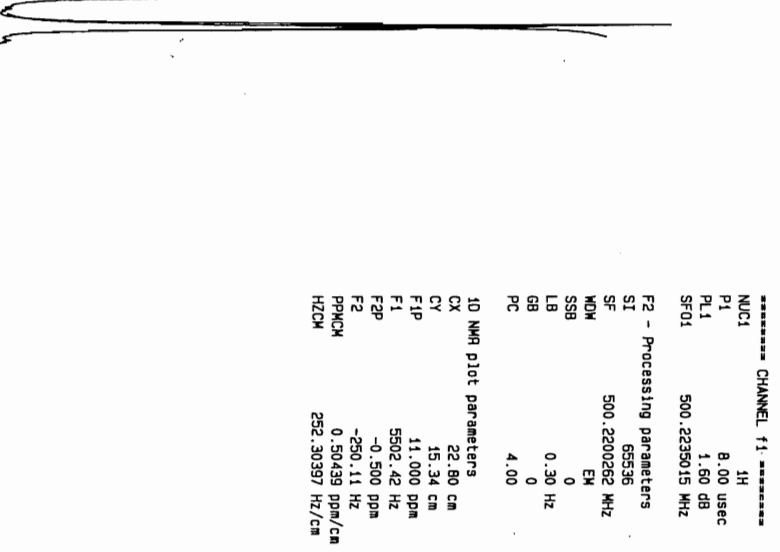


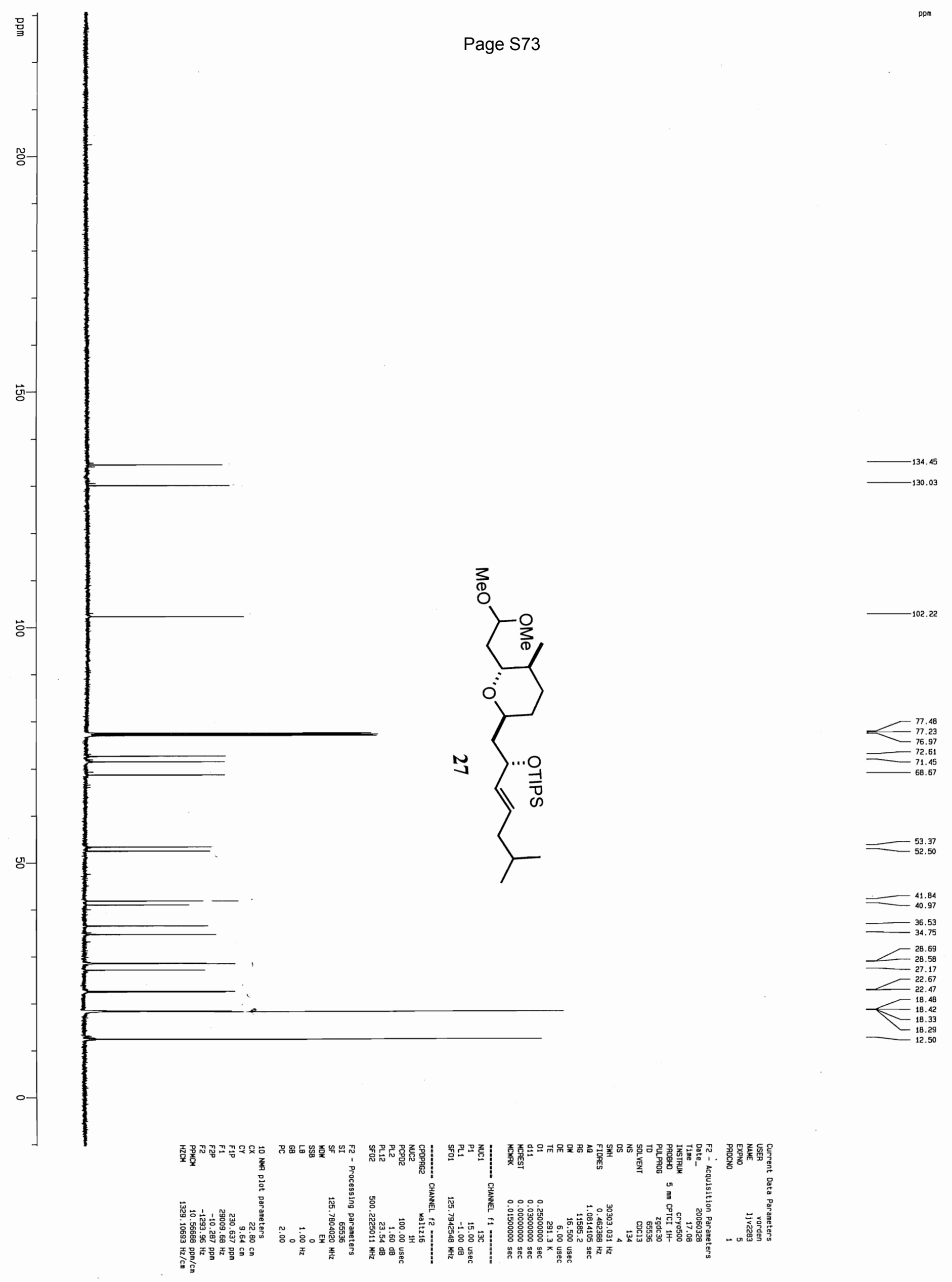




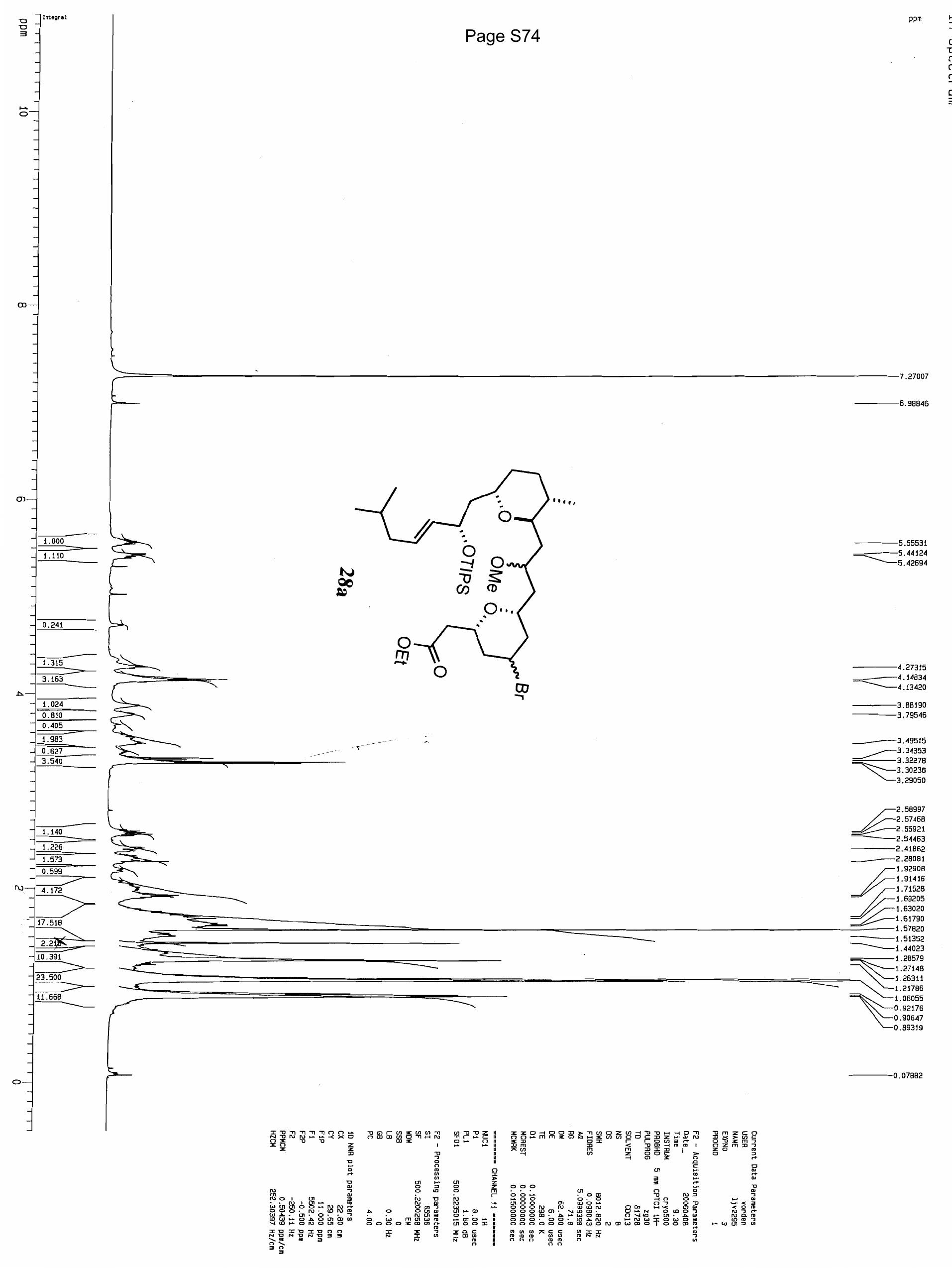




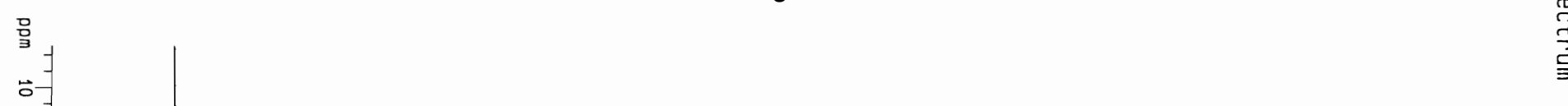

Page S75

.

$\infty$
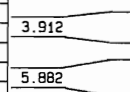

-
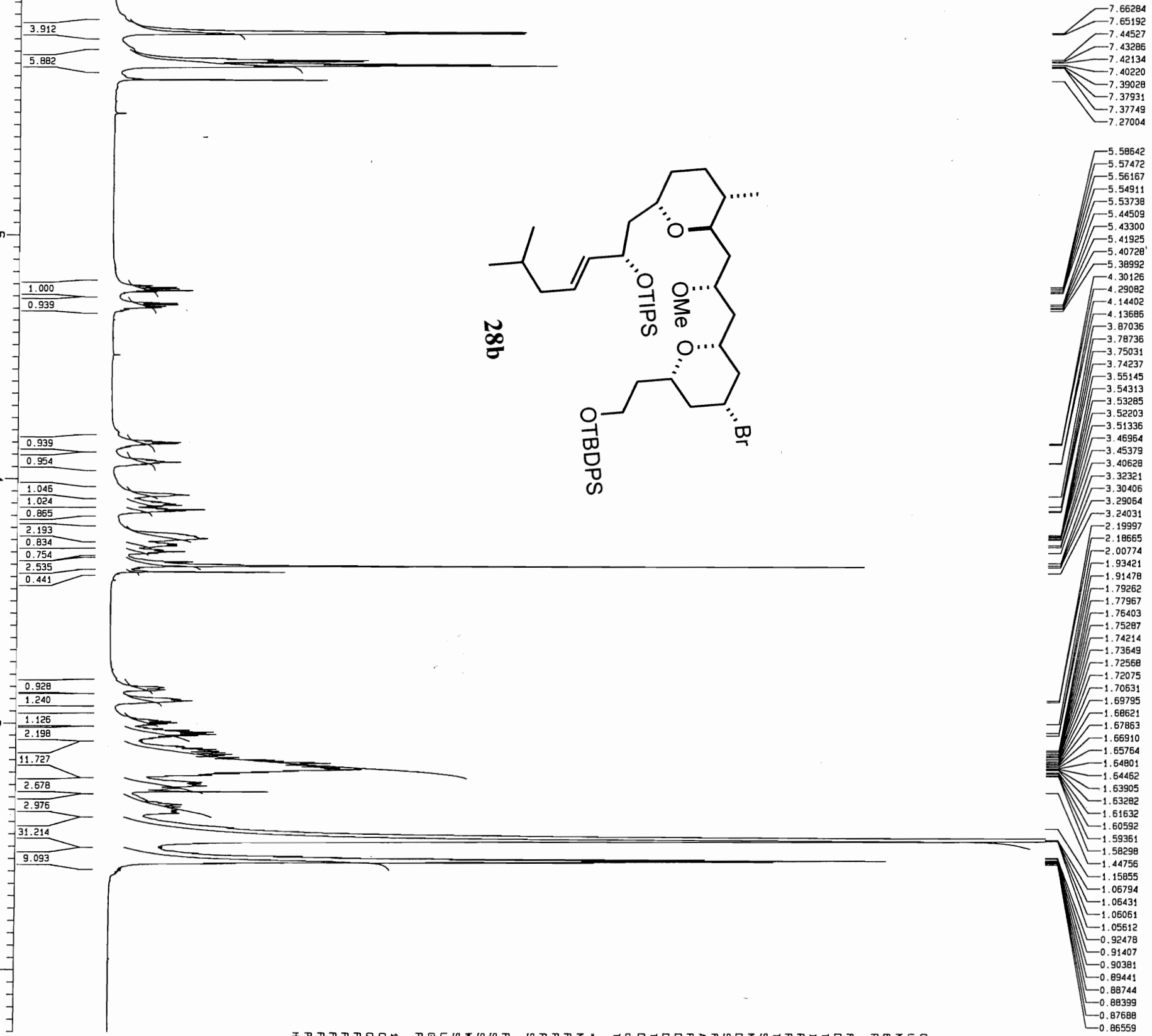

-4.13686

$F^{3.87036}$

$\begin{array}{r}3.75031 \\ -3.74237 \\ \hline\end{array}$

- 3.55145

$-3.54313$

$-3.52203$

- 3.51336

- 3.45379

-3.32321

- 3.30406

-3.24031

$F^{-2.19997}$

$F_{-1.93421}^{2.0077}$

$F^{1.93421}$

-1.91478
-1.79262
-1.77967

-1.77967
-1.76403

$F_{-1.75287}^{-1.76403}$

-1.74214
-1.73649

-1.73649
-1.72568

${ }_{-1.68621}^{-1.69795}$

1.6786

$-1.66910$

1.65764

$-1.64462$
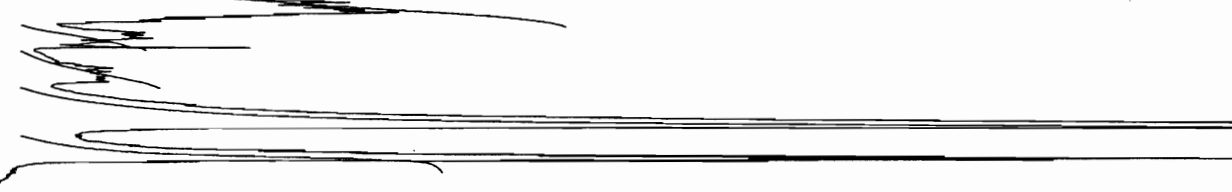

7) -1.59361

$\square_{-1.58298}$

-1.44756
-1.15855

$-1.06794$

$-1.06431$

$\leftarrow 1.05612$

$\square 0.92478$

$-0.91407$

$-0.90381$

-0.89441
-0.88744

-0.88744
-0.88399

0.88399
-0.87688
-0.85559

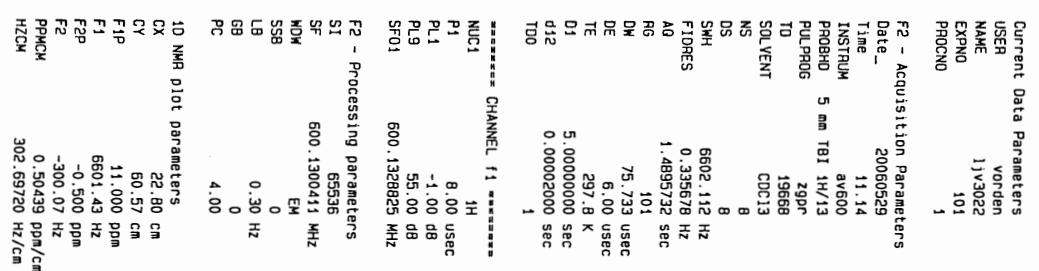



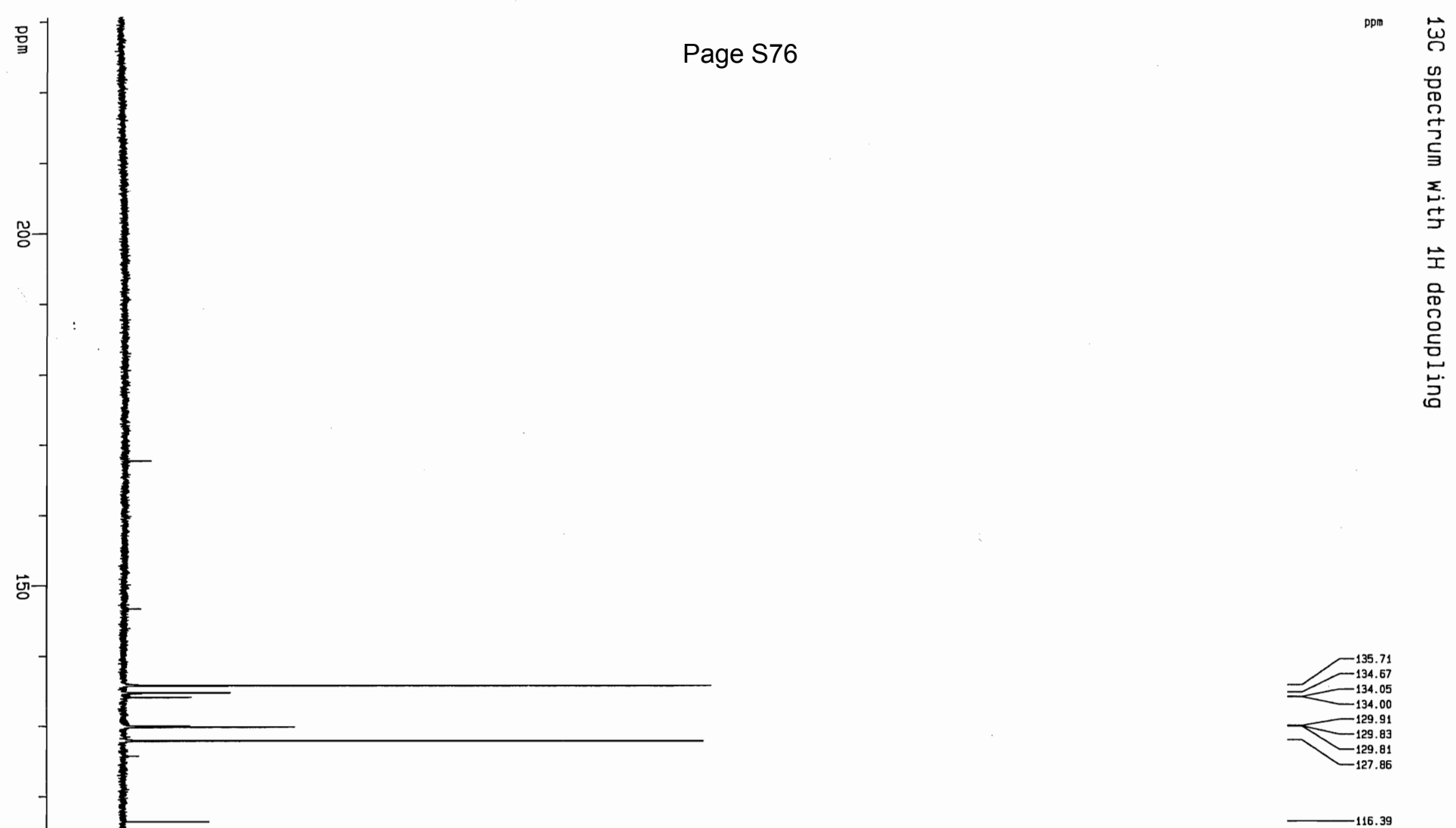

ㅂ̆ㅇ
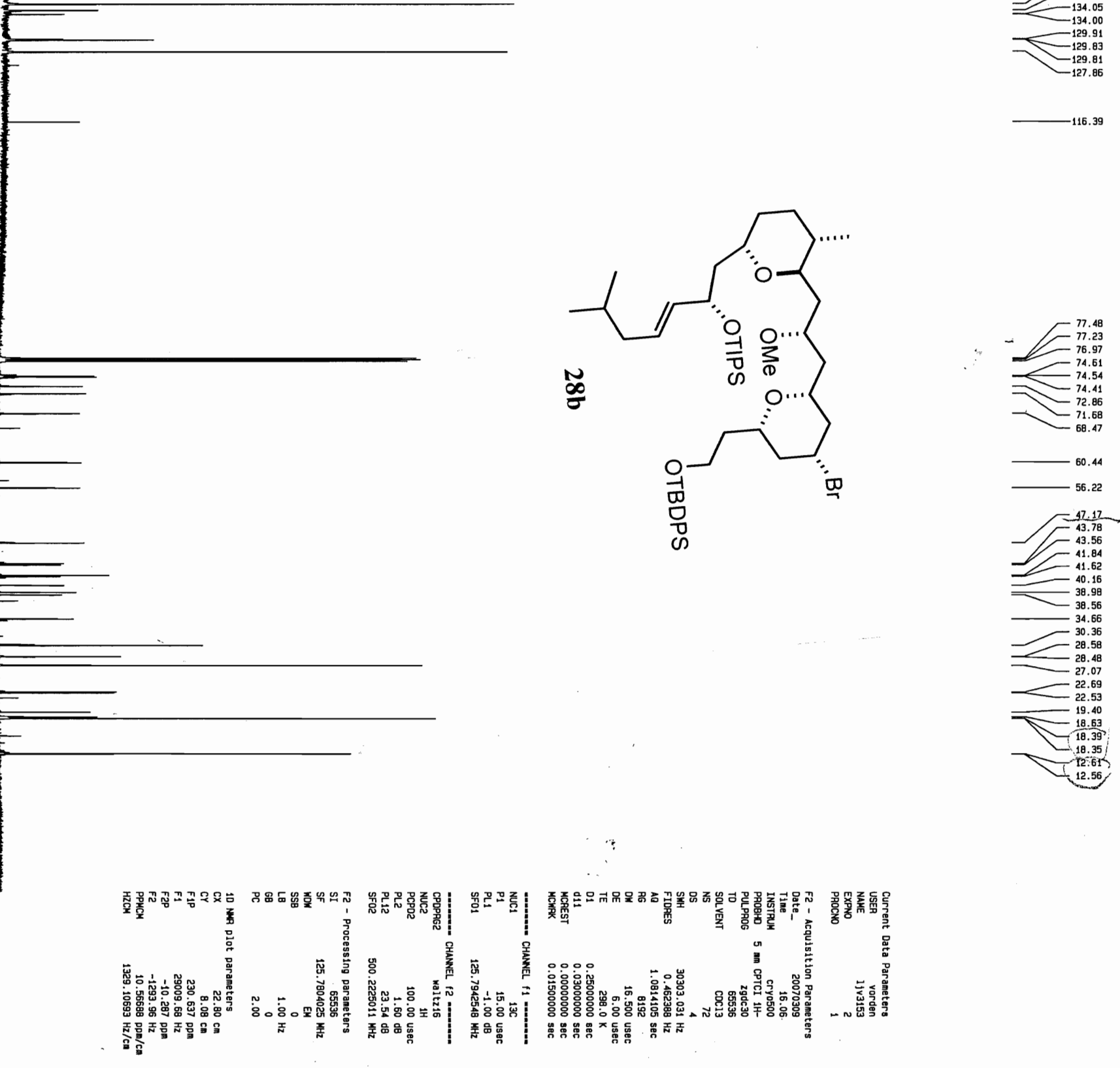


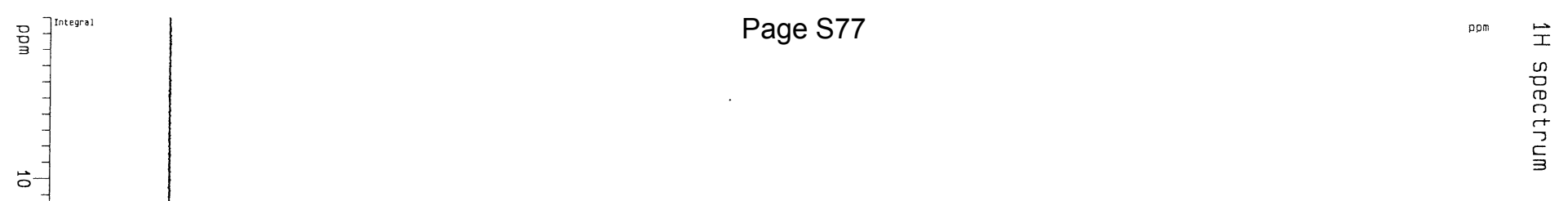



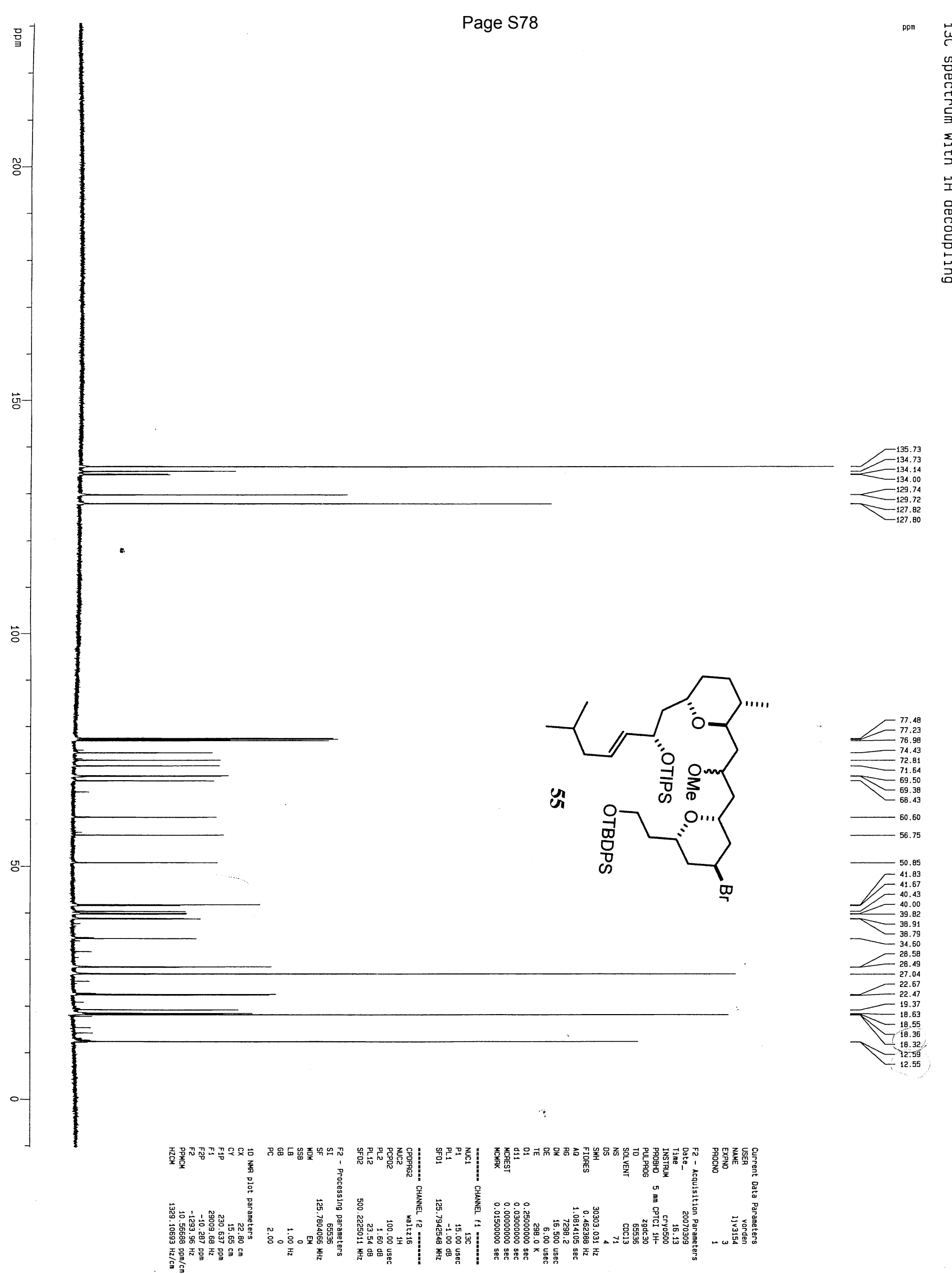


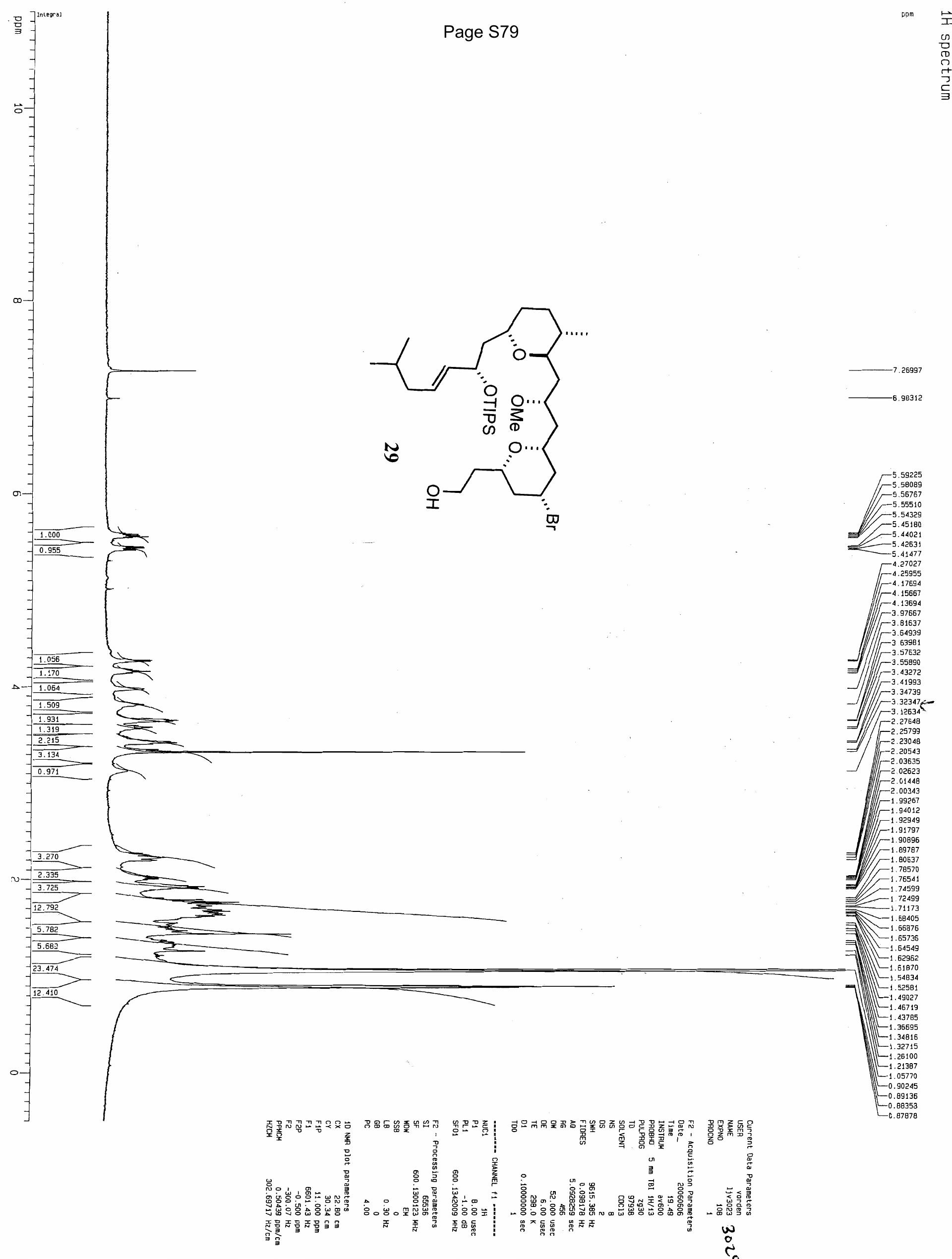




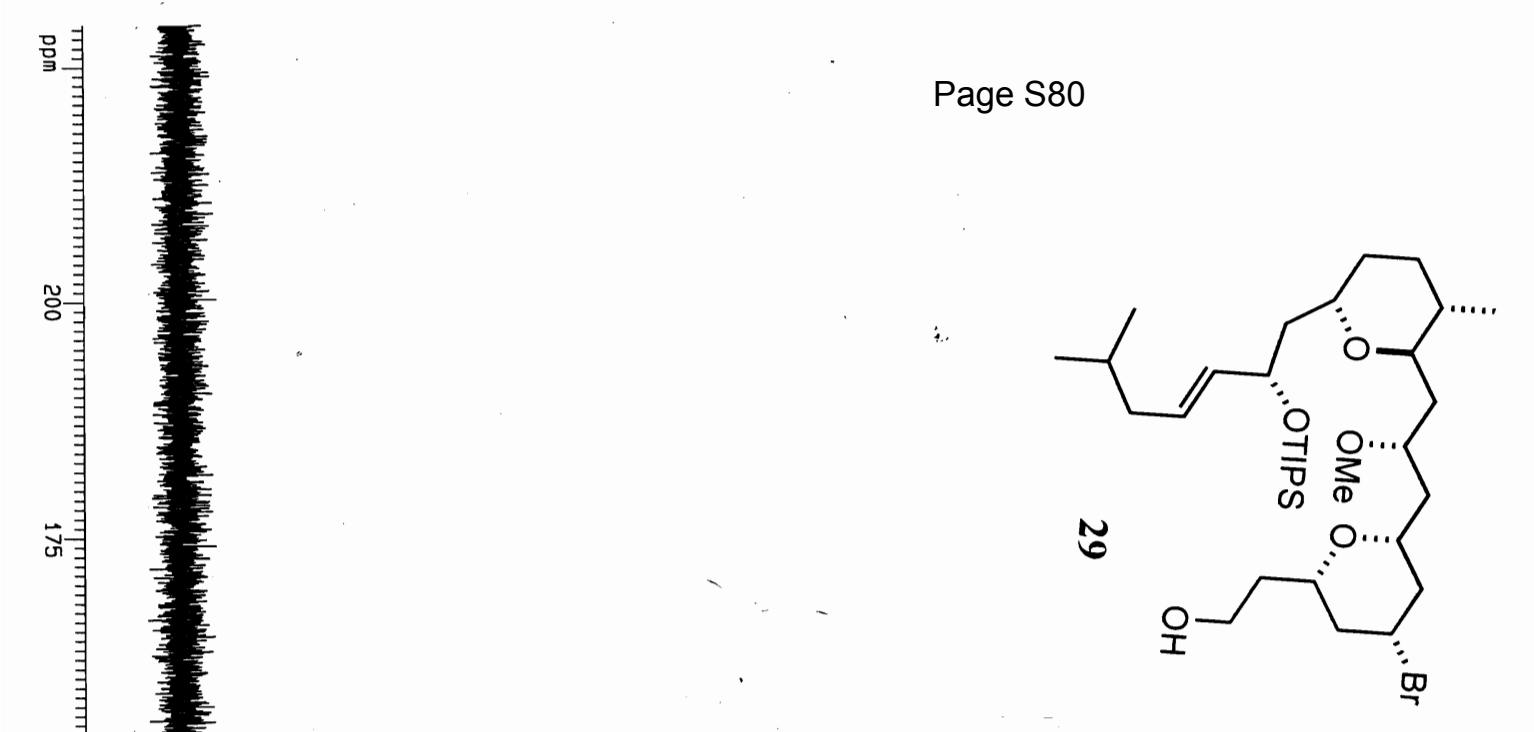

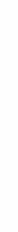
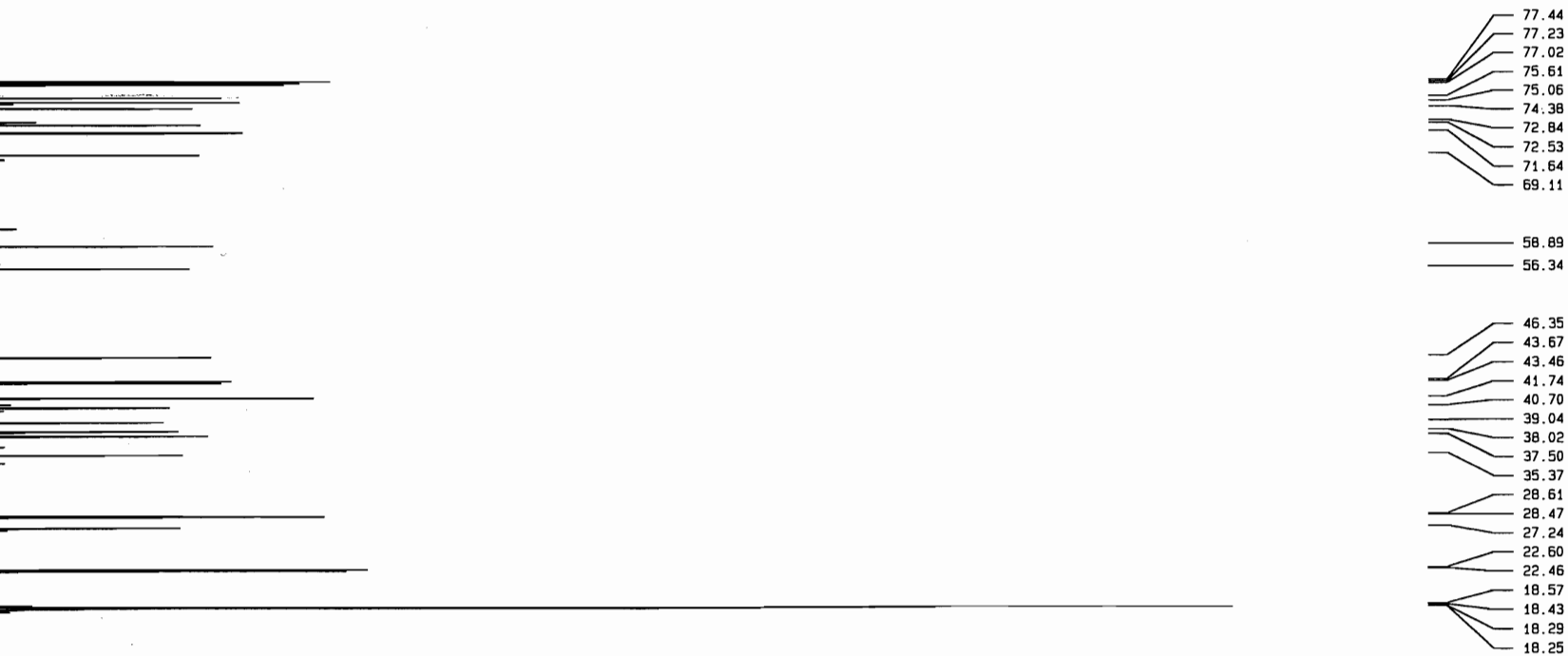


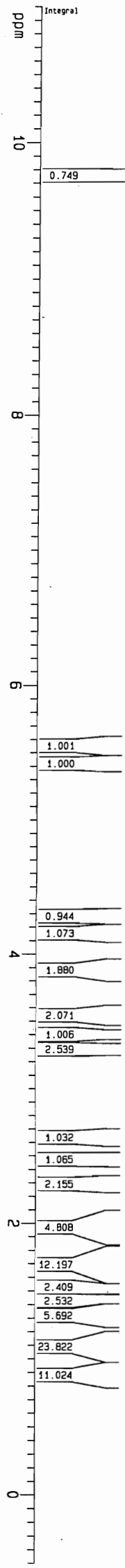

Page S81
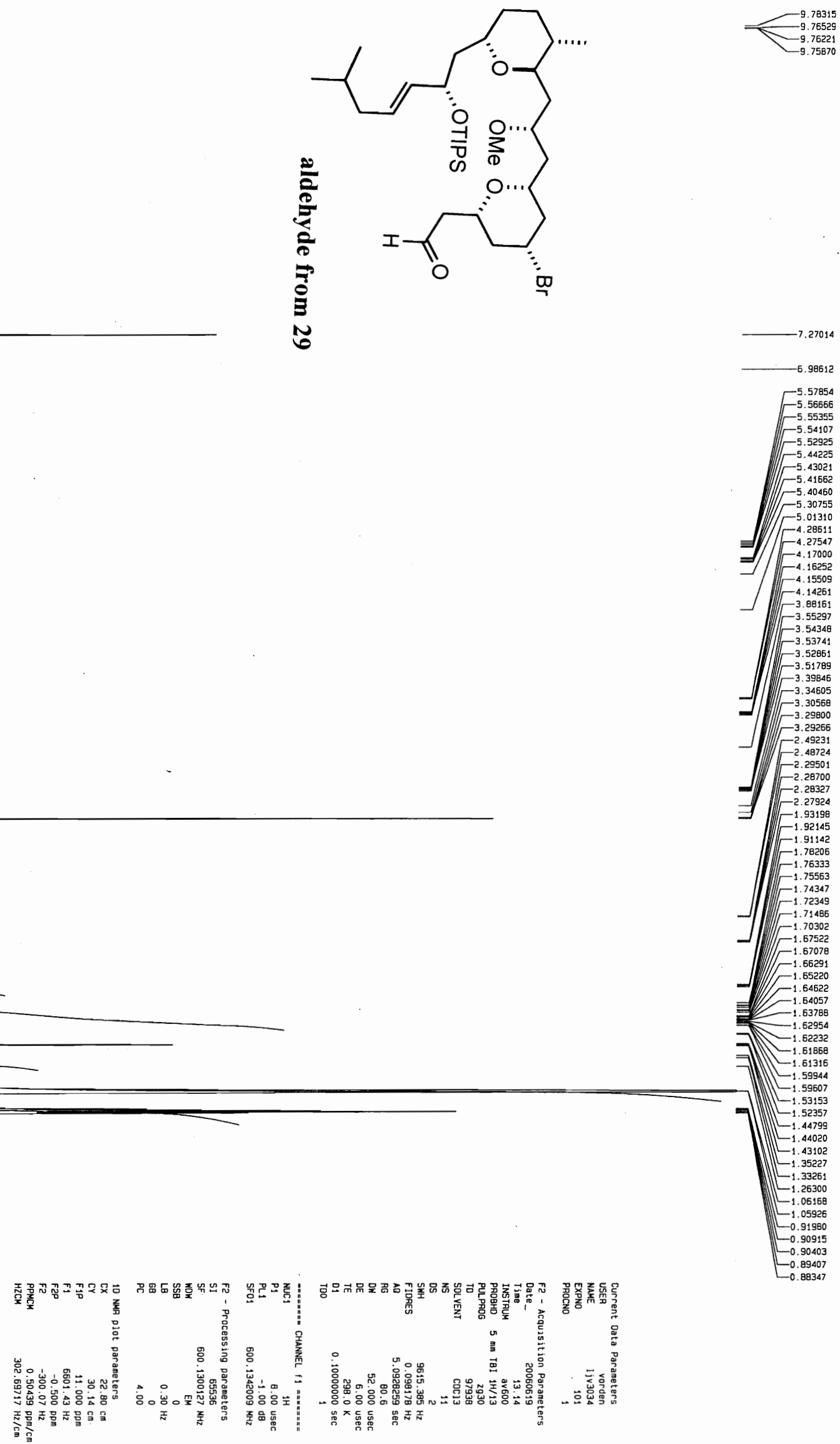


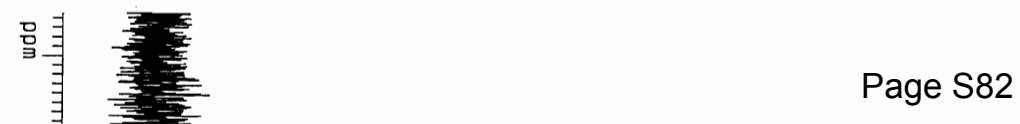

옹

जै

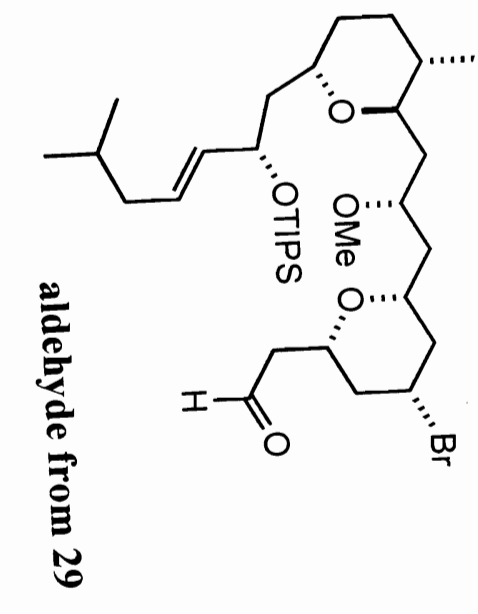

200.34

岕录

방ㅋㅋㄱ

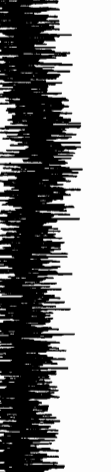

जั
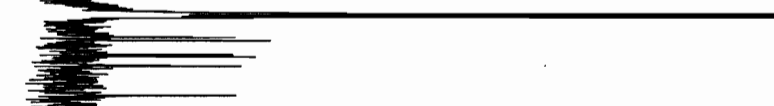

$-134.73$ $-129.87$

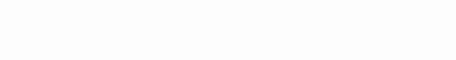




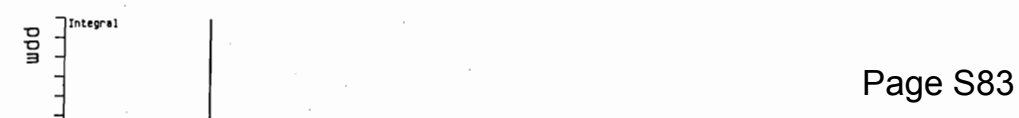

○
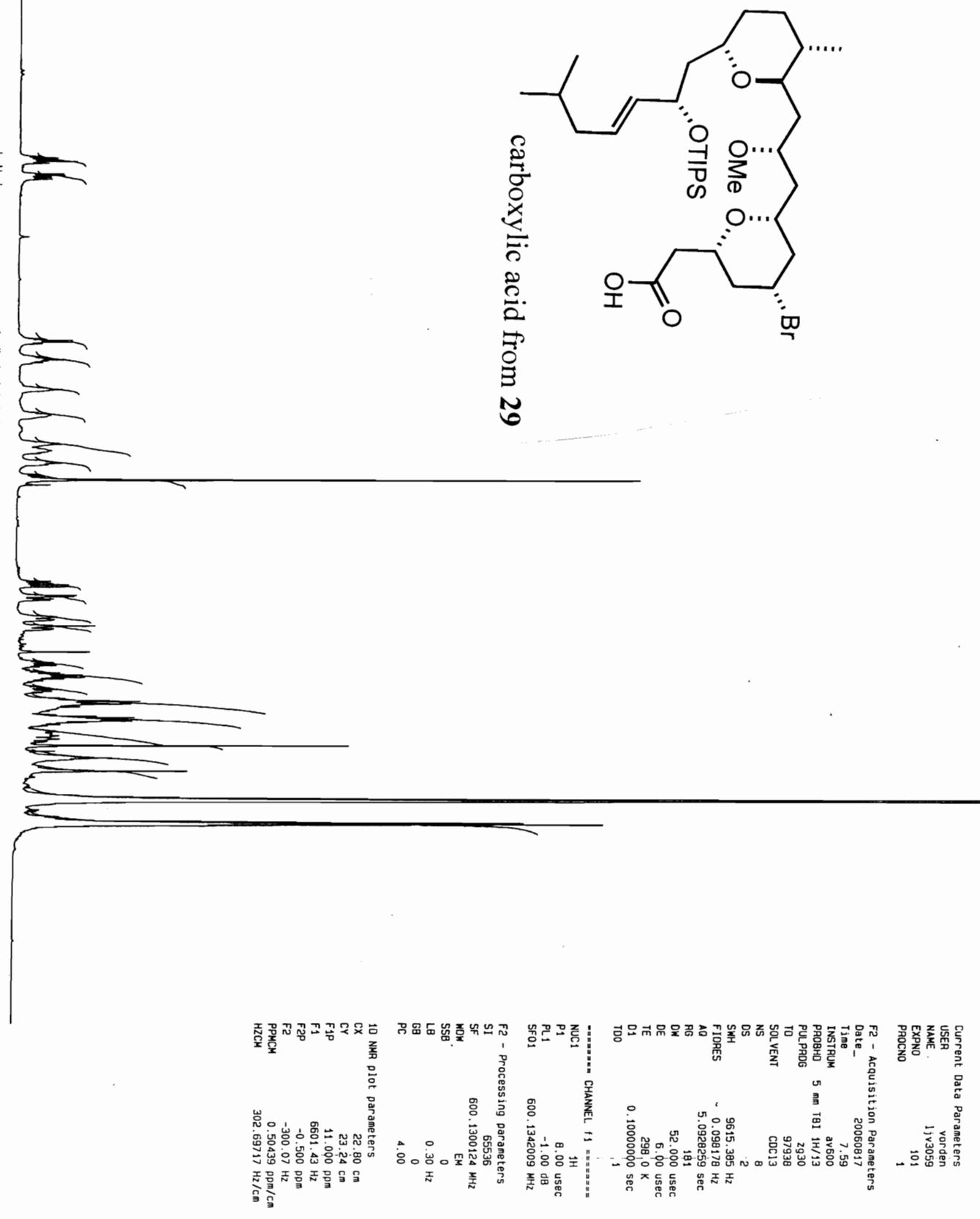

$$
\text { n }
$$
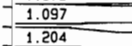

$-\frac{1.063}{2.294}$

$-\frac{1.148}{4.846}$

$-4.846$

$-4.332$

2.843

$-\frac{2.843}{2.611}$

$-21.898$

10.500 

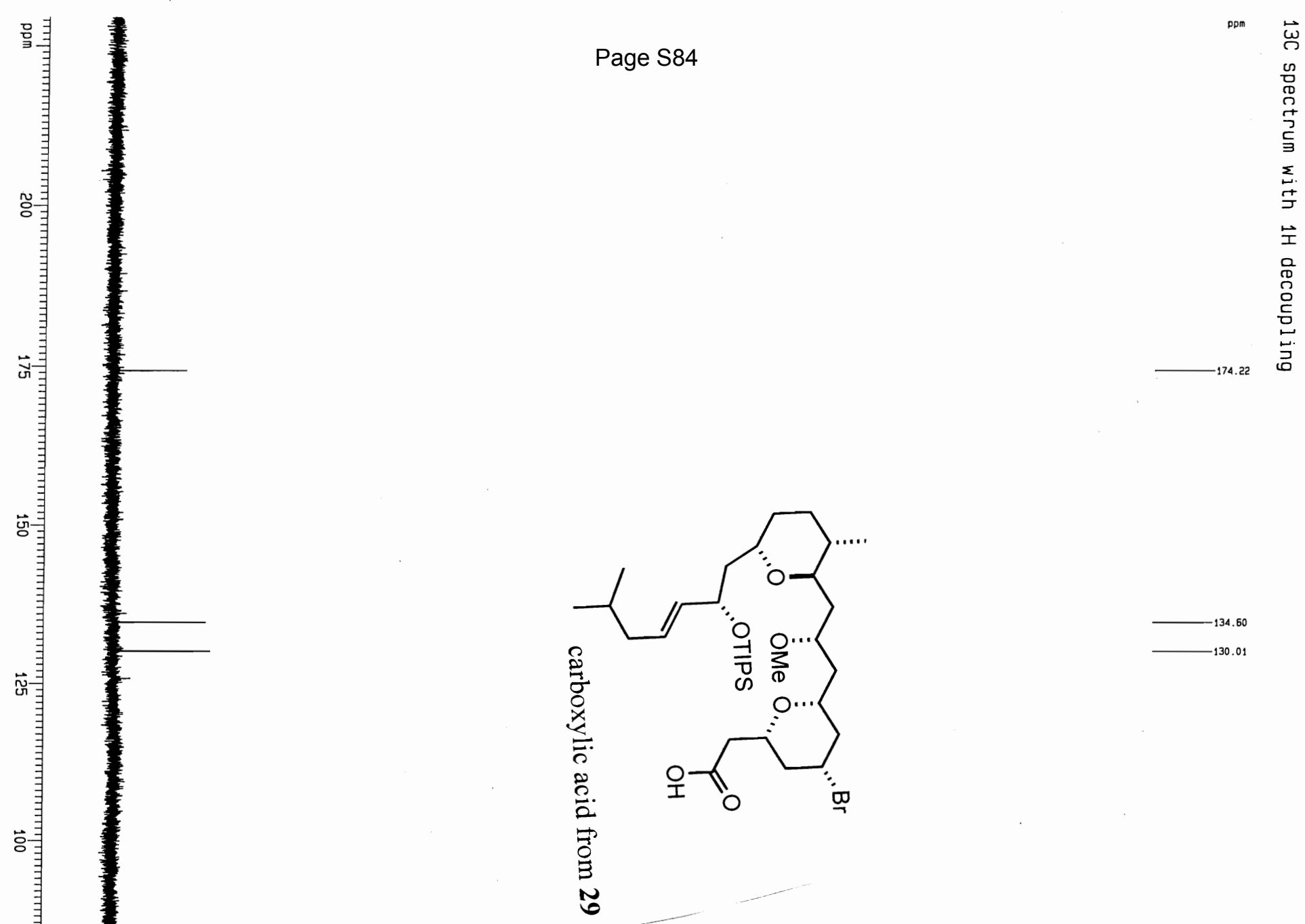

氜

흥

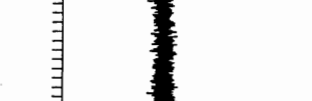

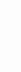

睊

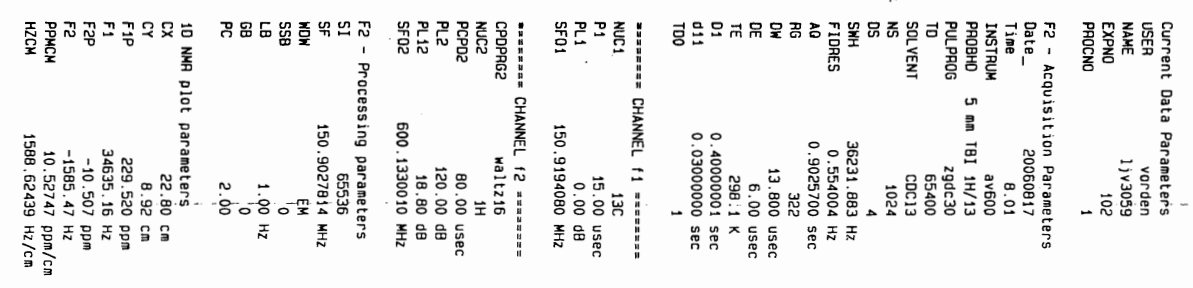




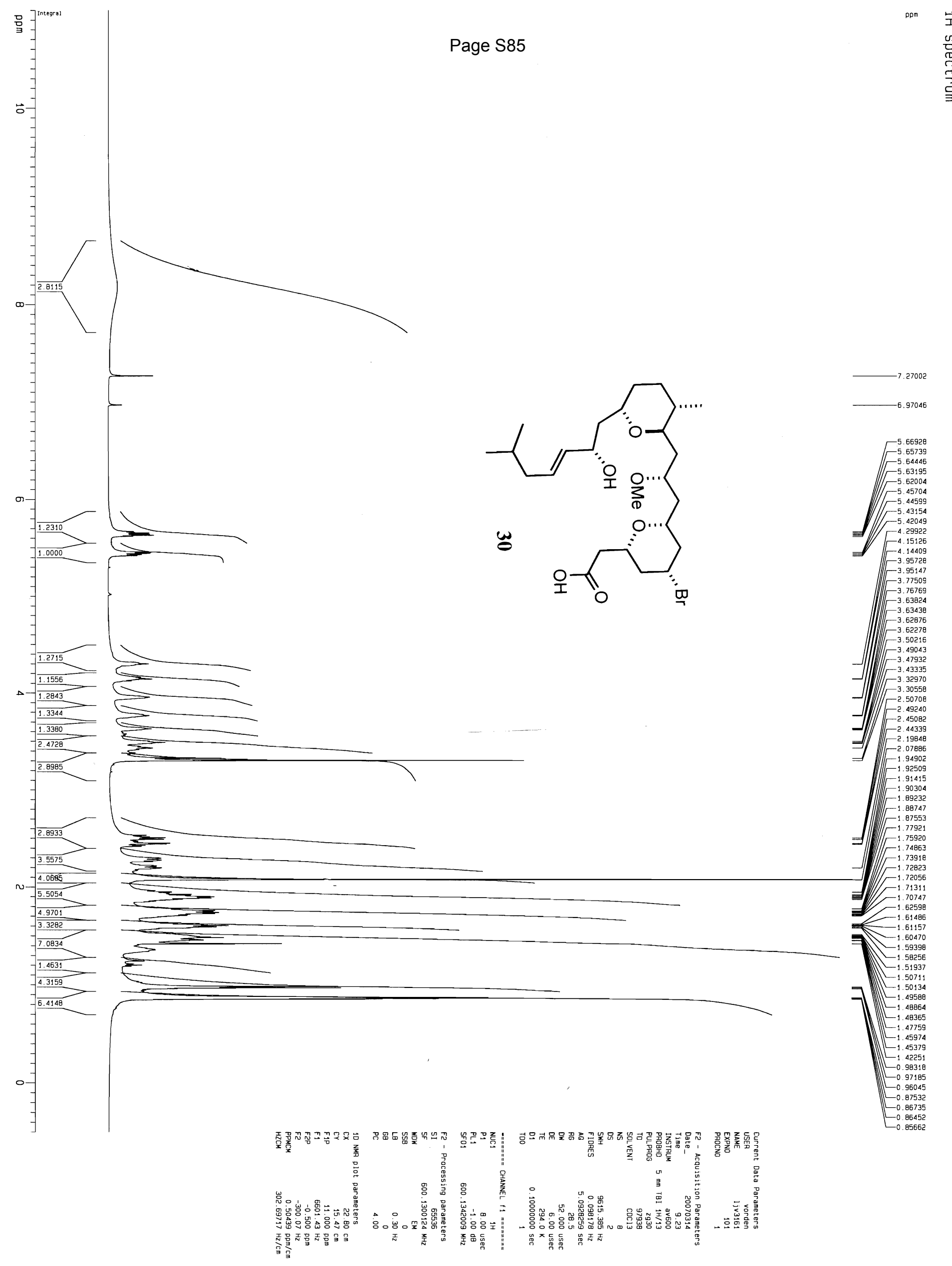



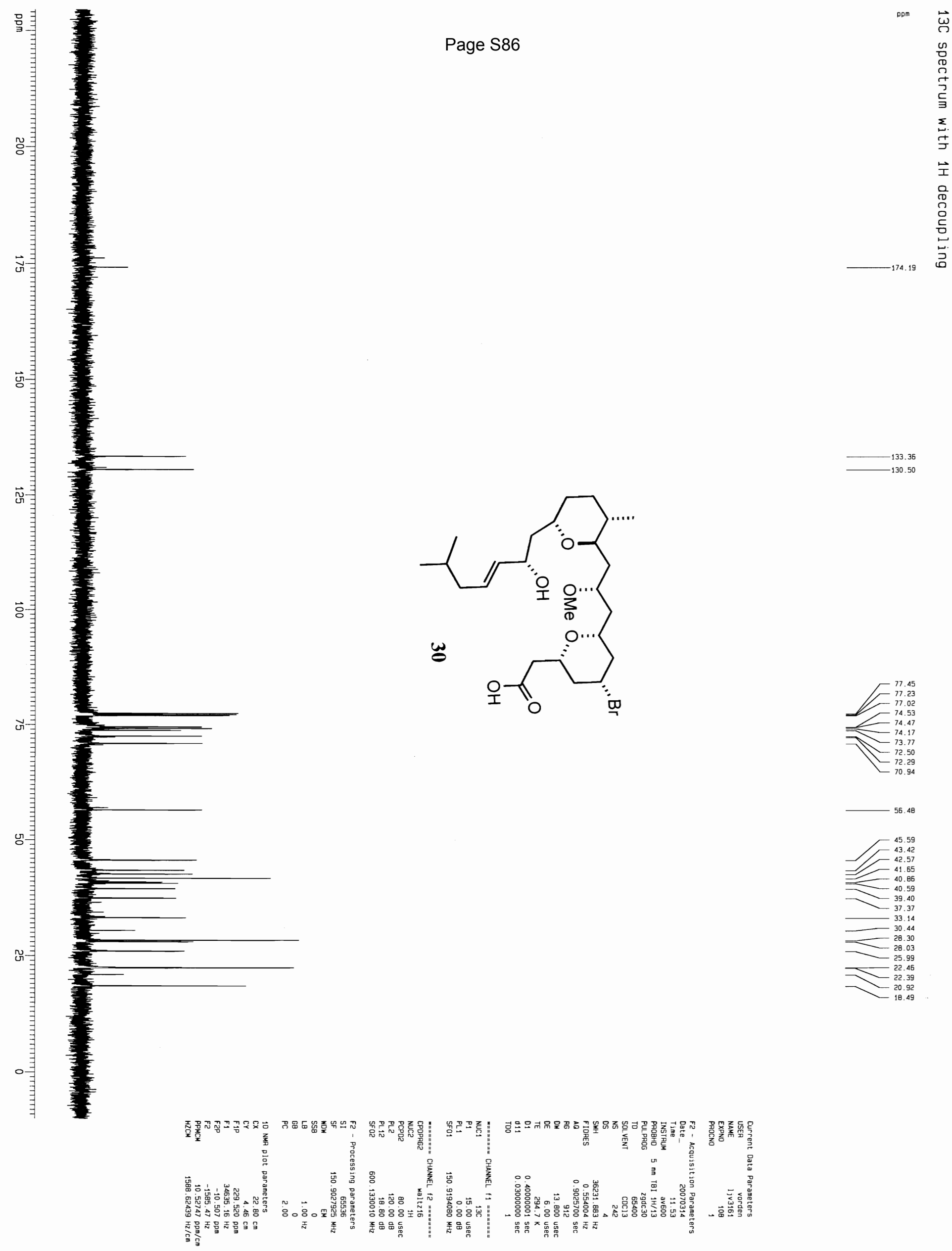


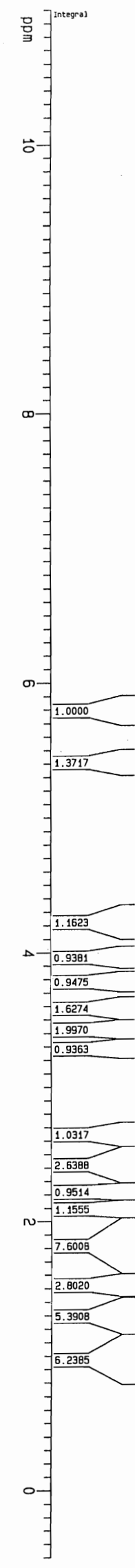

Page S87
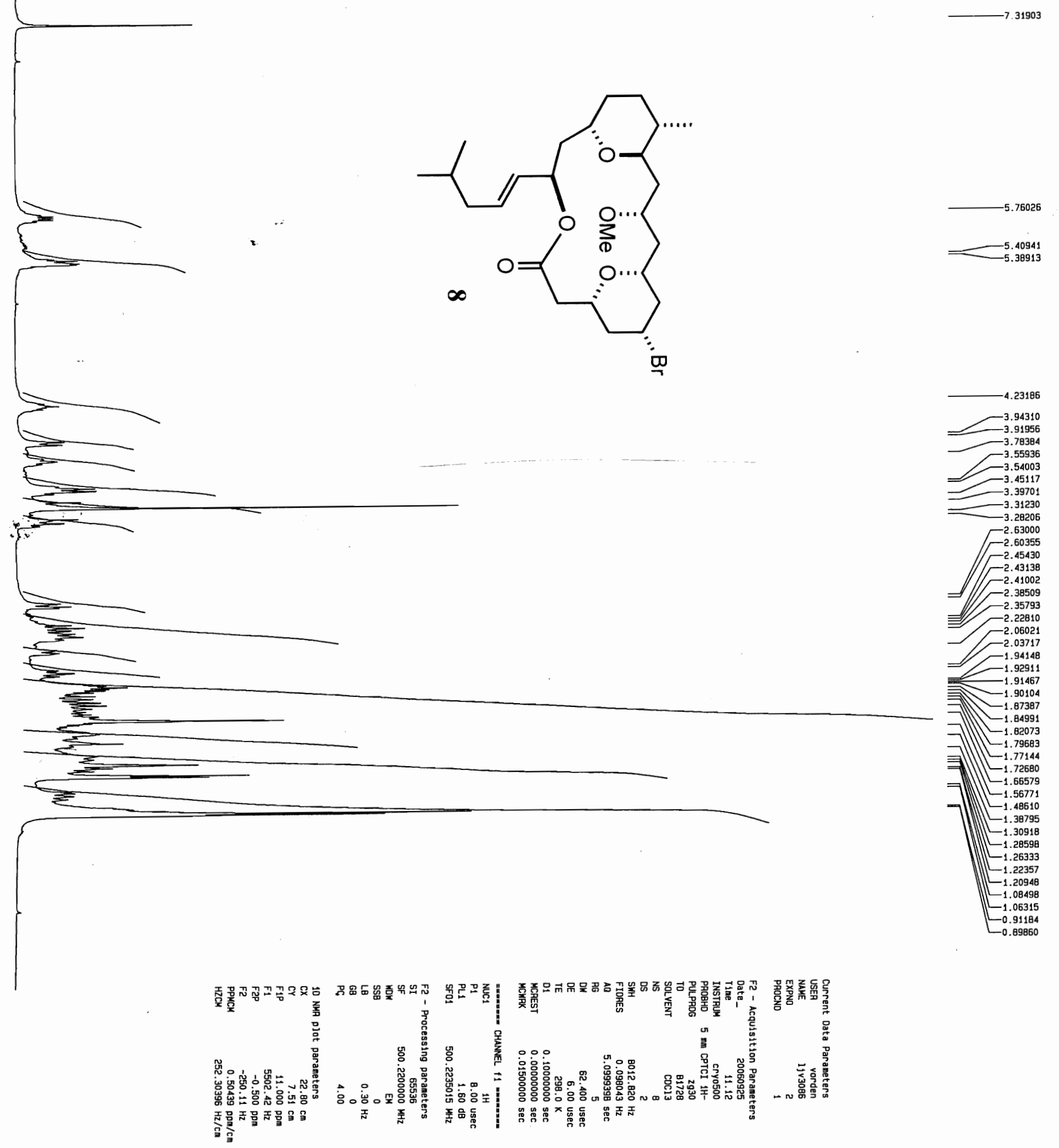


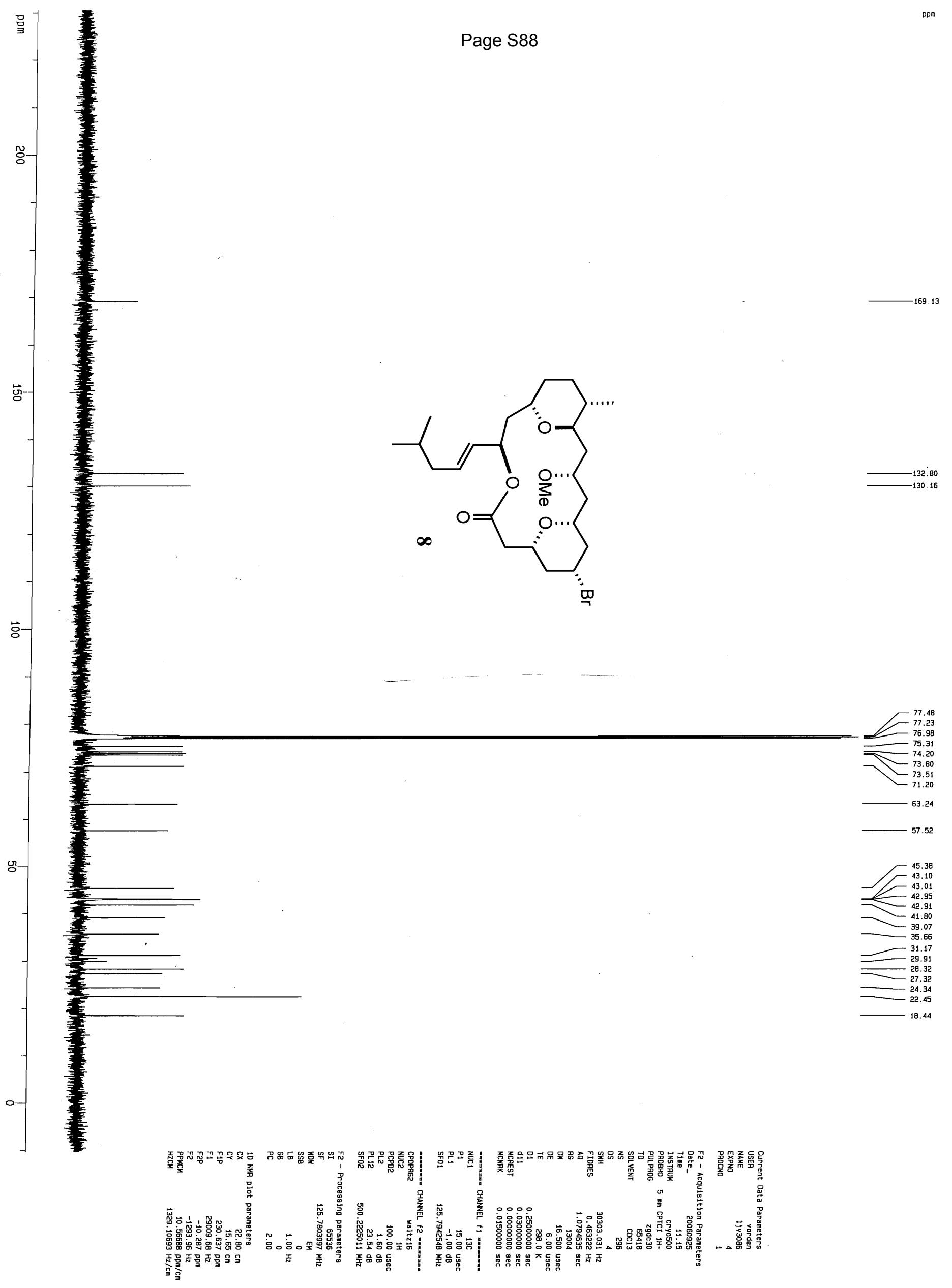



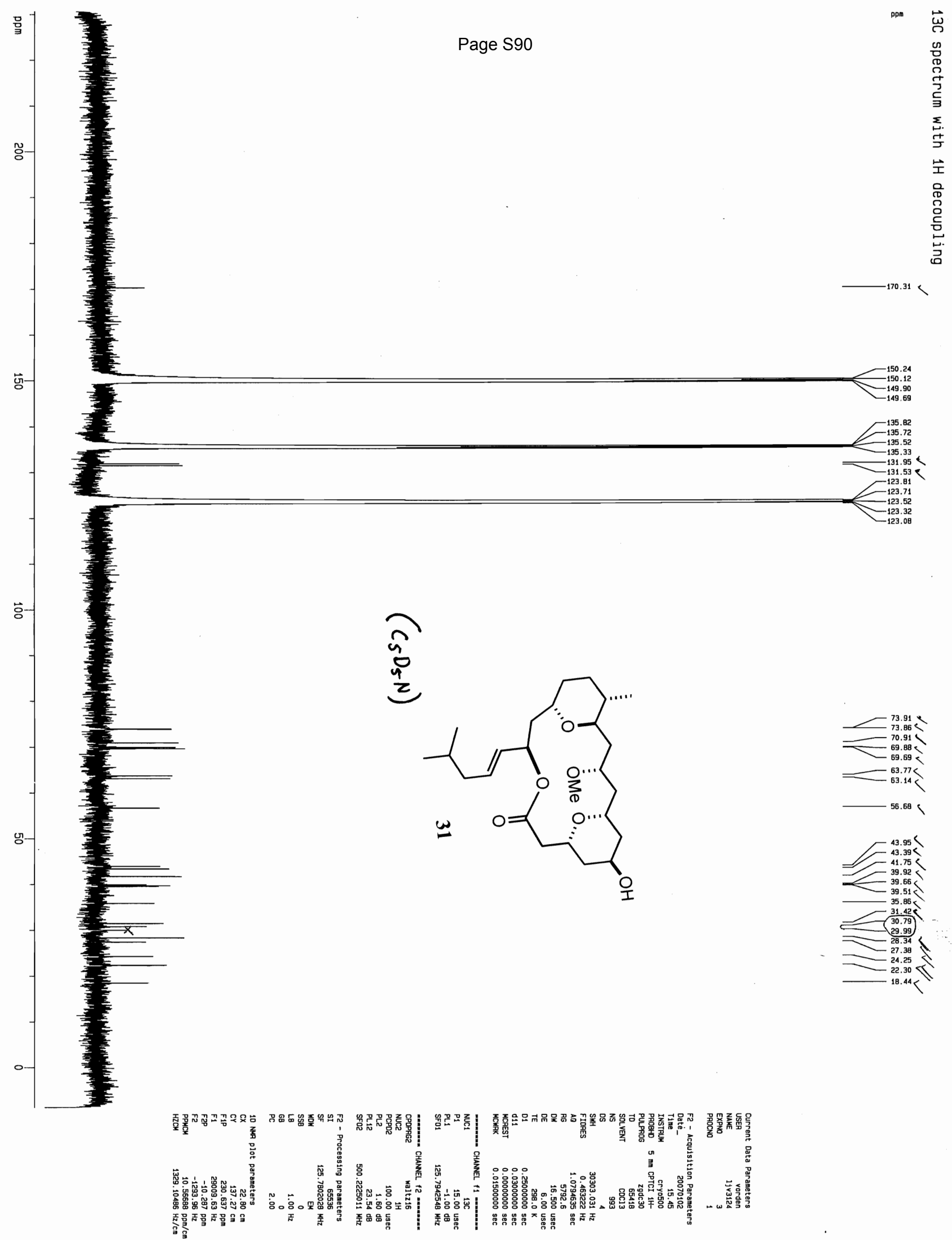

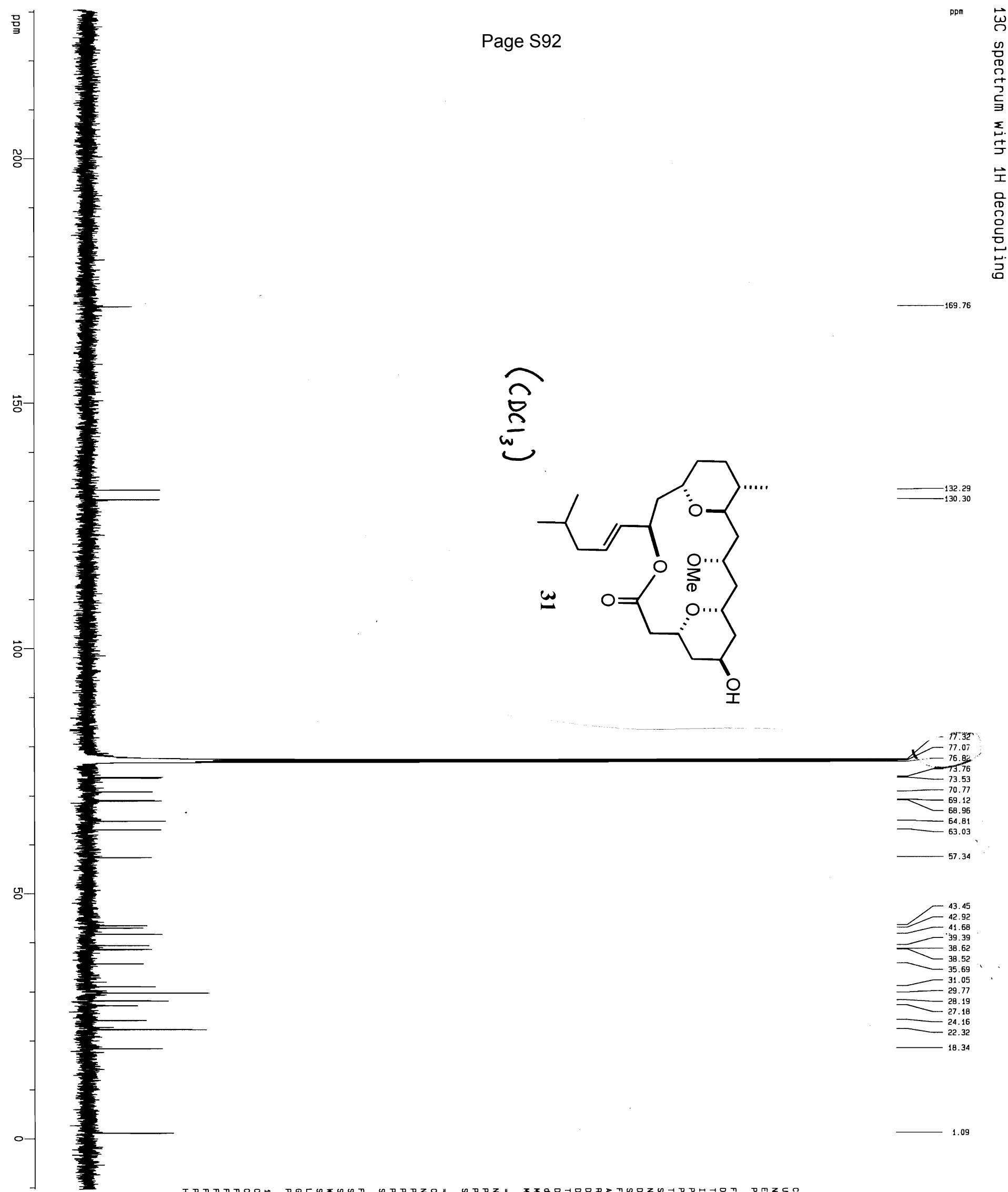


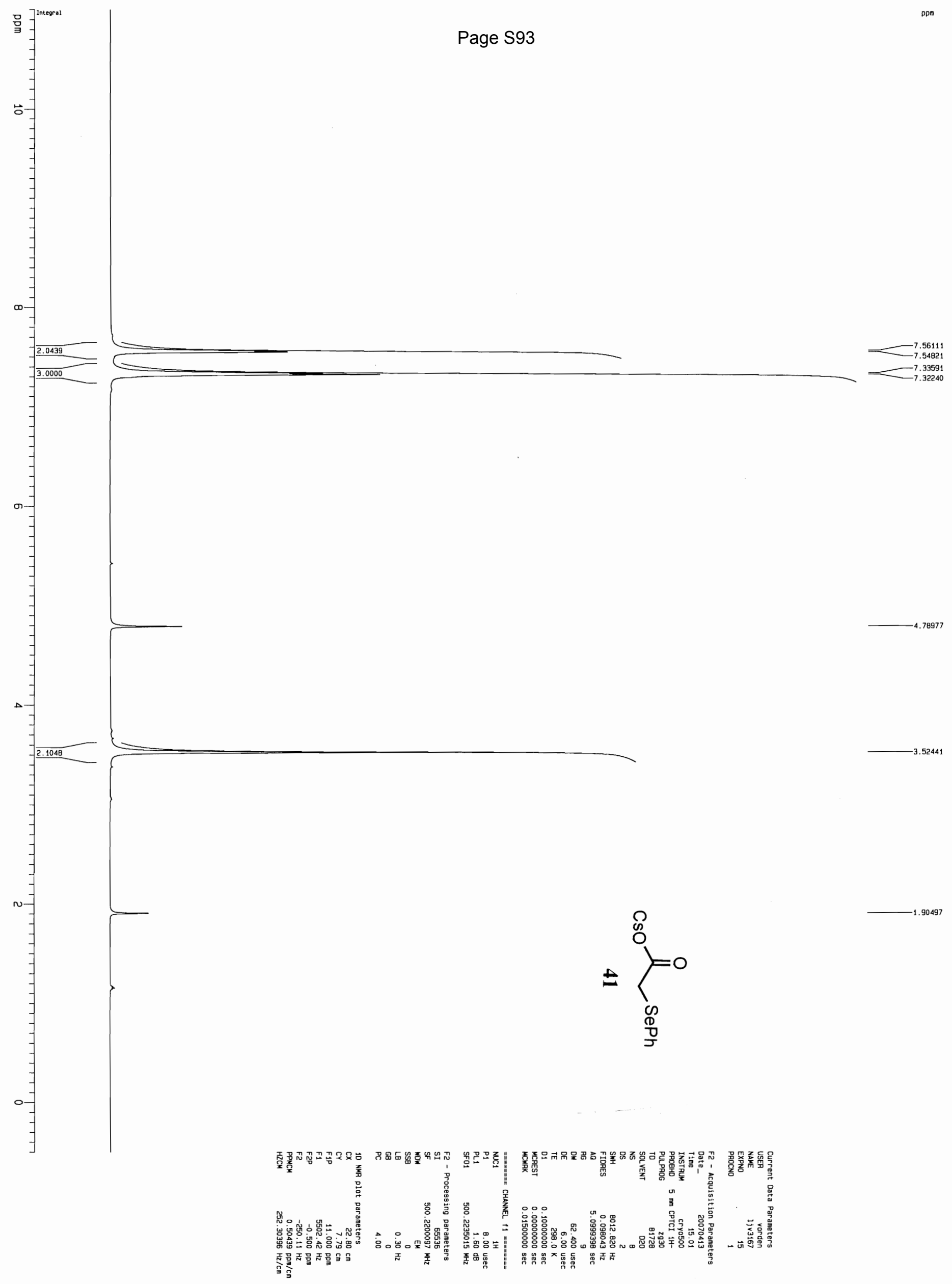




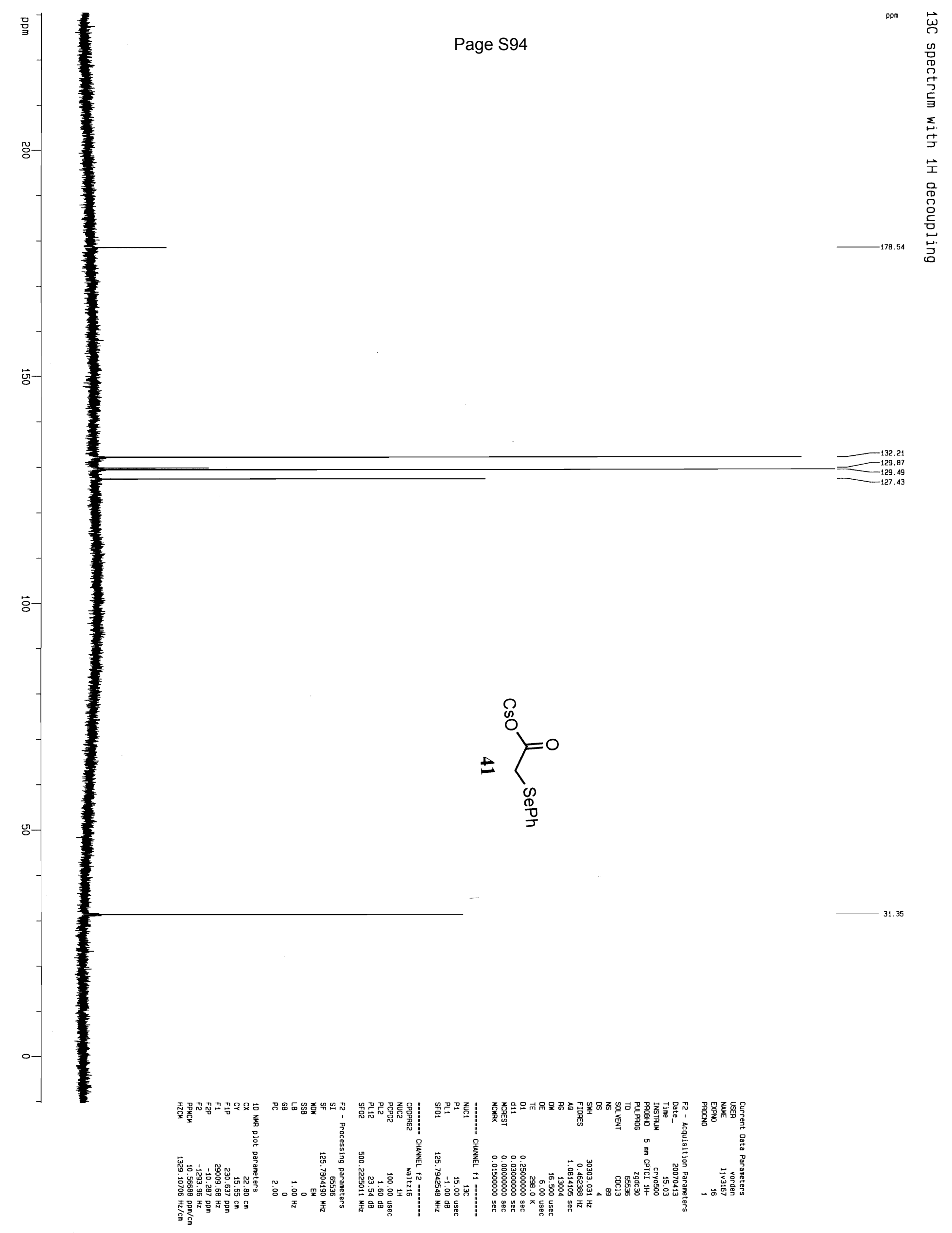




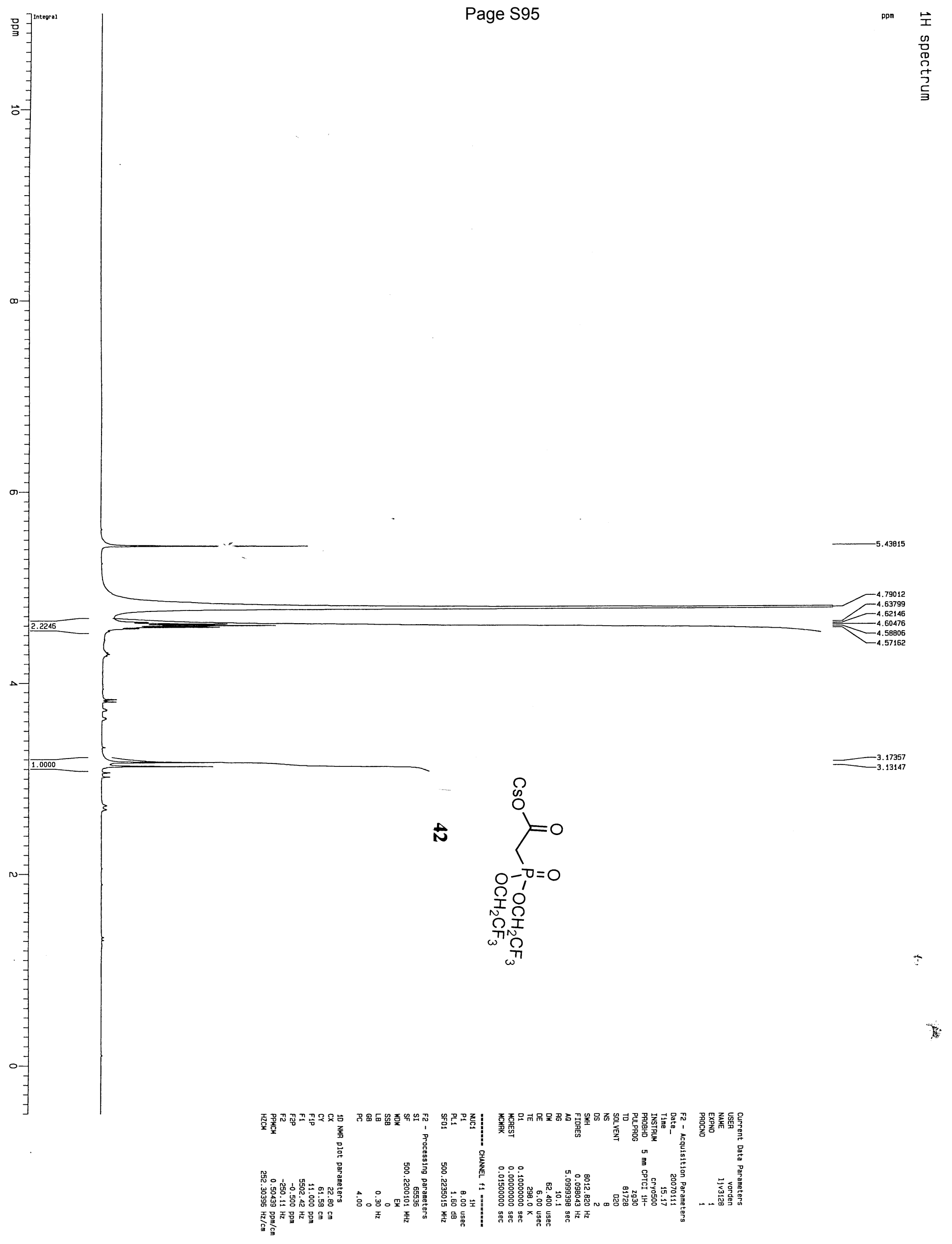



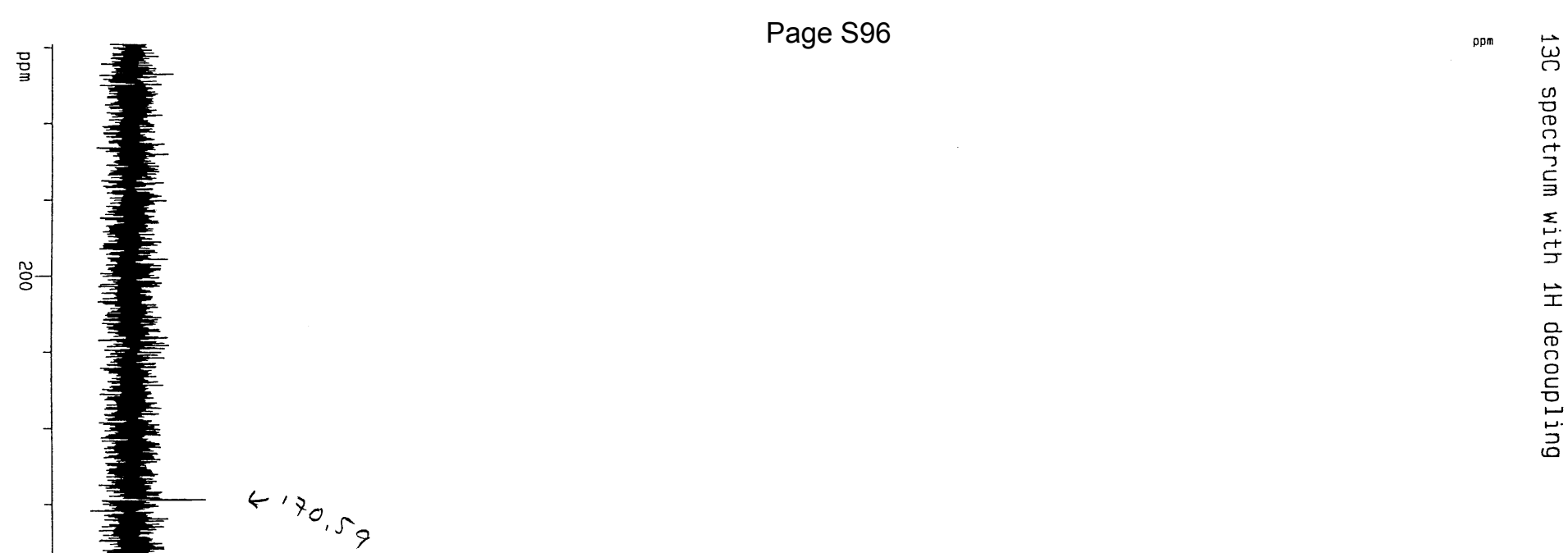

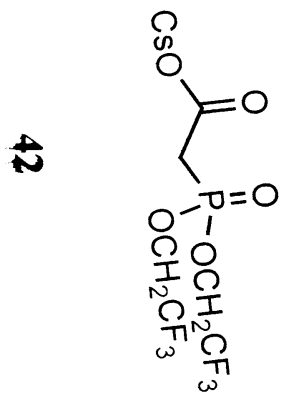

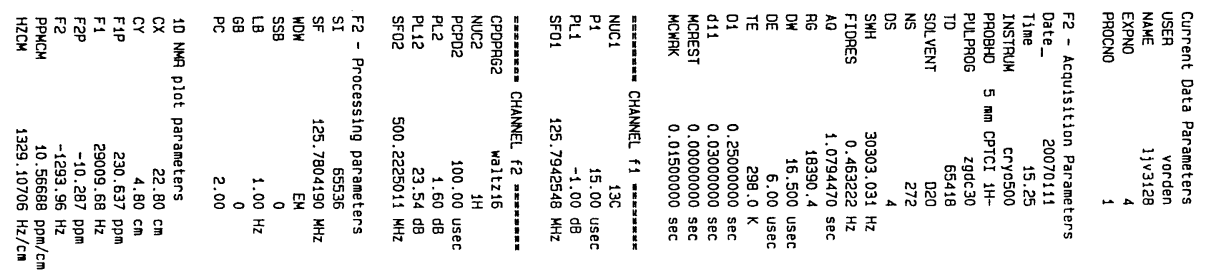




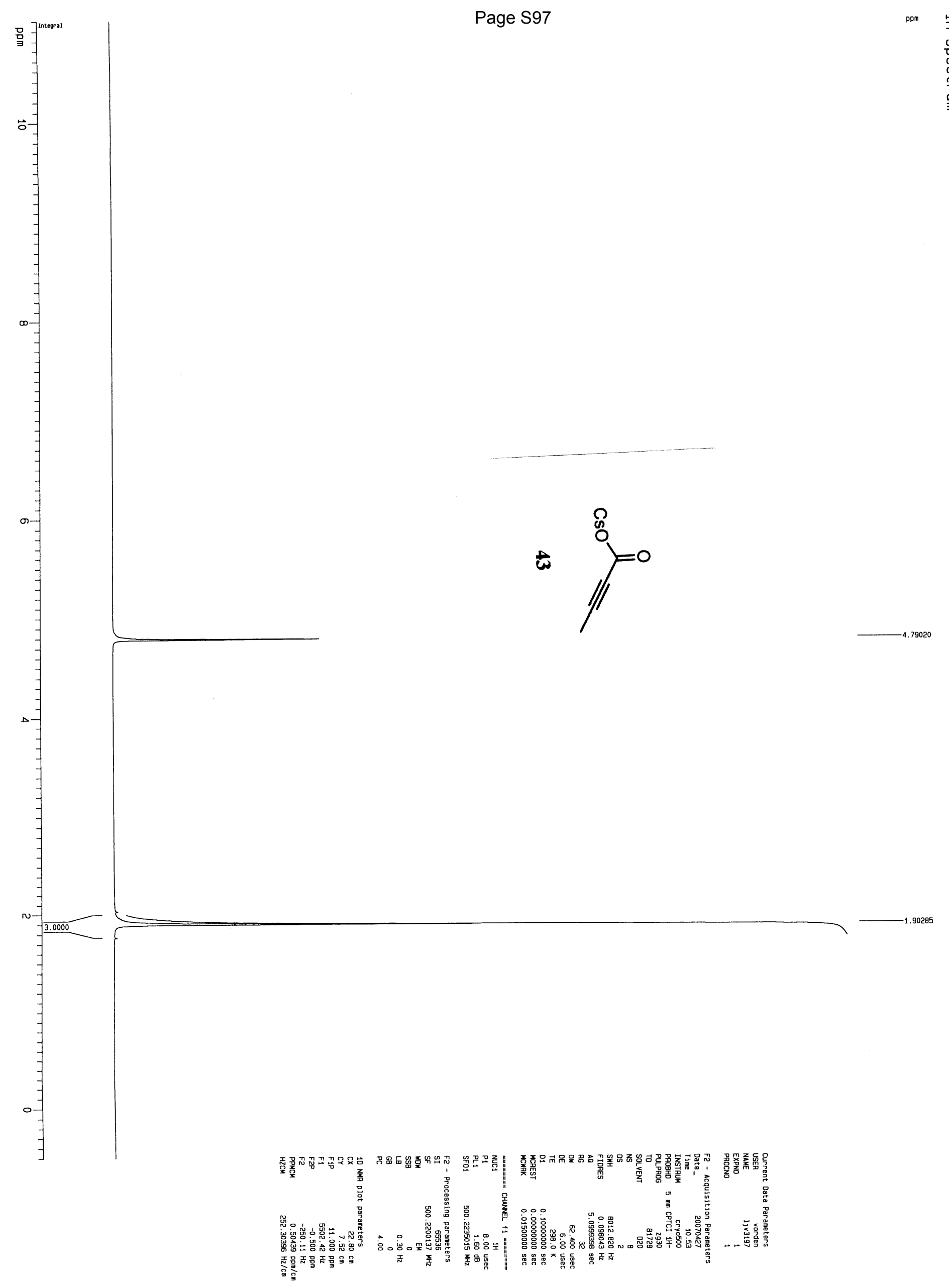



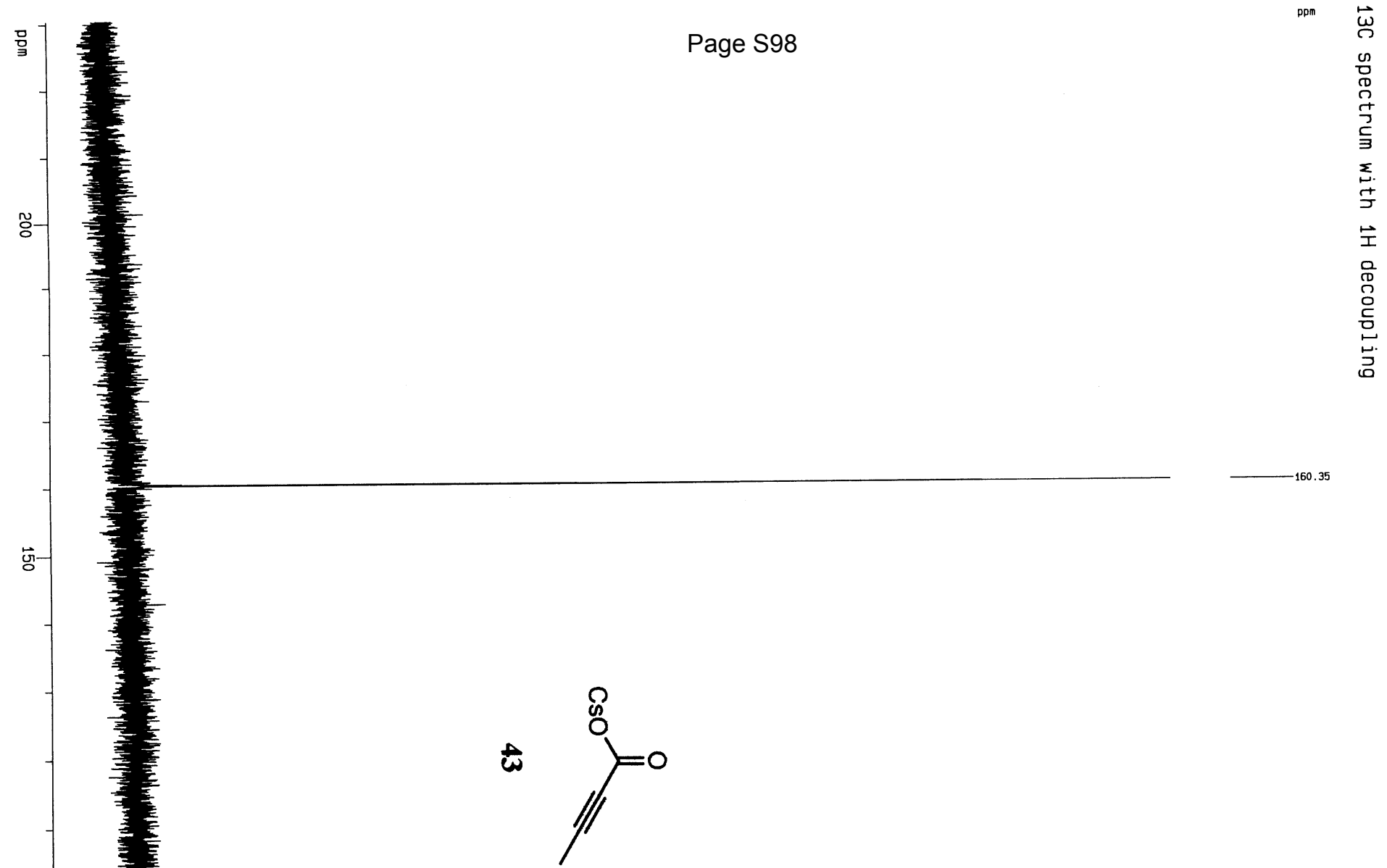

엉 


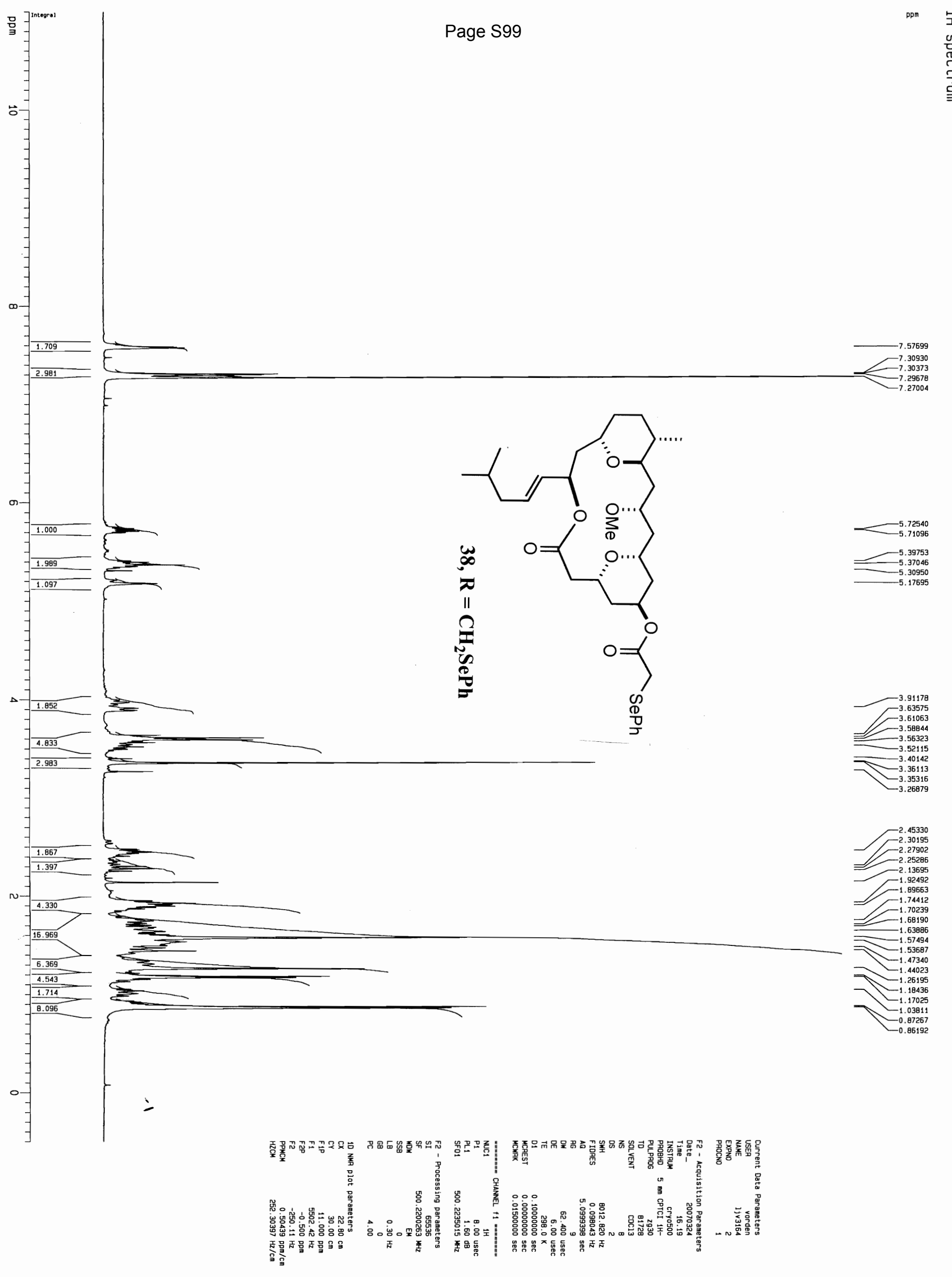



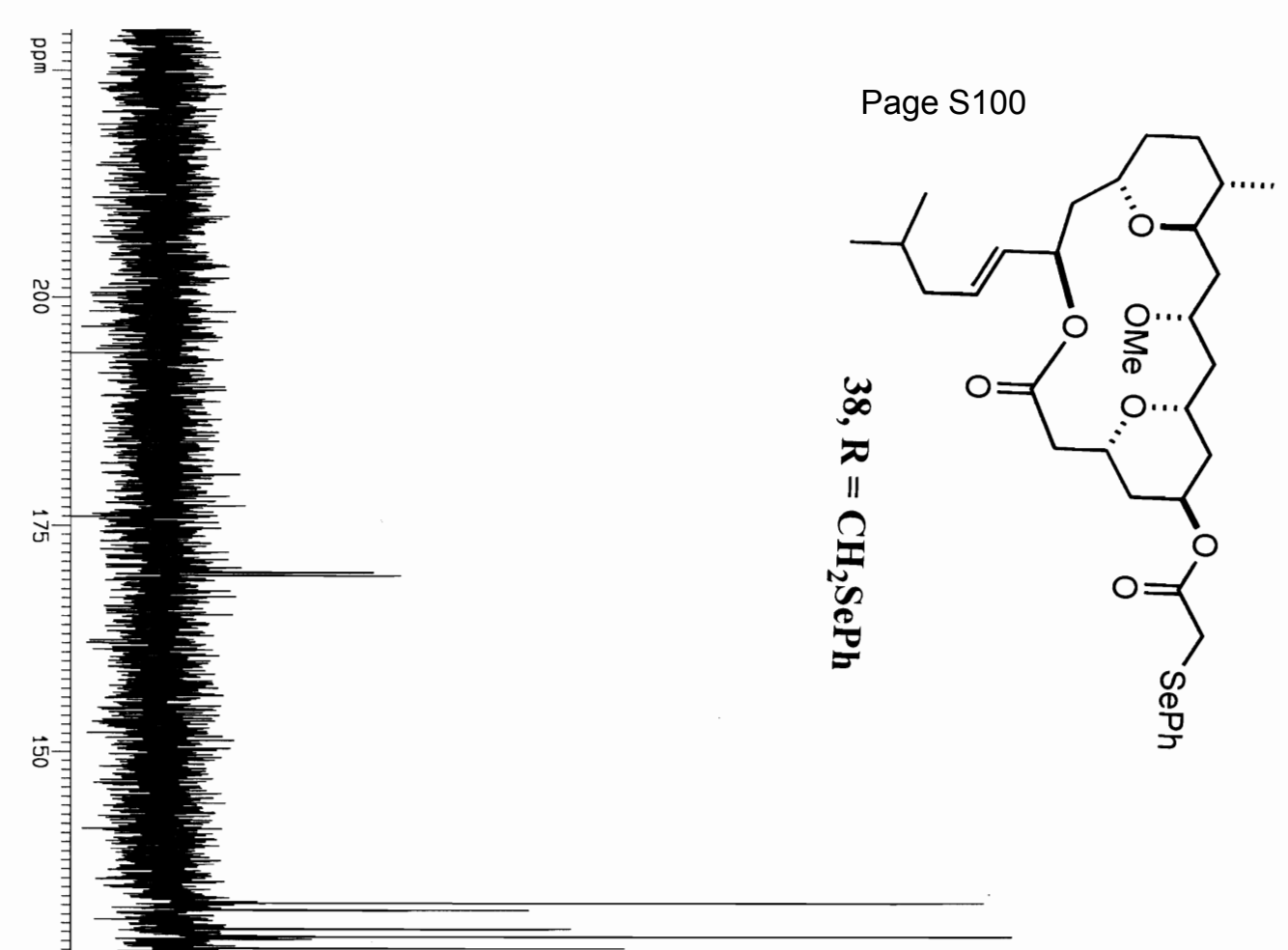

$\overrightarrow{8}$

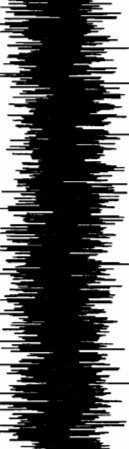

जั

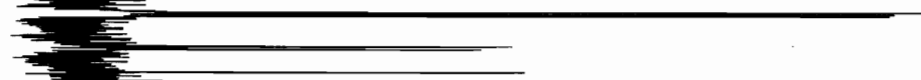

용

䒜

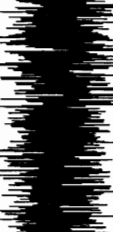

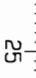

$\Rightarrow$

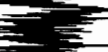




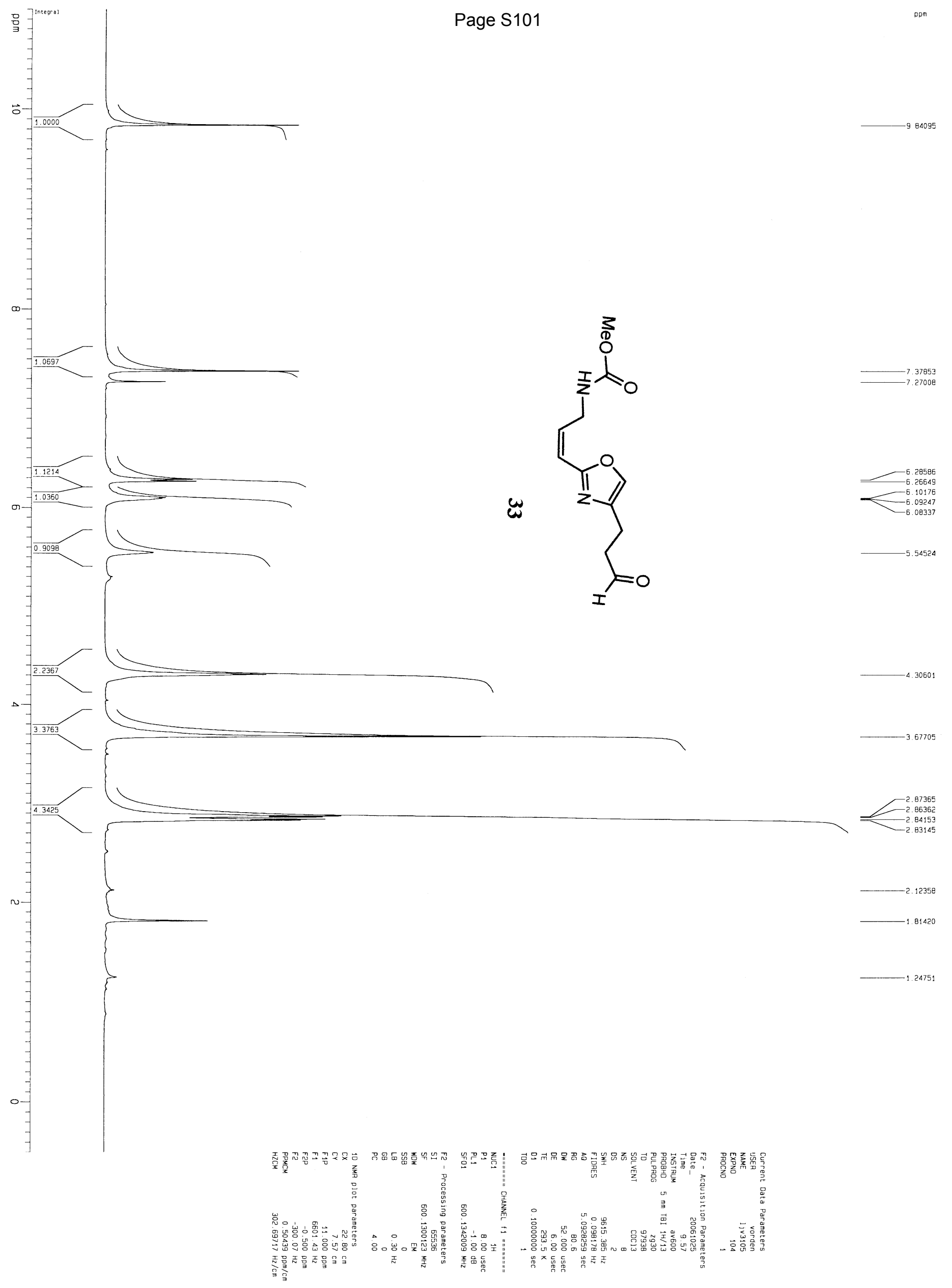




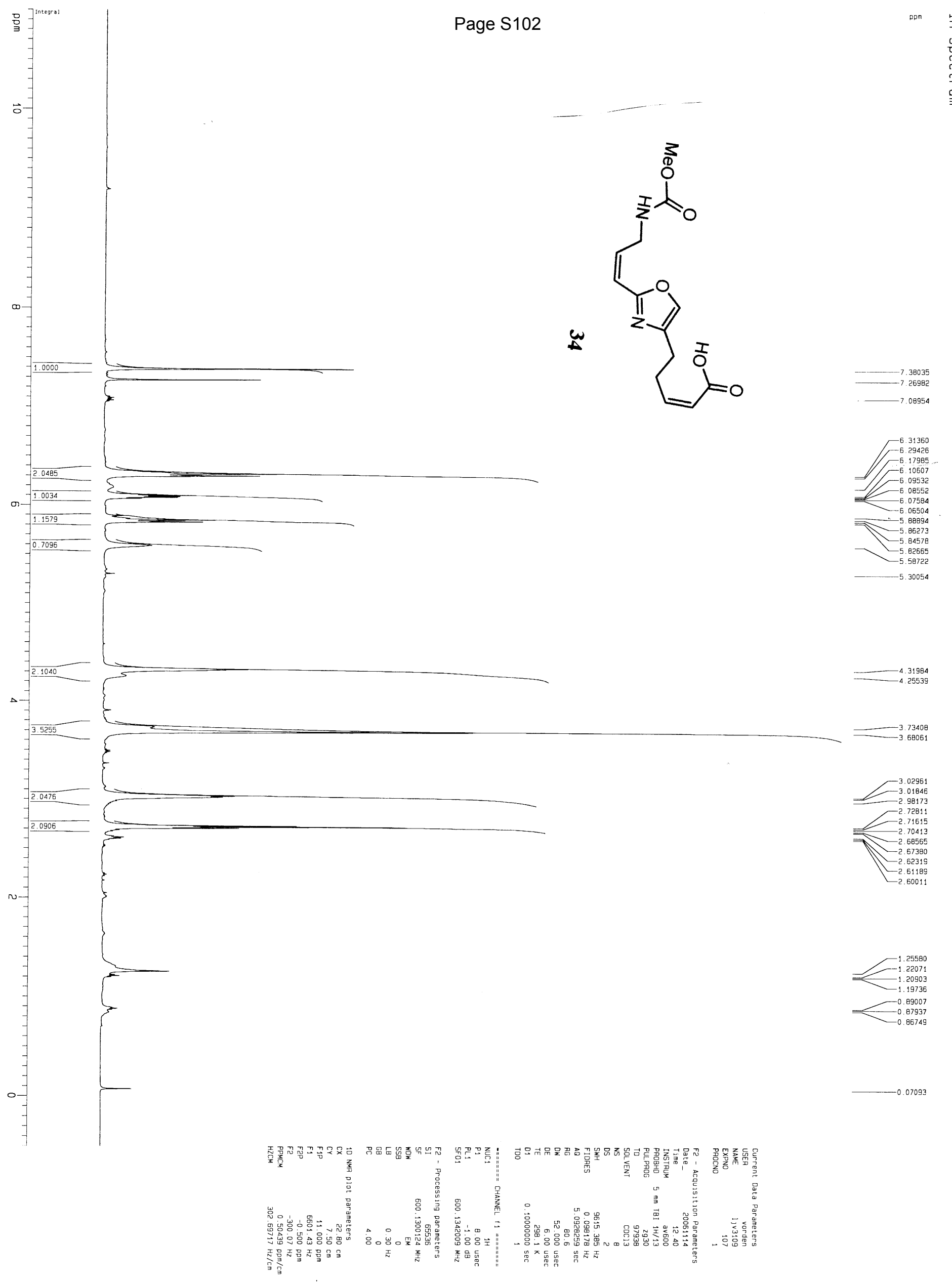




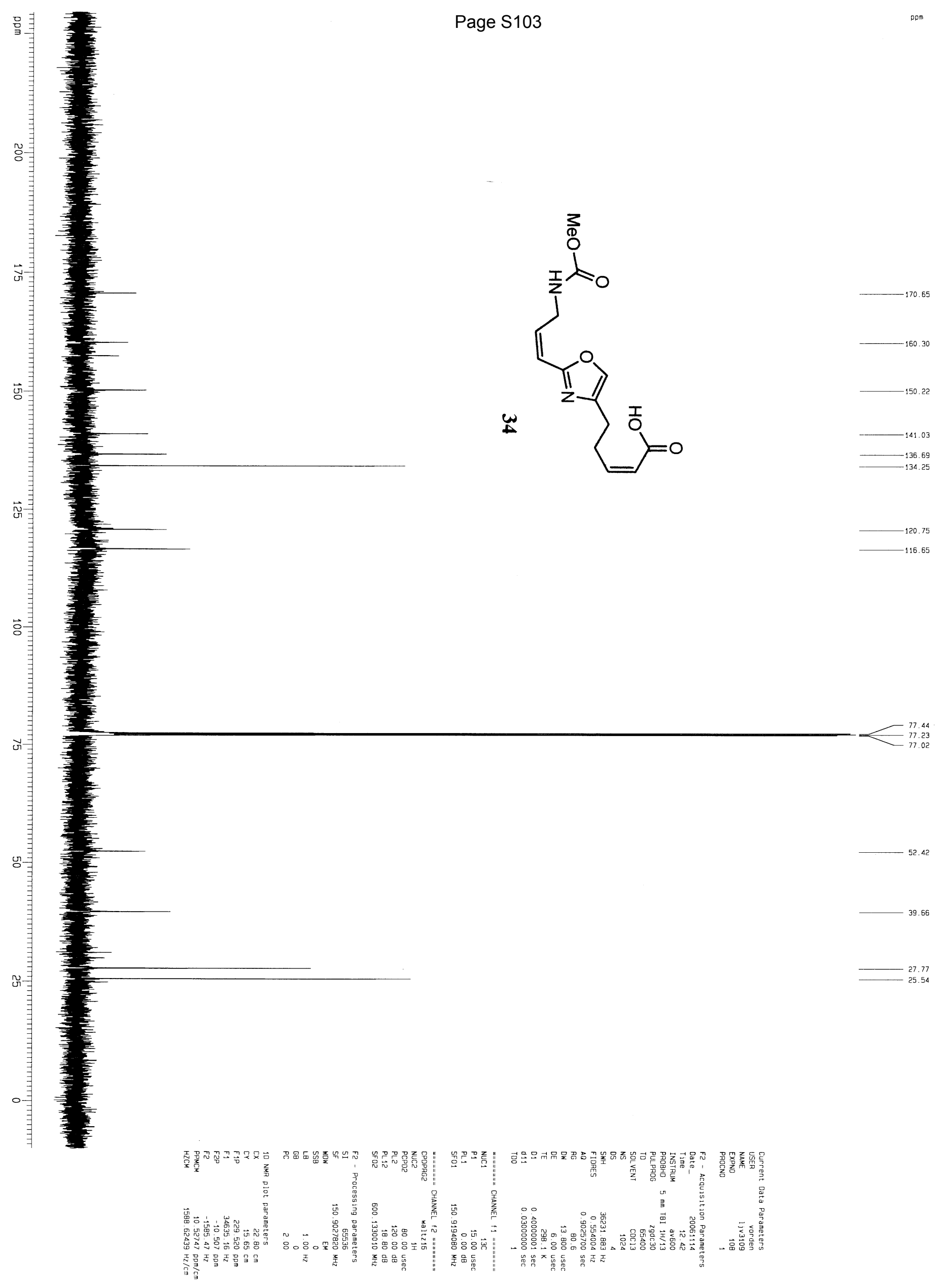




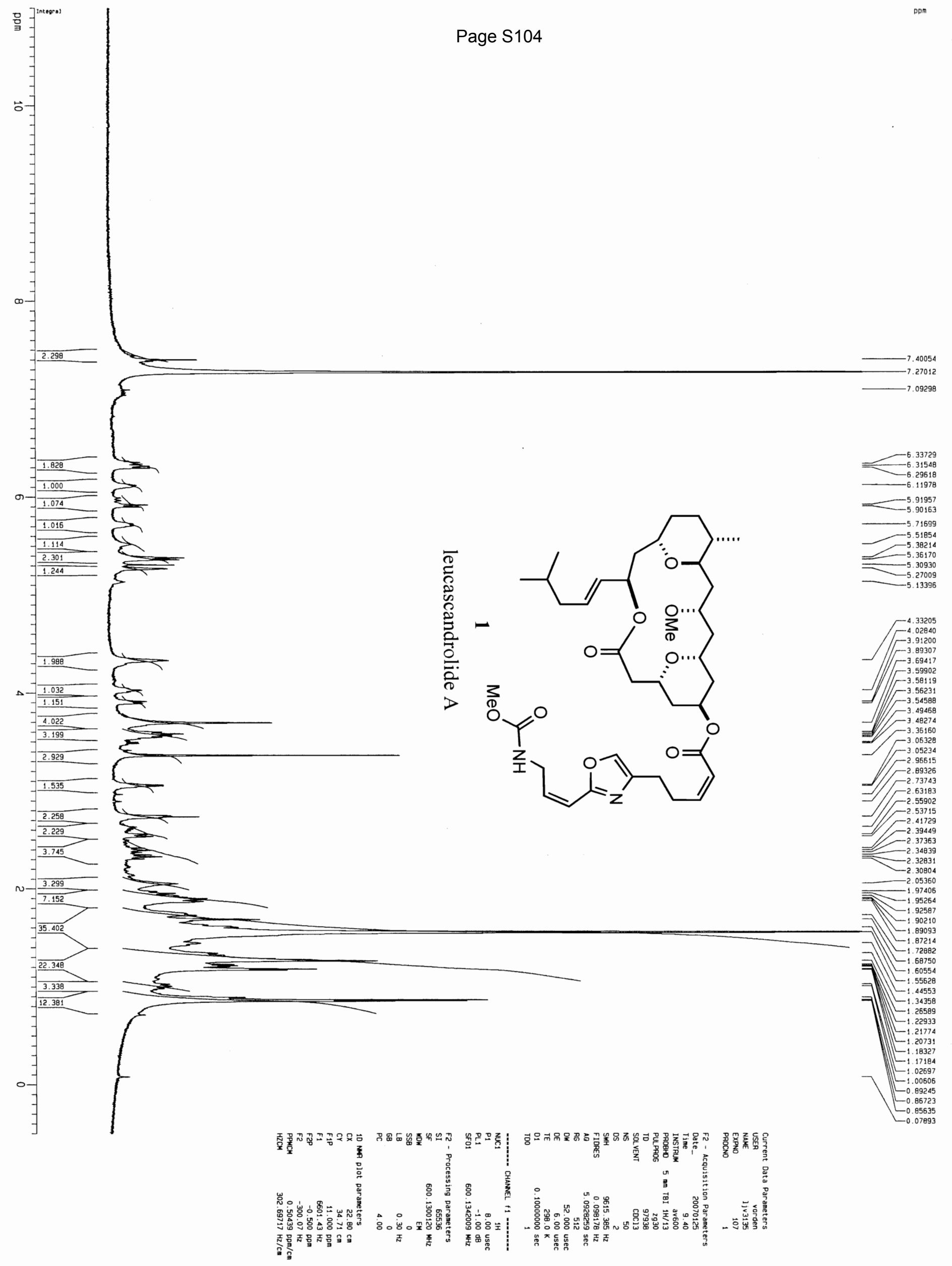




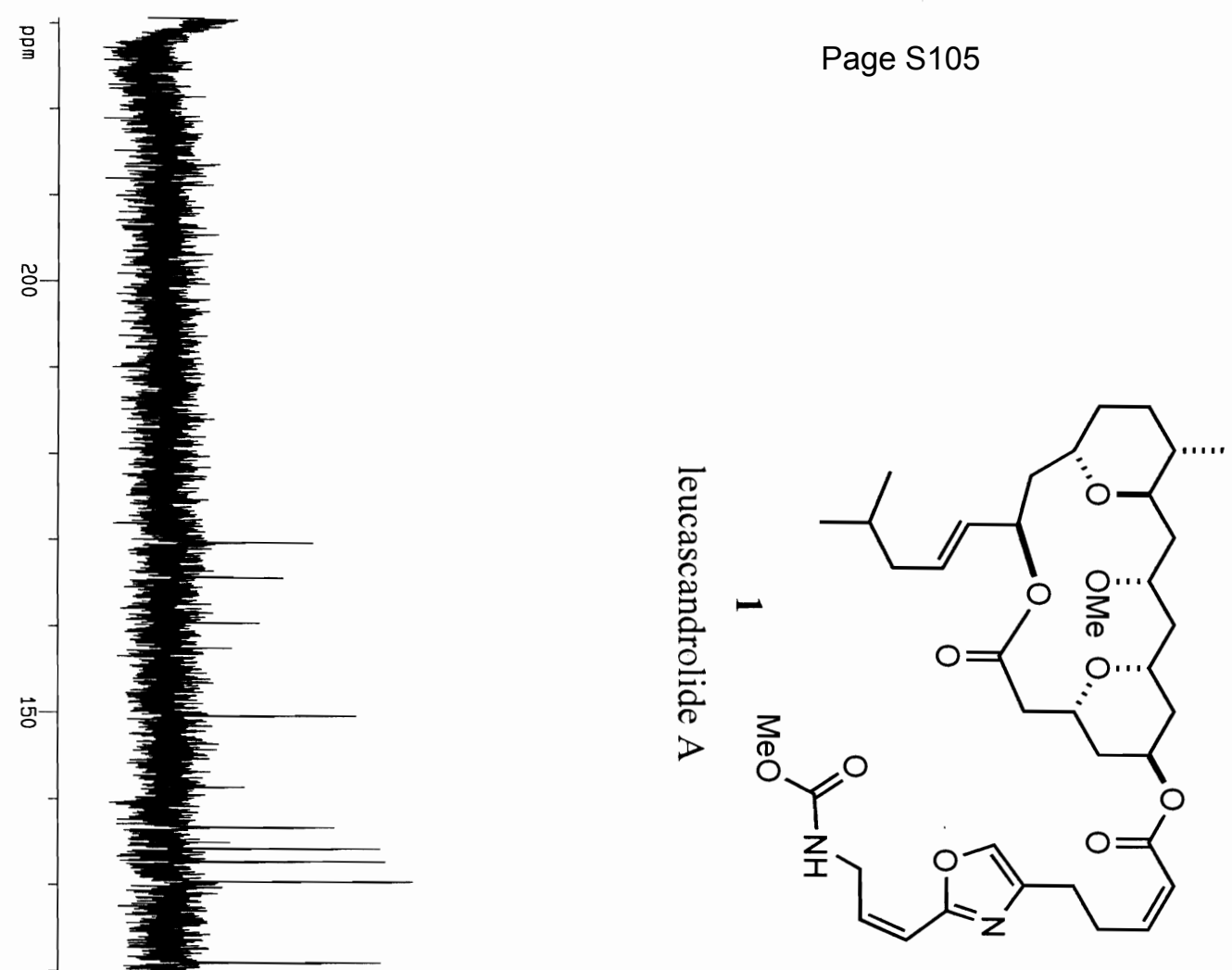

$\sum$

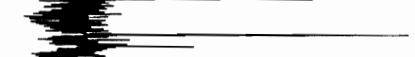

